ex Instituto Archaeologico Universitatis de Rolando Eötvös nominatae

C

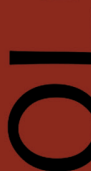

ப

$\varangle$

工

$\cup$

ه

$<$

in

ㄴ
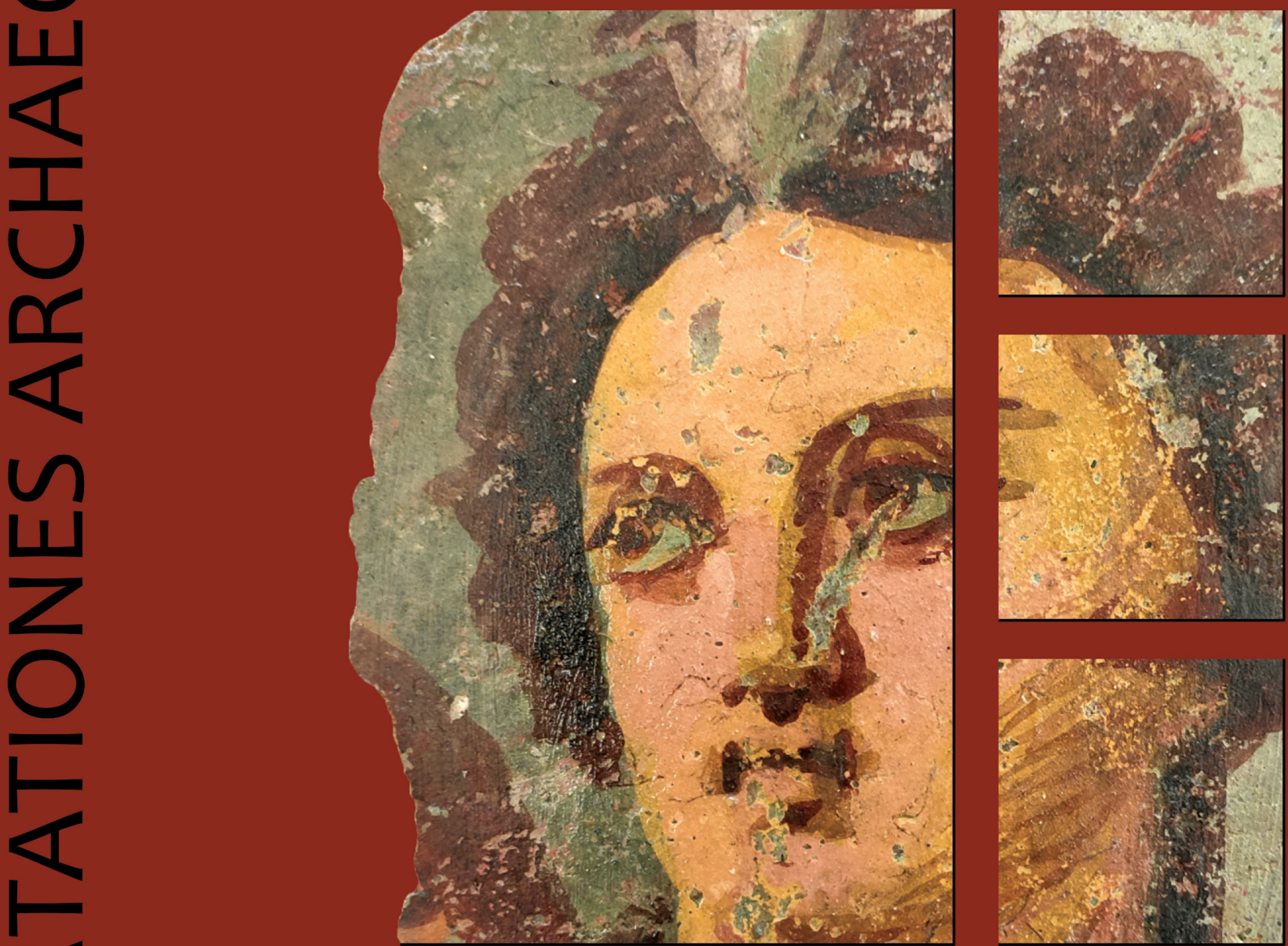

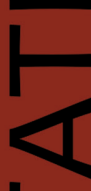

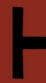

ח

Ш

un

n

0
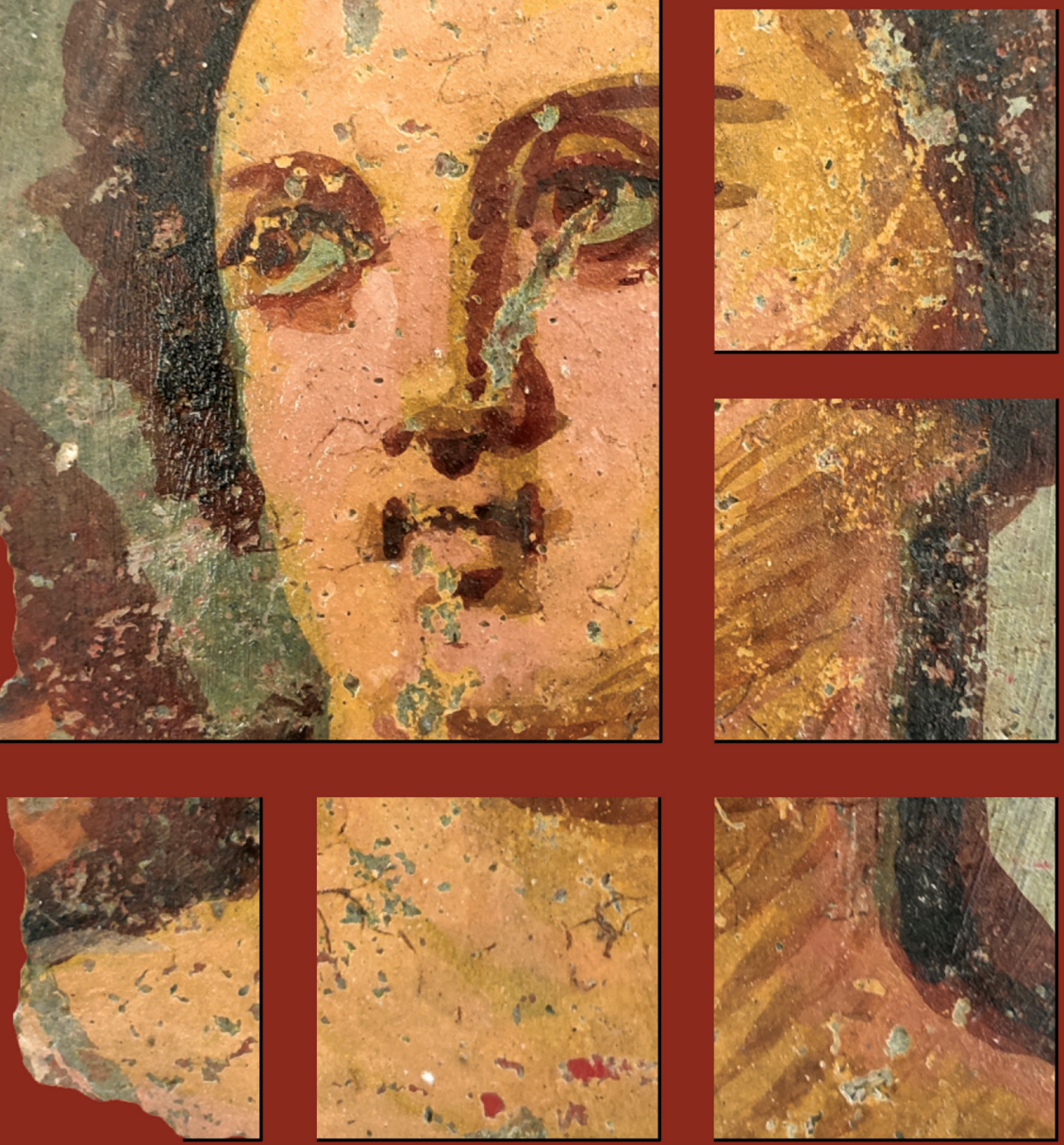

Serp 30 No. 8. 2020 


\section{Dissertationes Archaeologicae ex Instituto Archaeologico}

Universitatis de Rolando Eötvös nominatae Ser. 3. No. 8.

Budapest 2020 
Dissertationes Archaeologicae ex Instituto Archaeologico Universitatis de Rolando Eötvös nominatae Ser. 3. No. 8.

Editor-in-chief:

DÁvid Bartus

Editorial board:

LÁsZló BARTOSIEWICZ

LÁsZLÓ BORHY

ZOLTÁN CZAJLIK

IsTVÁN FELD

GÁBOR KALLA

PÁL RACZKY

MiKLÓS SZABÓ

Tivadar Vida

Technical editor:

Gábor VÁczi

Proofreading:

Szilvia BARTUS-SzÖLLŐsI

Zsófia KondÉ

Márton SZILÁGYI

Aviable online at http://ojs.elte.hu/dissarch

Contact: dissarch@btk.elte.hu

ISSN 2064-4574

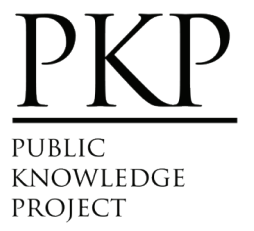

๑ ELTE Eötvös Loránd University, Institute of Archaeological Sciences

Layout and cover design: Gábor Váczi

Budapest 2020 


\section{CONTENTS}

\section{ARTICLES}

Maciej WAWRZCZAK - Zuzana KASENČÁKovÁ

Stará L'ubovña - Lesopark. Late Palaeolithic site and the problems associated with raw material mining

Attila PÉNTEK - Norbert FARAgó

Chipped stone assemblages from Schleswig-Holstein (North Germany) in the collection of the Institute of Archaeological Sciences - ELTE Eötvös Loránd University

Bence Soós 49

Middle Iron Age Cemetery from Alsónyék, Hungary

Tamás Szeniczey - Tamás Hajdu 107

Appendix - Results of the analysis of the Early Iron Age human remains unearthed at Alsónyék, Hungary

Lajos JuHÁsz - József Géza Kiss

Bound in bronze - a Roman bronze statuette of a barbarian prisoner

Csilla SÁRó

The fibula production of Brigetio: clay moulds

\section{Field Reports}

András Füzesi - Knut Rassmann - Eszter BÁnffy - Hajo Hoehler-Brockmann -

Gábor Kalla - Nóra Szabó - Márton SzIlágyi - Pál Raczky

Test excavation of the "pseudo-ditch" system of the Late Neolithic settlement complex at Öcsöd-Kováshalom on the Great Hungarian Plain

Gábor VÁczi - László RupNIK - Zoltán CZAJLIK - Gábor MEsterházy Bettina BitTner - Kristóf FÜlöP - Denisa M. LÖNHARdT - Nóra Szabó

The results of a non-destructive site exploration and a rescue excavation at the site of Pusztaszabolcs-Dohányos völgy északi part

Dávid BArtus - László Borhy - Szilvia JohÁczi - Emese SzÁmadó 181

Excavations in the legionary fortress of Brigetio in 2019 
Dávid BArtus - László Borhy - Emese SzÁmadó - Lajos Juhász - Bence Simon -

Ferenc Barna - Anita Benes - Szilvia Joháczi - Rita Olasz - Melinda Szabó

Excavations in Brigetio in 2020

\section{Thesis Abstracts}

Anett OszTÁs

The settlement history of Alsónyék-Bátaszék.

Complex analysis of its buildings in the context of the Lengyel culture

Csilla SzÁRAz

The region of the Zala and Mura Rivers (Zala County) in the Late Bronze Age.

Late Tumulus and Urnfield period

Ágnes KIRÁly

Human remains unearthed in settlement context from the Late Bronze Age -

Early Iron Age (Reinecke BD-HaB3) Northeastern Hungary

Gergely BóKA

Transformation of settlement history in the Körös Region in the period between the Late Bronze Age and the end of Iron Age

Gabriella G. DeLbó

Pottery production of the settlement complex of Brigetio

Adrienn Katalin BLAY

Die Beziehungen zwischen dem Karpatenbecken und dem Mediterraneum

von der II. Hälfte des 6. bis zum 8. Jahrhundert n. Chr. anhand Schmuckstücken

und Kleidungszubehör

Levente SAMU

293

Die mediterranen Kontakte des Karpatenbeckens in der Früh- und Mittel-

awarenzeit im Licht der Männerkleidung. Gürtelschnallen und Gürtelgarnituren

\section{REviEWS}

Gábor MESTERHÁZY

Czajlik, Z. - Črešnar, M. - Doneus, M. - Fera, M. - Hellmith Kramberger, A. Mele, M. (eds): Researching Archaelogical Landscapes Across Borders - Strategies,

Methods and Decisions for the 21th Century. Graz-Budapest, 2019. 


\title{
Middle Iron Age Cemetery from Alsónyék, Hungary
}

\author{
Bence Soós \\ Institute of Archaeological Sciences \\ ELTE Eötvös Loránd University, \\ Hungarian National Museum \\ Department of Archaeology \\ soos.ben94@gmail.com
}

\begin{abstract}
In 2008 a section of a Middle Iron Age cemetery was unearthed at Alsónyék (Tolna County, Hungary). The 16 graves can be dated broadly to the $5^{\text {th }}$ and maybe the early $4^{\text {th }}$ century BC. The significance of this discovery lies in the diversity of burial customs and grave goods as well as in the fact that sites from this period are relatively rare in Transdanubia. In addition, already these 16 graves make the cemetery the second largest Middle Iron Age graveyard in the region between the Kapos and Sava Rivers.
\end{abstract}

\section{Introduction}

In 2008 and 2009, prior to the construction of the M6 highway, rescue excavations were carried out in the northeastern vicinity of Alsónyék, Tolna County (Southern Hungary). The name of the settlement might sound familiar due to the famous Neolithic complex of AlsónyékBátaszék. ${ }^{1}$ The site Hosszú-dúlő (also known as Alsónyék-Elkerülő 2) is located just a few hundred meters to the east from the former site. The excavations at Hosszú-dúlő were conducted by archaeologists of the Wosinsky Mór Museum, led by János Gábor Ódor. In total, 715 archaeological features came to light representing a time span from the Neolithic to the Migration Period and spreading over an area measuring $11,238 \mathrm{~m}^{2}$. The excavated area comprises of two nearly perpendicular, narrow sections and two curved areas joining them from west (Fig. 1). The latter section yielded almost exclusively burials from the Migration Period, while prehistoric features came to light from the eastern part of the excavated area.

\section{The Middle Iron Age burials}

Up to this date, a mere 16 burials can be assigned to the Middle Iron Age cemetery of Alsónyék. However, there are a number of circumstances indicating that these do not represent the entire graveyard. Firstly, the map of the excavated area (Fig. 1) clearly shows that between the graves located in the northern and western sections there is a vast undisturbed field containing presumably several burials. The possibility of graves located to the east and south cannot be ruled out either. It is worth noting here, that between 2011 and 2014 an international team conducted geophysical prospection on the fields surrounding the excavation area, covering some 30 hectares. Interestingly, besides features of a settlement assigned to the Neolithic

1 Suffice to mention the 94th volume of the Bericht der Römisch-Germanischen Kommission that was devoted entirely to this particular site. 
Sopot culture, the magnetogram clearly shows five circular ditches indicative of burial mounds of yet indeterminable age. ${ }^{2}$ These are located at different distances from the excavated Iron Age burials. Secondly, there are some rectangular pits similar to graves, yet without human remains or artefacts. These raise the question whether we might count with, grave robbery or plundering, the possibility of which will be addressed later in this paper.

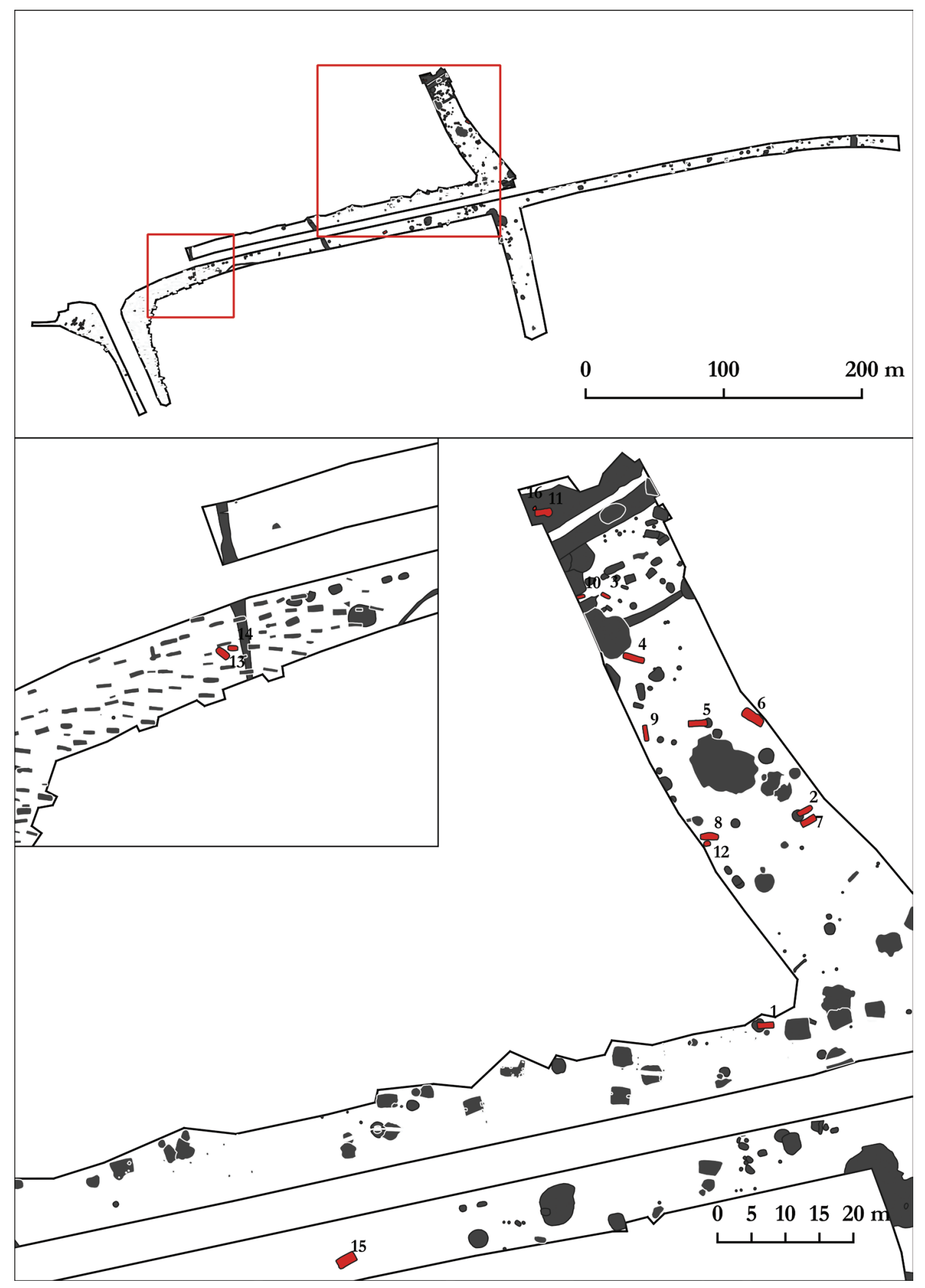

Fig. 1. Map of the excavated area at Alsónyék-Hosszú dűlő. 


\section{Catalogue of the Middle Iron Age Burials}

\section{Grave no. 1 (Feature no. 183)}

Grave pit:

Shape: Shallow, rectangular pit with rounded corners. Dimensions: 240 by $89 \mathrm{~cm}$, relative depth: $20 \mathrm{~cm}$. Orientation: E-W (98 $)$. Fill: Dark brown humus mixed with clay.

Burial rite: Inhumation

\section{Description:}

Skeleton lying in stretched position on its back with the skull directed west. The bones are in relatively good condition. The skull leans slightly to the left. The right forearm is placed onto the chest, the bones of the hand are missing. The left arm is bent so that the hand is at the left shoulder. The legs are stretched. The length of the skeleton is $157 \mathrm{~cm}$ (Fig. 2).

Position of the grave goods:

There was one earring on each side of the skull (1-2). Around the neck there were several yellow, blue, white and green glass paste and amber beads. There were four fibulae on chest, one on the left collarbone, one on the left side of the chest, one additional fibula came to light near the right forearm and another piece next to the right collarbone. There was a spindle whorl next to the left elbow. There was an iron knife lying along the right humerus pointing towards the legs. Next to the left el-

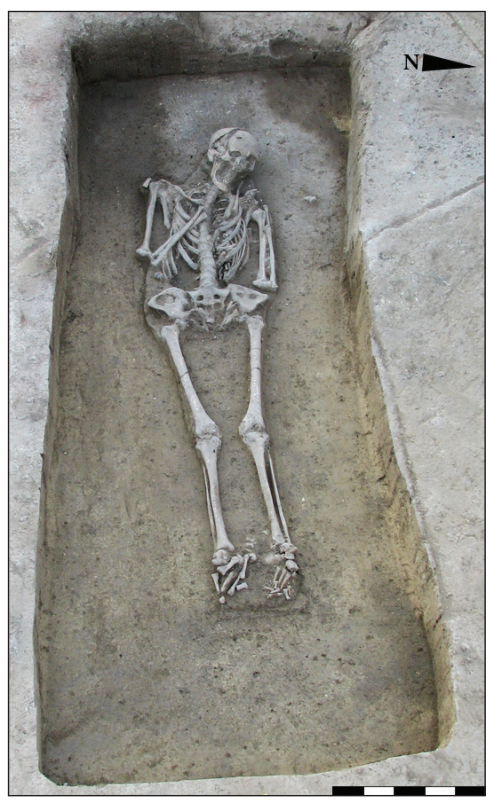

Fig. 2. Photo of Grave no. 1. bow a piece of a thin bronze wire was found.

Grave goods:

1. Earring. Small, open bronze ring made of wire. D: $1.3 \mathrm{~cm}$ (Inv. no.: M6-2009.A2.183.1) (Fig. 3.1).

2. Earring. Small, open bronze ring with overlapping ends made of wire. D: 1.2 cm (Inv. no.: M6-2009. A2.183.8) (Fig. 3.2).

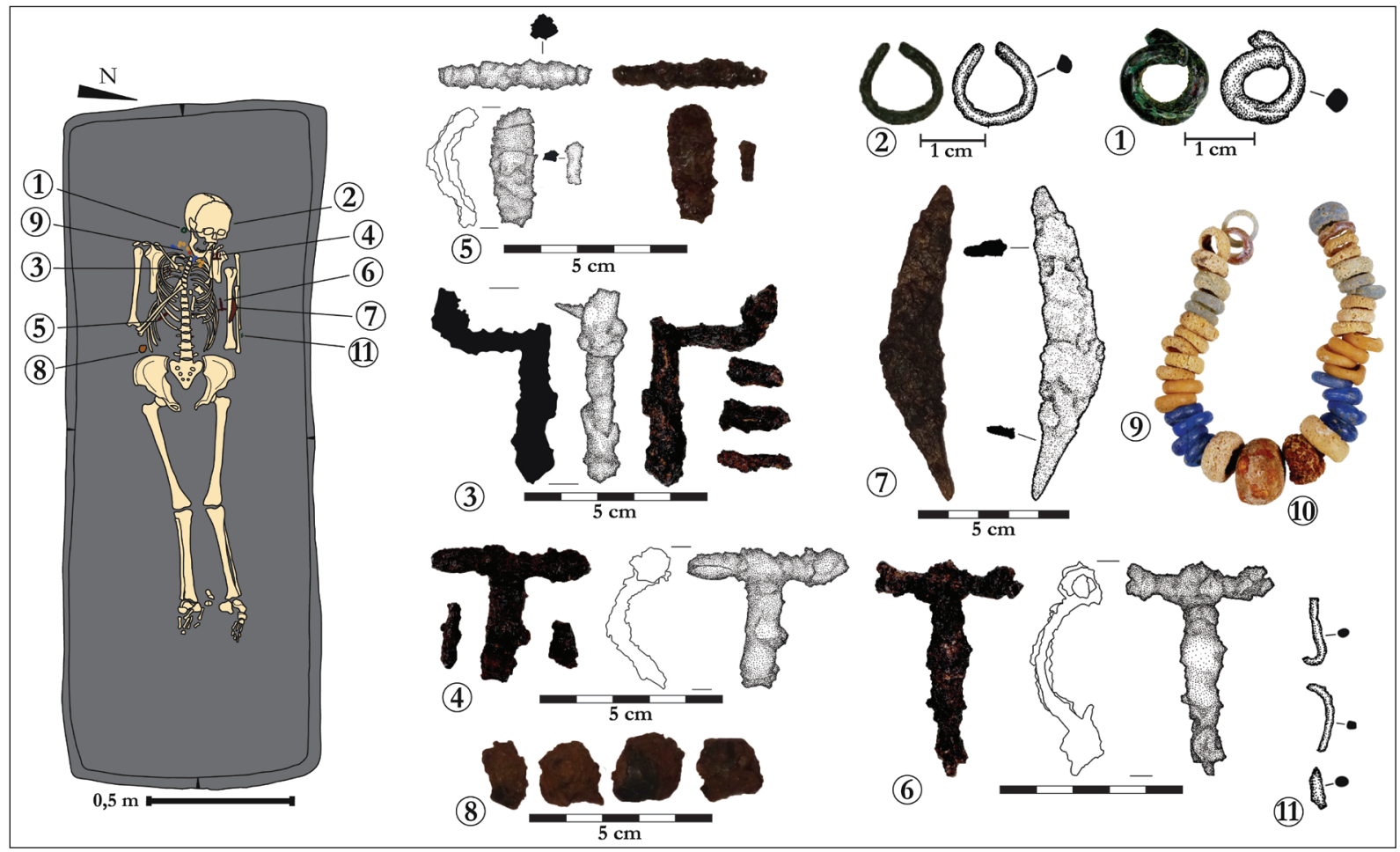

Fig. 3. Grave no. 1. 
3. Iron fibula. Five highly corroded fragments of a crossbow-shaped fibula made of iron. The foot's cross section is of rectangular shape. The smaller fragments are not depicted. Length of the largest fragment: $5.2 \mathrm{~cm}$. (Inv. no. M6-2009.A2.183.3) (Fig. 3.3).

4. Iron fibula. Two highly corroded fragments of a crossbow-shaped fibula made of iron. The smaller fragments are not depicted. Length of the largest fragment: $3.8 \mathrm{~cm}$. (Inv. no. M6-2009.A2.183.4) (Fig. 3.4).

5. Iron fibula. Four highly corroded fragments of a crossbow-shaped fibula made of iron. The smaller fragments are not depicted. The width of the spring construction: $4.2 \mathrm{~cm}$ (Inv. no. M6-2009.A2.183.5) (Fig. 3.5).

6. Iron fibula. Four highly corroded fragments of a crossbow-shaped fibula made of iron. The smaller fragments are not depicted. Length of the fibula: $5.7 \mathrm{~cm}$; the width of the spring construction: $3.8 \mathrm{~cm}$. (Inv. no. M6-2009.A2.183.6) (Fig. 3.6).

7. Iron knife. Short curved piece with tang. L: $10.2 \mathrm{~cm}$ (length of the blade: $8.1 \mathrm{~cm}$ ) (Inv. no. M6-2009.A2.183.9) (Fig. 3.7).

8. Spindle whorl. Fragmented, made of burnt clay. (Inv. no. M6-2009.A2.183.7) (Fig. 3.8).

9. Glass paste beads of various colours (48 pieces). D: 0.6-0.8 cm (Inv. no. M6-2009.A2.183.2) (Fig. 3.9).

10. Amber beads (3 pieces). D: 0.6-1.0 cm. (Inv. no. M6-2009.A2.183.2) (Fig. 3.10).

11. Fragments of an object made of bronze wire (3 pieces). (Inv. no. M6-2009.A2.183.10) (Fig. 3.11).

\section{Grave no. 2 (Feature no. 203)}

\section{Grave pit:}

The grave was slightly disturbed during the removal of the humus layer. Shape: Shallow, rectangular pit with rounded corners. A posthole of relatively large diameter was dug into the NE end of the pit. Dimensions: 236 by $88 \mathrm{~cm}$, relative depth: $10 \mathrm{~cm}$. Orientation: SW-NE $\left(304^{\circ}\right)$. Fill: Dark brown humus mixed with clay.

Burial rite: Inhumation

Description:

The disturbance mainly affected the area of the upper body and the skull of the deceased. The skeleton was lying in supine position. Large parts of the cranium are missing, only the jaw remained. Due to past disturbance, the ribs, most vertebrae, the bones of the hands and the right femur
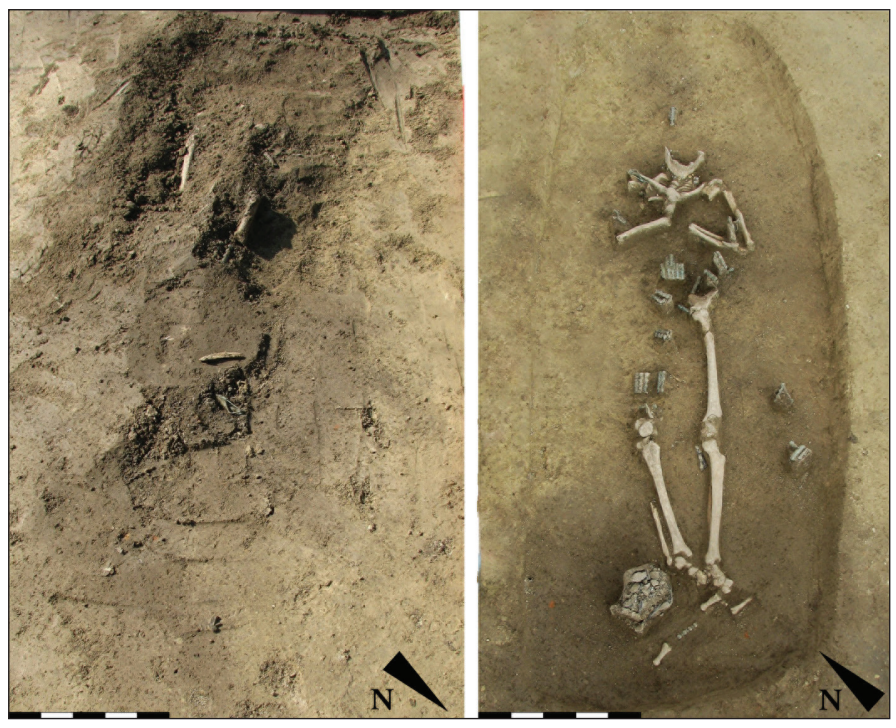

Fig. 4. Photos of Grave no. 2. were completely missing. Nevertheless, the remaining bones of the arms suggest that the arms were bent to the chest. The pit is slightly deeper around the legs. The legs are stretched. The length of the skeleton was $138 \mathrm{~cm}$ (Fig. 4).

Position of the grave goods:

The glass paste beads were scattered around the jaw. There was one fibula at the distal end of the right collarbone, another piece near the right elbow, and two additional bronze fibulae near the left elbow. Some green discolouration on the left collarbone suggests that one of the fibulae might have been located there originally. In the area of the pelvis five segments of the astragal belt were found. Further articles were scattered around the remaining fragments of the pelvis and the right femur. There were a few segments near the left knee. A small grey pot was located near the feet of the deceased.

Grave goods:

1. Hand-made pot. (Inv. no. M6-2009.A2.203.1) Material: Ceramic, finely tempered with sand and grained ceramic. Both the outer and inner surface is grey. The outer surface is smoothed. Shape: Outcurving rim, conical neck and conical lower part with flat bottom. Dimensions: H: $14.4 \mathrm{~cm}$; DR: $9.5 \mathrm{~cm}$; DB: $6.0 \mathrm{~cm}$. (Fig. 5.1).

2. Bronze fibula. Certosa Type $\mathrm{V}$. The bow with a slight longitudinally running edge has two transversal ribs on either ends. The fibula has a three-coil spring on its left side. The triangular foot ends in a flat knob, its trapezoidal catch-plate is still holding the pin. L: 6.7 cm; FL: 2.4 cm. (Inv. no. M6-2009.A2.203.2) (Fig. 5.2). 
3. Bronze fibula. Certosa Type V. The bow with a slight longitudinally running edge has two transversal ribs on either ends. The fibula has a three-coil spring on its right side. The triangular foot ends in a flat knob, its trapezoidal catch-plate is still holding the pin. L: $5.6 \mathrm{~cm}$; FL: $1.8 \mathrm{~cm}$. (Inv. no. M6-2009.A2.203.3) (Fig. 5.3).

4. Bronze fibula. Certosa Type V. The bow with a slight longitudinally running edge has two transversal ribs on either ends. The fibula has a three-coil spring on its left side. The triangular foot ends in a flat knob, its trapezoidal catch-plate is not holding the pin. L: $6.7 \mathrm{~cm}$; FL: $2.3 \mathrm{~cm}$. (Inv. no. M6-2009.A2.203.4) (Fig. 5.4).

5. Bronze fibula. Certosa Type V. The bow with a slight longitudinally running edge has two transversal ribs on either ends. The fibula has a three-coil spring on its right side. The triangular foot decorated with six incised point-circle motifs ends in a flat knob, its trapezoidal catch-plate is holding the pin. L: $5.3 \mathrm{~cm}$; FL: 1.8 cm. (Inv. no. M6-2009.A2.203.5) (Fig. 5.5).

6. Belt buckle. Belt buckle made of bronze with rectangular plate and three loops bearing twisted decoration. The plate has four transversal threads. There are two grooves running along the edges on either sides. The edge opposite to the loops is decorated with oblique grooves. This decoration resembles the one visible on the loops. L: $5.8 \mathrm{~cm}$; W: $2.3 \mathrm{~cm}$. (Inv. no. M6-2009.A2.203.7) (Fig. 5.6).

7. Belt segments. Segments of an astragal belt made of bronze. They are segments comprising four calottes separated by rectangular bars decorated with incised horizontal lines. There is a loop under each calotte. There were 35 segments among the finds in the grave. L: $5.8 \mathrm{~cm}$; W: $1.2 \mathrm{~cm}$. (Inv. no. M6-2009.A2.203.8-42) (Fig. 5.7).

8. Various glass paste beads. Yellow flat beads of relatively poor quality (20 pieces). Blue flat beads ( 21 pieces). One yellow bead decorated with white and blue eye motifs. Furthermore, 14 pieces of fragmented beads. D: 1.0-1.1 cm. (Inv. no. M6-2009.A2.203.6) (Fig. 5.8).

9. Amber beads (2 pieces). Highly corroded. D: $1.0 \mathrm{~cm}$. (Inv. no. M6-2009.A2.203.6) (Fig. 5.9).

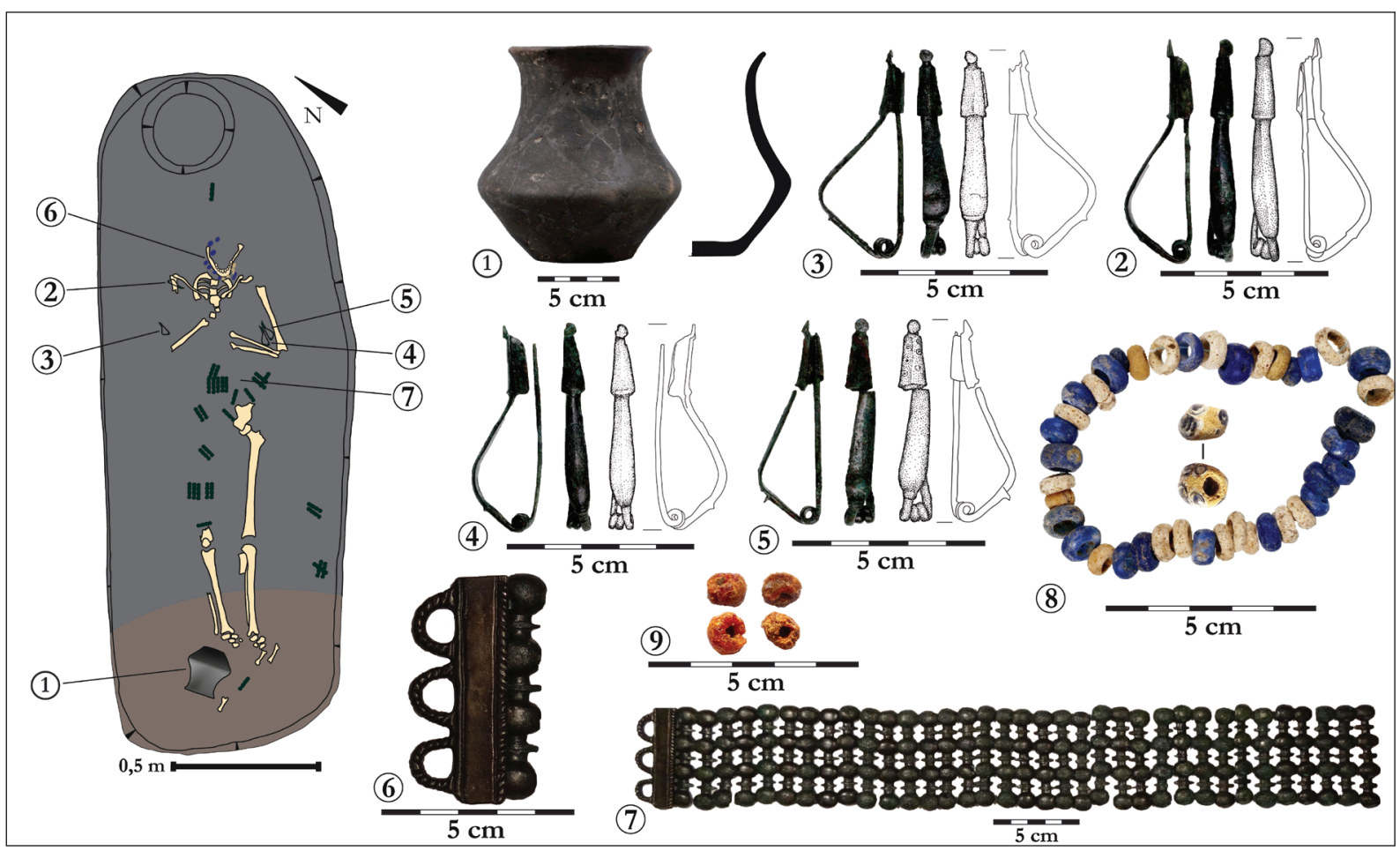

Fig. 5. Grave no. 2

Grave no. 3 (Feature no. 216)

Grave pit:

The grave was heavily disturbed. Shape: Shallow, rectangular pit with rounded corners. Dimensions: 142 by $53 \mathrm{~cm}$, relative depth: $16 \mathrm{~cm}$. Orientation: WSW-ESE. Fill: Dark brown humus mixed with clay.

\section{Burial rite:}

Inhumation

\section{Description:}

The human remains including a skull, ribs and limb bones were located in the centre of the grave pit in irregular position (Fig. 6.A). 
Position of the grave goods:

Near the limb bones close to the southern side of the pit there was a small ring made of lead.

Grave goods:

1. Ring made of lead. Flat ring slightly pressed. D: 1.3 cm. (Inv. no. M6-2009.A2.216.1) (Fig. 6.A.1).

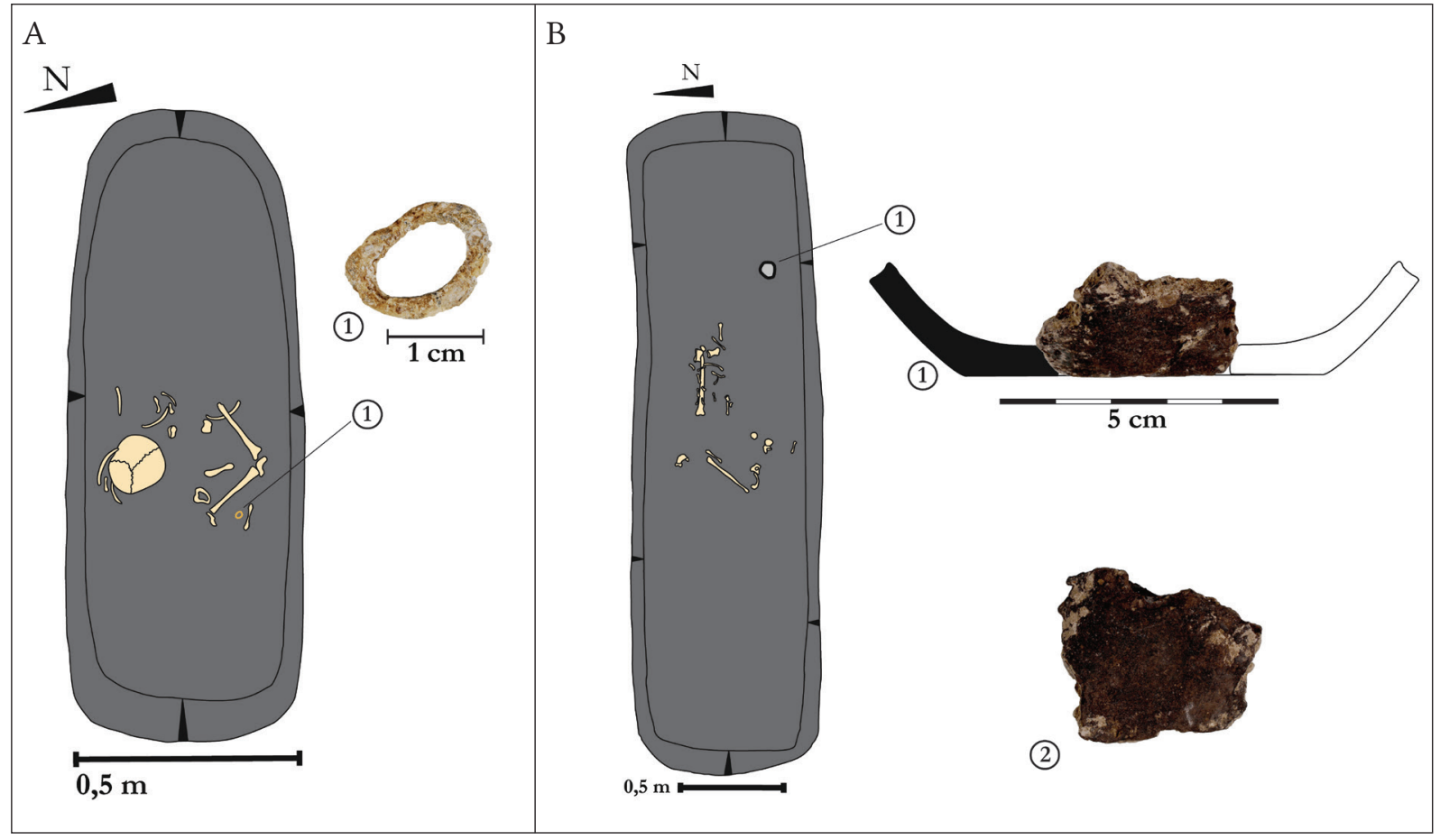

Fig. 6. A - Grave no. 3; B - Grave no. 4.

\section{Grave no. 4 (Feature no. 225)}

Grave pit:

The grave was heavily disturbed. Shape: Shallow, rectangular pit with rounded corners. Dimensions: 322 by $94 \mathrm{~cm}$, relative depth: $25 \mathrm{~cm}$. Orientation: W-E $\left(267^{\circ}\right)$. Fill: Dark brown humus mixed with clay.

\section{Burial rite:}

Inhumation

\section{Description:}

The human remains including ribs and limb bones were located in the centre of the grave pit in irregular position (Fig. 6.B).

Position of the grave goods:

Along the southern side of the pit there were two small sherds.

Grave goods:

1. Pottery sherd of a hand-made vessel. (Inv. no. M6-2010.A2.225.2). Material: Ceramic tempered with sand and gravel. Both the outer and inner surface is dark grey. Shape: Conical lower part and flat bottom of a vessel. Dimensions: L: $3.4 \mathrm{~cm}$; DB: 6.5 cm. (Fig. 6.B.1).

2. Pottery sherd of a hand-made vessel. (Inv. no. M6-2010.A2.225.1). Material: Ceramic tempered with sand and gravel. Both the outer and inner surface is dark brown and black. Shape: Slightly curving body fragment of a vessel. Dimensions: L: $3.8 \mathrm{~cm}$. (Fig. 6.B.2).

\section{Grave no. 5 (Feature no. 230)}

\section{Grave pit:}

The grave was heavily disturbed. Shape: Shallow, rectangular pit with rounded corners, the eastern end of the grave is cut by a pit, thus the exact dimension of the grave is indeterminable. Dimensions: 208(?) by $85 \mathrm{~cm}$, relative depth: $10 \mathrm{~cm}$. Orientation: ENE-WSW/WSW-ENE. Fill: Dark brown humus mixed with clay. 


\section{Burial rite:}

Inhumation

Description:

Presumably due to ancient grave manipulation, there were only a few bones in the grave pit (Fig. 7.A).

Position of the grave goods:

There were a few fragments of different iron objects scattered in different parts of the grave pit.

Grave goods:

1. Iron fragment. Fragment of an iron object of indeterminable function with textile remains. L: $3.2 \mathrm{~cm}$. (Inv. no. M6-2009.A2.230.1) (Fig. 7.A.1); Iron fragment. Fragment of an iron object of indeterminable function. L: $2.8 \mathrm{~cm}$. (Inv. no. M6-2009.A2.230.2) (Fig. 7.A.1); Iron fragment. Fragments of an iron object of indeterminable function. L: $2.5 \mathrm{~cm}$. (Inv. no. M6-2009.A2.230.3) (Fig. 7.A.1).

2. Iron fragment. Fragment of an iron object of indeterminable function, it cannot be ruled out that it was an iron knife. L: 5.8 cm; W: 1.1 cm. (Inv. no. M6-2009.A2.230.4) (Fig. 7.A.2).

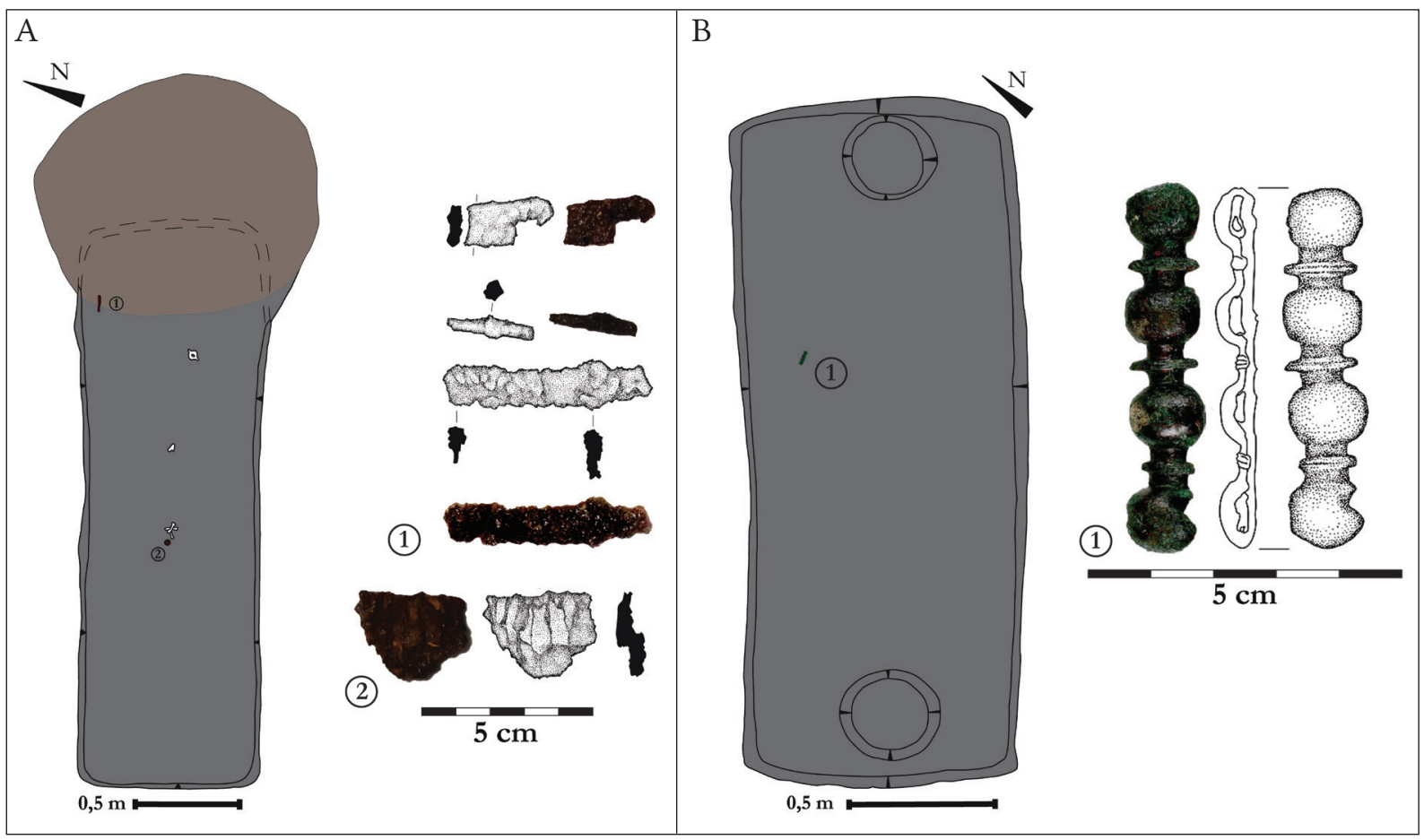

Fig. 7. A - Grave no. 5; B - Grave no. 7.

\section{Grave no. 6 (Feature no. 231)}

\section{Grave pit:}

Shape: Shallow, pit of irregularly rectangular shape with rounded corners. There were two postholes along the longitudinal axes near each end of the grave pit. Dimensions: 351 by $152 \mathrm{~cm}$, relative depth: $33 \mathrm{~cm}$. Orientation: NW-SE $\left(245^{\circ}\right)$. Fill: Dark brown humus mixed with clay.

\section{Burial rite:}

Inhumation

\section{Description:}

Presumably due to ancient grave manipulation or robbery only the leg bones remained intact. Based on their position, however, it might be assumed that the deceased was placed into the grave in supine position. There is a green discolouration on the proximal end of the left femur (Fig. 4).

Position of the grave goods:

In spite of the disturbance of the grave the glass paste beads seem to have remained in their original position, i.e. near the head of the deceased. The segments of an astragal belt were scattered near the left femur. There was a small kantharos near the feet of the deceased. 
Grave goods:

1. Kantharos. (Inv. no. M6-2009.A2.231.1). Material: Ceramic tempered with sand and grained ceramic. Both the outer and inner surfaces are grey with slight brown spots. Shape: Hand-made vessel with outcurving rim, conical neck, profiled bulge, conical lower part and concave bottom. There are the stumps of two symmetrically placed strap handles attached to the shoulder of the vessel. Decoration: Between the handles there are two symmetrically placed bands of densely placed incised lines decorating the shoulder of the vessel. Dimensions: H: $8.0 \mathrm{~cm}$; DR: $6.0 \mathrm{~cm}$; DB: $3.0 \mathrm{~cm}$. (Fig. 9.1).

2. Belt segments. Segments of an astragal belt made of bronze. They are segments comprising four calottes separated by rectangular bars decorated with incised horizontal lines. There is a loop under each calotte. There are 3 pieces, one among them is broken. L: $5.8 \mathrm{~cm}, \mathrm{~W}: 1.2 \mathrm{~cm}$. (Inv. no. M62009.A2.231.2-4) (Fig. 9.2).

3. Glass paste beads. Two large yellow cylindrical beads decorated with longitudinal ribs. L: $1.4-1.5 \mathrm{~cm}$; D: $0.7 \mathrm{~cm}$. (Inv. no. M6-2009.A2.231.7). Glass paste beads. Yellow globular beads of different sizes (6 pieces). D: $0.5-0.8 \mathrm{~cm}$. Turquoise globular beads of different sizes (4 pieces). D: $0.5-0.7 \mathrm{~cm}$. Blue globular bead. D: 0.9 cm. (Inv. no. M6-2009.A2.231.7) (Fig. 9.3).

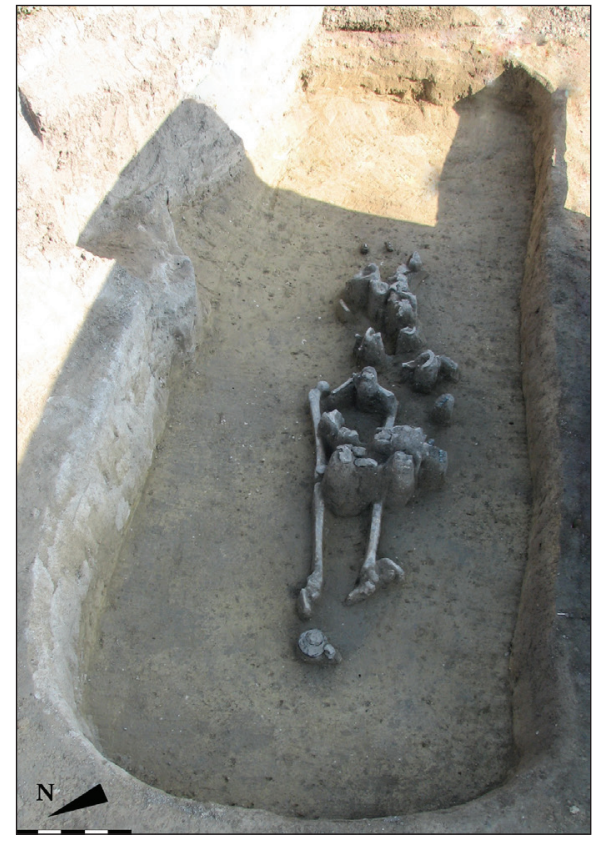

Fig. 8. Photo of Grave no. 6.

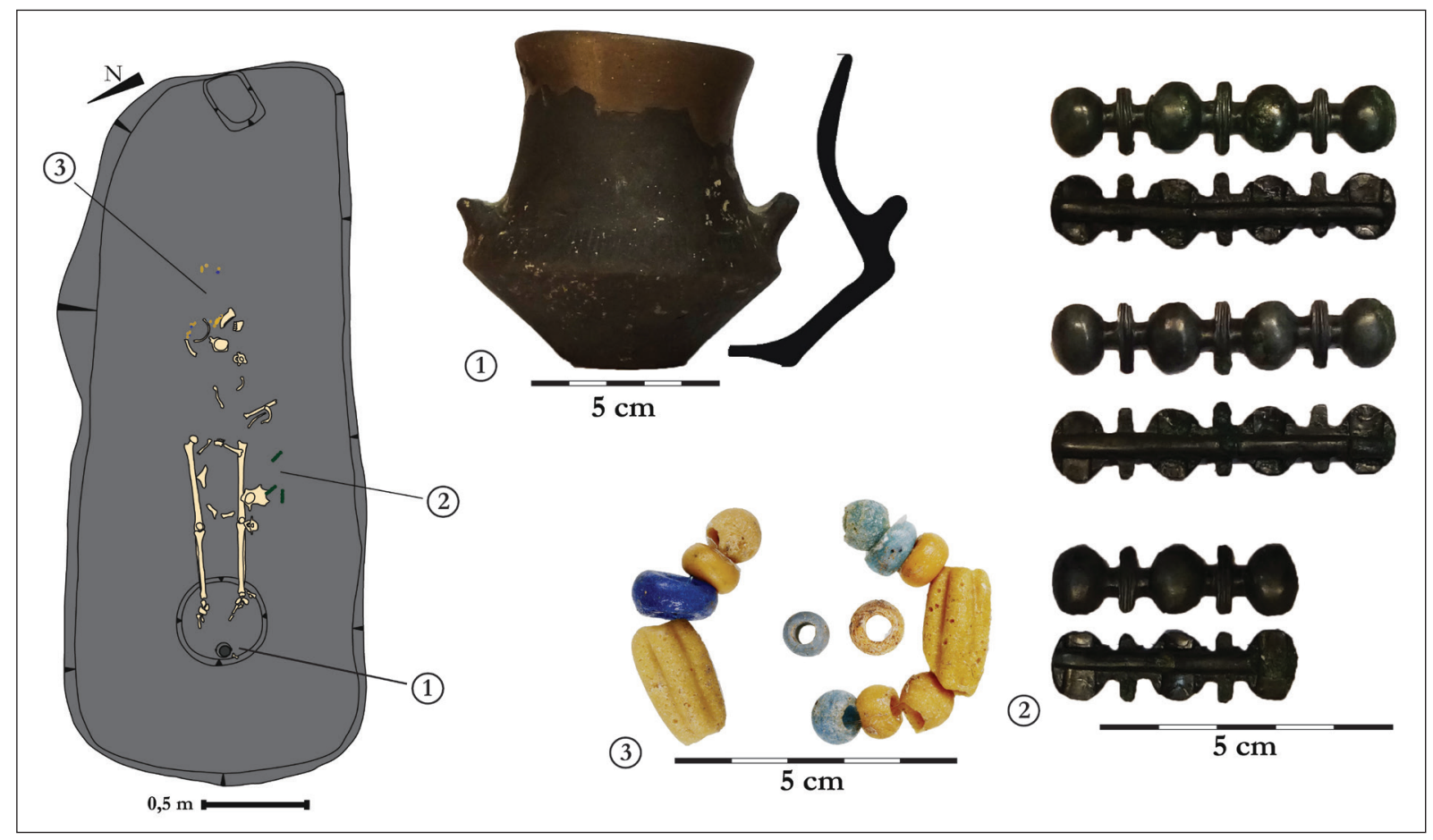

Fig. 9. Grave no. 6.

\section{Grave no. 7 (Feature no. 242)}

\section{Grave pit:}

Large parts of the grave were destroyed during the removal of the humus layer. Shape: Shallow, rectangular pit with rounded corners. There were two postholes along the longitudinal axes near each end of the grave pit. Dimensions: 236 by $96 \mathrm{~cm}$, relative depth: $10 \mathrm{~cm}$. Orientation: SW-NE/NE-SW. Fill: Dark brown humus mixed with clay. 


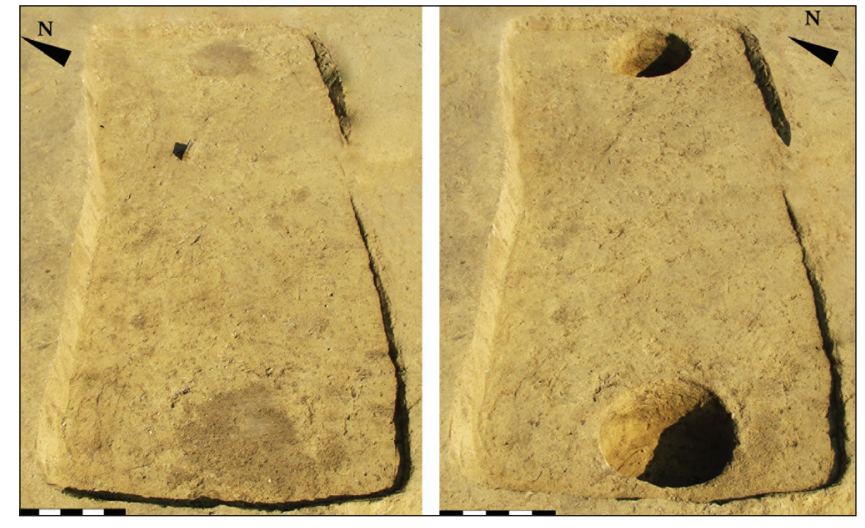

Fig. 10. Photos of Grave no. 7.

\section{Burial rite:}

Indeterminable

\section{Description:}

Presumably due to the disturbance caused by the removal of the humus layer no human remains came to light from the grave, however, it cannot be ruled out that their absence is the result of ancient grave manipulation or robbery. Also, the possibility of the grave being a cenotaph cannot be excluded either (Fig. 10).

Position of the grave goods:

There was only a single grave good, a segment of an astragal belt found in the northern part of the grave pit.

Grave goods:

1. Belt segment. Segments of an astragal belt made of bronze, comprising four calottes separated by rectangular bars decorated with incised horizontal lines. There is a loop under each calotte. There are 3 pieces, one of which is broken. L: $5.8 \mathrm{~cm}, \mathrm{~W}: 1.2 \mathrm{~cm}$. (Inv. no. M6-2009.A2.242.1) (Fig. 7.B.1).

\section{Grave no. 8 (Feature no. 263)}

Grave pit:

Shape: Shallow pit of irregular rectangular shape with rounded corners. There were two postholes along the longitudinal axes near each end of the grave pit. Dimensions: 280 by $105 \mathrm{~cm}$, relative depth: $10 \mathrm{~cm}$. Orientation: WNW-ESE $\left(250^{\circ}\right)$. Fill: Dark brown humus mixed with clay.

\section{Burial rite:}

Inhumation

\section{Description:}

Skeleton lying in supine position, the severely damaged skull is directed southwest. The bones are in relatively good condition. The skull leans slightly to left. Presumably due to ancient grave manipulation or robbery the chest area is heavily disturbed, as a result, most ribs the cervical and thoracic vertebrae and the bones of the right forearm and hand are missing. The left forearm is placed onto the chest (Fig. 11).

Position of the grave goods:

Despite the disturbance affecting the chest area, a great number of grave goods came to light. There were several glass paste beads scattered
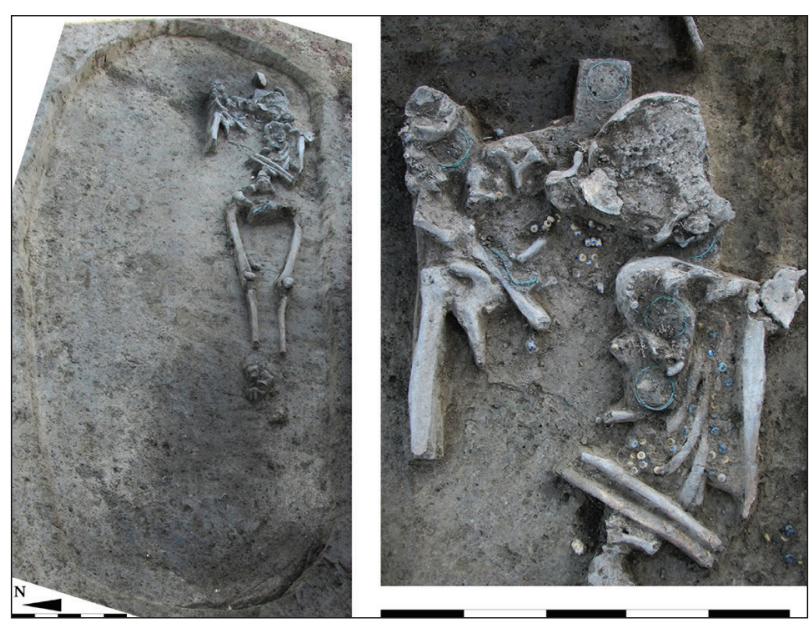

Fig. 11. Photos of Grave no. 8. around the head and the chest area. There were six spirals made of bronze wire, two of them near the right side of the head, two were situated between the remains of the skull and the left shoulder, further two came to light from the left side of the chest area. One of the bronze fibulae could have been observed in situ on the right shoulder. In contrast, two of them were in the pelvis area. There was an amber bead on the right side of the lumbar vertebrae. Between the two knees a ceramic spindle whorl was found.

Grave goods:

1. Bronze fibula. Fragments of a Certosa fibula of Type $\mathrm{V}$ made of bronze. The fragment of the bow has a transversal rib near the foot. The spring of the fibula and parts of its pin are missing. The triangular foot decorated with six incised point-circle motifs ends in a flat knob, its trapezoidal catch-plate is holding the pin's end. L: 6.4 cm; FL: $2.1 \mathrm{~cm}$. (Inv. no. M6-2009.A2.263.17) (Fig. 12.1).

2. Bronze fibula. Certosa fibula of Type $\mathrm{V}$ made of bronze. The bow with a slight longitudinally running edge has two transversal ribs on either ends. The fibula has a three-coil spring on its left side. The triangular 
foot decorated with six incised point-circle motifs ends in a flat knob, its trapezoidal catch-plate is no longer holding the pin. L: $5.8 \mathrm{~cm}$; FL: $2.0 \mathrm{~cm}$. (Inv. no. M6-2009.A2.263.18) (Fig. 12.2).

3. Bronze fibula. Certosa fibula of Type $\mathrm{V}$ made of bronze. The bow with a slight longitudinally running edge has two transversal ribs on either ends. The fibula has a three-coil spring on its left side. The triangular foot ends in a flat knob, its trapezoidal catch-plate is not holding the pin. L: $5.8 \mathrm{~cm}$; FL: $2.0 \mathrm{~cm}$. (Inv. no. M6-2009.A2.263.6) (Fig. 12.3).

4. Temporal ring. Fragments of a temporal ring made of thin spirally curved bronze wire with hardly visible twisted decoration (4 pieces). D: 4.4 cm. (Inv. no. M6-2009.A2.263.9) (Fig. 12.4).

5. Temporal ring. Fragments of a temporal ring made of thin spirally curved bronze wire with hardly visible twisted decoration (3 pieces). D: $4.5 \mathrm{~cm}$. (Inv. no. M6-2009.A2.263.21) (Fig. 12.5).

6. Temporal ring. Fragments of a temporal ring made of thin spirally curved bronze wire with hardly visible twisted decoration. The end of the wire is slightly curved. (5 pieces). D: $4.2 \mathrm{~cm}$. (Inv. no. M6-2009.A2.263.10) (Fig. 12.6).

7. Temporal ring. Fragments of a temporal ring made of thin spirally curved bronze wire with hardly visible twisted decoration. The end of the wire is thinner and slightly curved (2 pieces). D: $4.4 \mathrm{~cm}$. (Inv. no. M62009.A2.263.1) (Fig. 12.7).

8. Temporal ring. Fragment of a temporal ring made of thin spirally curved bronze wire with hardly visible twisted decoration. D: 4.3 cm. (Inv. no. M6-2009.A2.263.2) (Fig. 12.8).

9. Temporal ring. Fragments of a temporal ring made of thin spirally curved bronze wire with hardly visible twisted decoration. (4 pieces). D: 4.3 cm. (Inv. no. M6-2009.A2.263.3) (Fig. 12.9).

10. Fragments of the temporal rings. Further fragments of the above temporal rings made of thin spirally curved bronze wire with hardly visible twisted decoration (25 pieces). They are not depicted. (Inv. no. M6-2009.A2.263.4; M6-2009.A2.263.7; M6-2009.A2.263.8; M6-2009.A2.263.11; M6-2009.A2.263.12) (Fig. 12.10).

11. Spindle whorl. Large, made of burnt clay. D: $3.1 \mathrm{~cm} ; \mathrm{H}: 2.0 \mathrm{~cm}$. (Inv. no. M6-2009.A2.263.20) (Fig. 12.11).

12. Amber bead. Severely corroded amber bead decorated with oblique ribs. D: 1.7 cm. (Inv. no. M6-2009. A2.263.15) (Fig. 13.12).

13. Glass paste beads. Yellow globular beads (11 pieces). D: $0.8-1.1 \mathrm{~cm}$. Yellow beads with four blue-white eye motifs arranged in one row (12 pieces). D: $0.9 \mathrm{~cm}$. Turquoise beads with four blue-white eye motifs arranged in one row. D: $1.0 \mathrm{~cm}$. (Inv. no. M6-2009.A2.263.5) (Fig. 13.13).

14. Various glass paste beads. Yellow globular beads (21 pieces). D: 0.8-1.1 cm. Blue globular beads (20 pieces). D: $1.0 \mathrm{~cm}$. Yellow beads with four blue-white eye motifs arranged in one row (9 pieces). D: $0.9 \mathrm{~cm}$. Turquoise beads with four blue-white eye motifs arranged in one row (2 pieces). D: $0.8-1.0 \mathrm{~cm}$. Yellow beads with eight blue-white eye motifs arranged in two rows (4 pieces). D: $0.8-1.2 \mathrm{~cm}$. Turquoise beads with

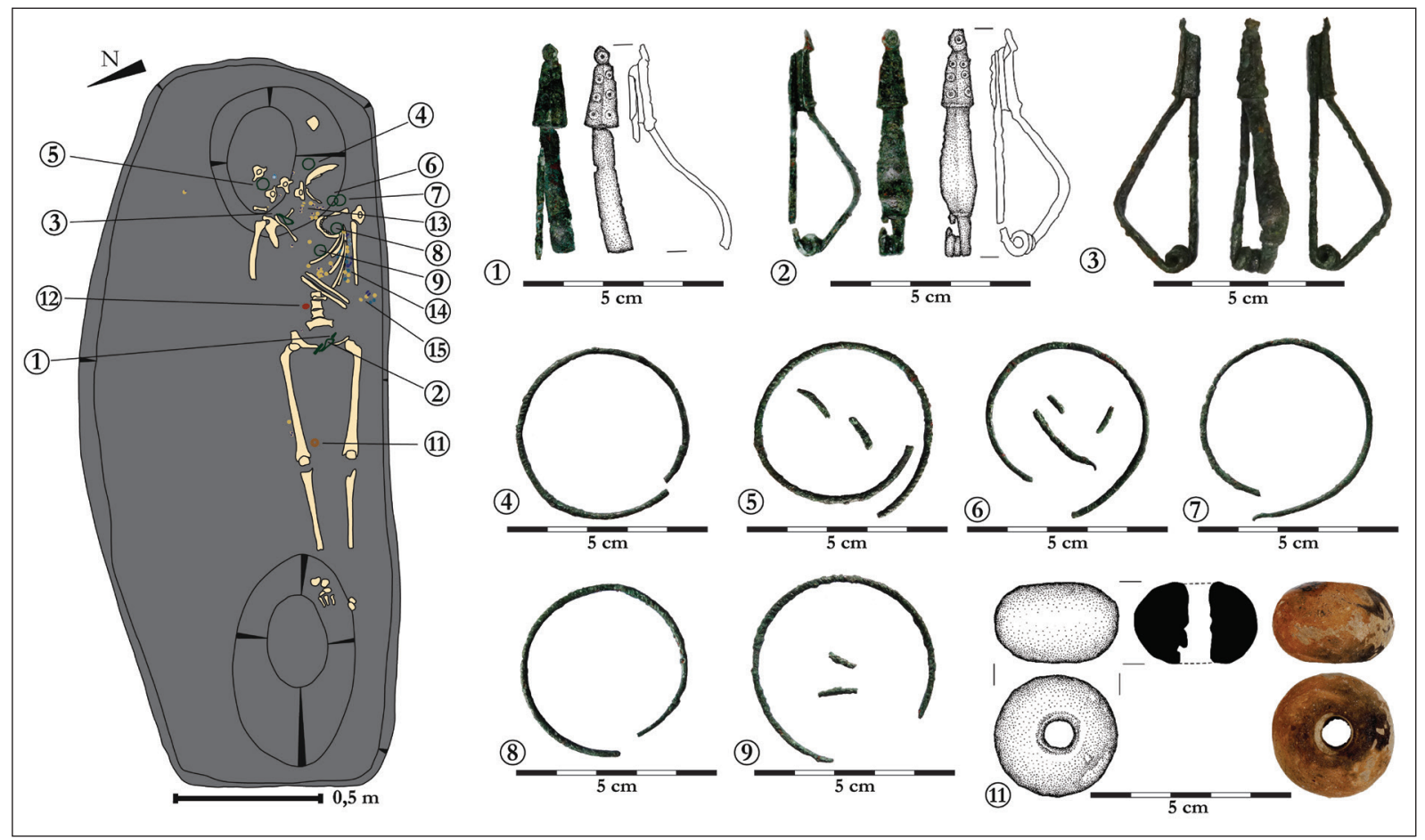

Fig. 12. Grave no. 8 
eight blue-white eye motifs arranged in two rows (2 pieces). D: 0.8-1.4 cm. (Inv. no. M6-2009.A2.263.13). Twin beads made of glass paste. Two yellow twin beads with four blue-white eye motifs on each segment. L: 0.9-1.2 cm; D: 0.7-0.9 cm. (Inv. no. M6-2009.A2.263.16; M6-2009.A2.263.19) (Fig. 13.14).

15. Various glass paste beads. Blue globular beads (7 pieces). D: $1.0 \mathrm{~cm}$. Yellow globular beads (8 pieces). D: $0.8-1.1 \mathrm{~cm}$. Yellow beads with four blue-white eye motifs arranged in one row (12 pieces). D: $0.9 \mathrm{~cm}$. (Inv. no. M6-2009.A2.263.14) (Fig. 13.15).

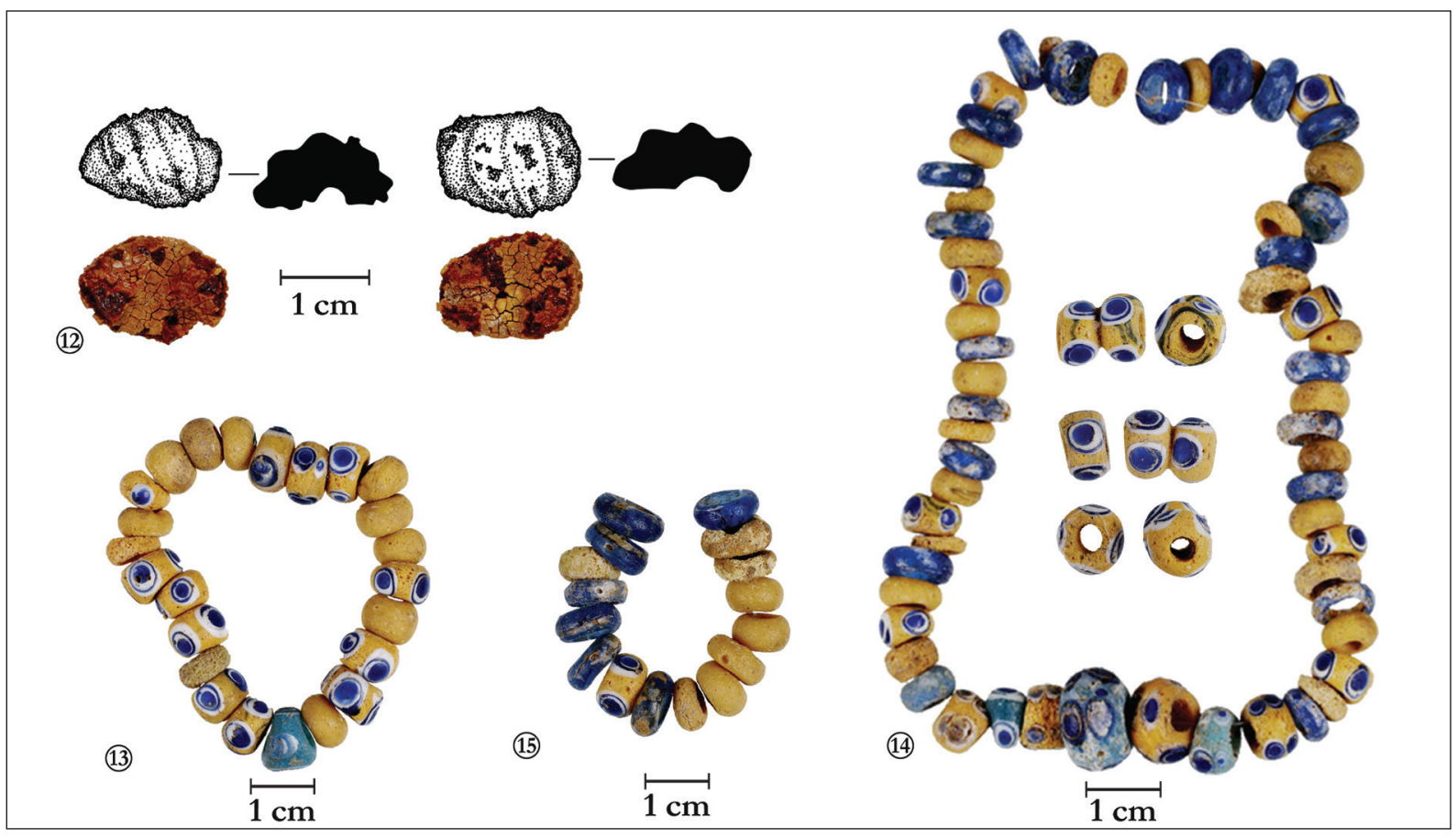

Fig. 13. Grave no. 8

\section{Grave no. 9 (Feature no. 268)}

Grave pit:

Shape: Rectangular pit with rounded corners. Dimensions: 236 by $67 \mathrm{~cm}$, relative depth: $50 \mathrm{~cm}$. Orientation: S-N $\left(11^{\circ}\right)$. Fill: Dark brown humus mixed with clay.

Burial rite:

Inhumation

\section{Description:}

Skeleton of an infant in supine position. The bones were modestly preserved (Fig. 14.A).

Position of the grave goods:

There were two glass paste beads in the chest area. West of the body an approximately $6 \mathrm{~cm}$ wide and some $28 \mathrm{~cm}$ long carbonized piece of wood was found southeast of which a hand-made bowl came to light.

Grave goods:

1. Hand-made bowl. (Inv. no. M6-2009.A2.268.1). Material: Ceramic tempered with sand and gravel. Both the outer and inner surfaces are light brown with a few darker spots. Shape: Hand-made vessel with inverted rim, curving conical lower part and profiled flat bottom. Dimensions: H: $6.0 \mathrm{~cm}$; DR: $13.0 \mathrm{~cm}$; DB: $8.0 \mathrm{~cm}$. (Fig. 14.A.2).

2. Glass paste beads. Yellow beads (3 pieces) and fragments of yellow beads (3 pieces). D: $0.6 \mathrm{~cm}$. (Inv. no. M6-2009.A2.268.3) (Fig. 14.A.1).

\section{Grave no. 10 (Feature no. 281)}

\section{Grave pit:}

Shape: The grave was dug into a Neolithic pit, thus its contours were hardly visible. Dimensions: 100(?) by $50\left(\right.$ ?) $\mathrm{cm}$, relative depth: $10 \mathrm{~cm}$. Orientation: ENE-WSW $\left(108^{\circ}\right)$. Fill: In the northern part of the grave it was dark grey, in the southern half it was lighter. 


\section{Burial rite:}

Inhumation

\section{Description:}

Skeleton of an infant in supine position. The bones were badly preserved, many of them completely missing. The southern half of the grave pit was entirely empty (Fig. 14.B).

\section{Position of the grave goods:}

There were three yellow beads under the jaw. Wooden remains came to light on the right side of the skeleton, further to the west a bowl was found.

\section{Grave goods:}

1. Glass paste beads. One large heavily corroded bead. D: $1.4 \mathrm{~cm}, \mathrm{H}: 0.8 \mathrm{~cm}$. One smaller yellow bead. D: 0.9 cm. (Inv. no. M6-2009.A2.281.1) (Fig. 14.B.1).

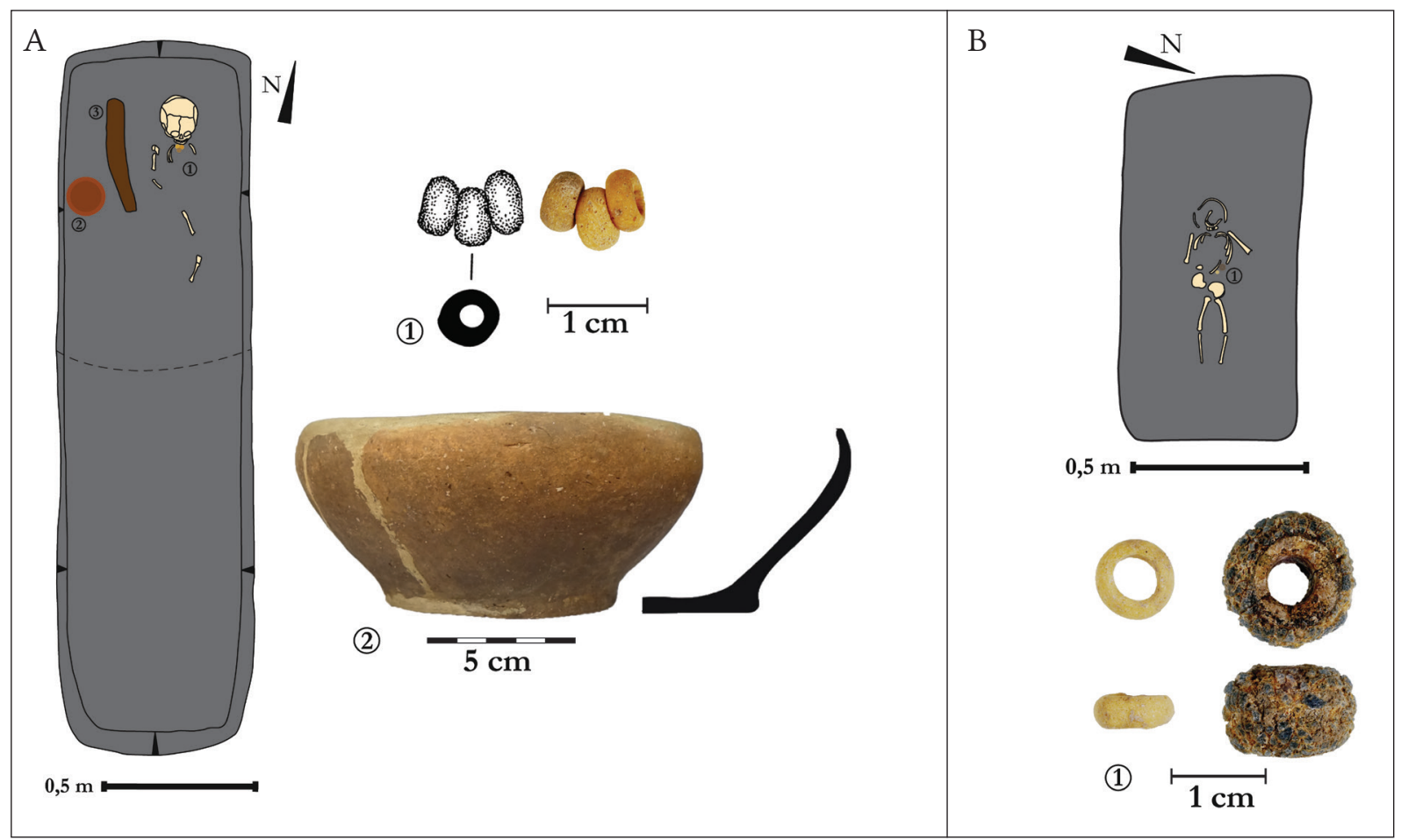

Fig. 14. A - Grave no. 9; B - Grave no. 10.

\section{Grave no. 11 (Feature no. 292)}

\section{Grave pit:}

Shape: Rectangular pit with rounded corners. The eastern part of the grave was disturbed by a later dug pit. Dimensions: 255 by $90 \mathrm{~cm}$, relative depth: $20 \mathrm{~cm}$. Orientation: W-E. Fill: The fill of the western and eastern halves of the grave were clearly different.

\section{Burial rite:}

Inhumation

\section{Description:}

Skeleton in supine position. Presumably due to ancient disturbance (a pit cutting the eastern half of the grave) the bones of the upper part of the body were completely missing, only the bones of the legs remained intact (Fig. 15).

Position of the grave goods:

In spite of the disturbance there were two fibulae and one glass bead east of the right femur.

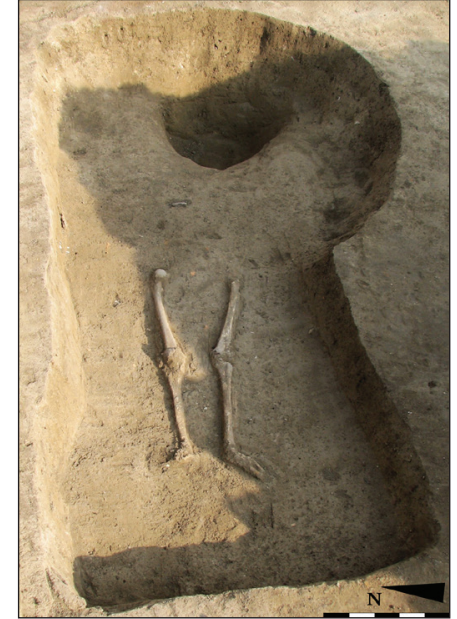

Fig. 15. Photo of Grave no. 11 and the later dug pit. 
Grave goods:

1. Glass bead. Large prism shaped bead of turquoise colour. L: $4.1 \mathrm{~cm}$; W: $1.2 \mathrm{~cm}$. (Inv. no. M6-2009.A2.292.5) (Fig. 16.A.1).

2. Bronze fibula. Certosa fibula of Type $\mathrm{V}$ made of bronze. The bow with a slight longitudinally running edge has two transversal ribs on either ends. The fibula has a three-coil spring on its left side. The triangular foot decorated with four incised point-circle motifs ends in a flat knob, its trapezoidal catch-plate is still holding the pin. L: $6.0 \mathrm{~cm}$; FL: $2.1 \mathrm{~cm}$. (Inv. no. M6-2009.A2.292.3) (Fig. 16.A.2).

3. Bronze fibula. Certosa fibula of Type $\mathrm{V}$ made of bronze. The bow with a slight longitudinally running edge has two transversal ribs on either ends. The fibula has a three-coil spring on its left side. The triangular foot decorated with six incised point-circle motifs arranged in two rows ends in a flat knob, its trapezoidal catch-plate is still holding the pin. L: $5.0 \mathrm{~cm}$; FL: $2.0 \mathrm{~cm}$. (Inv. no. M6-2009.A2.292.3) (Fig. 16.A.3).

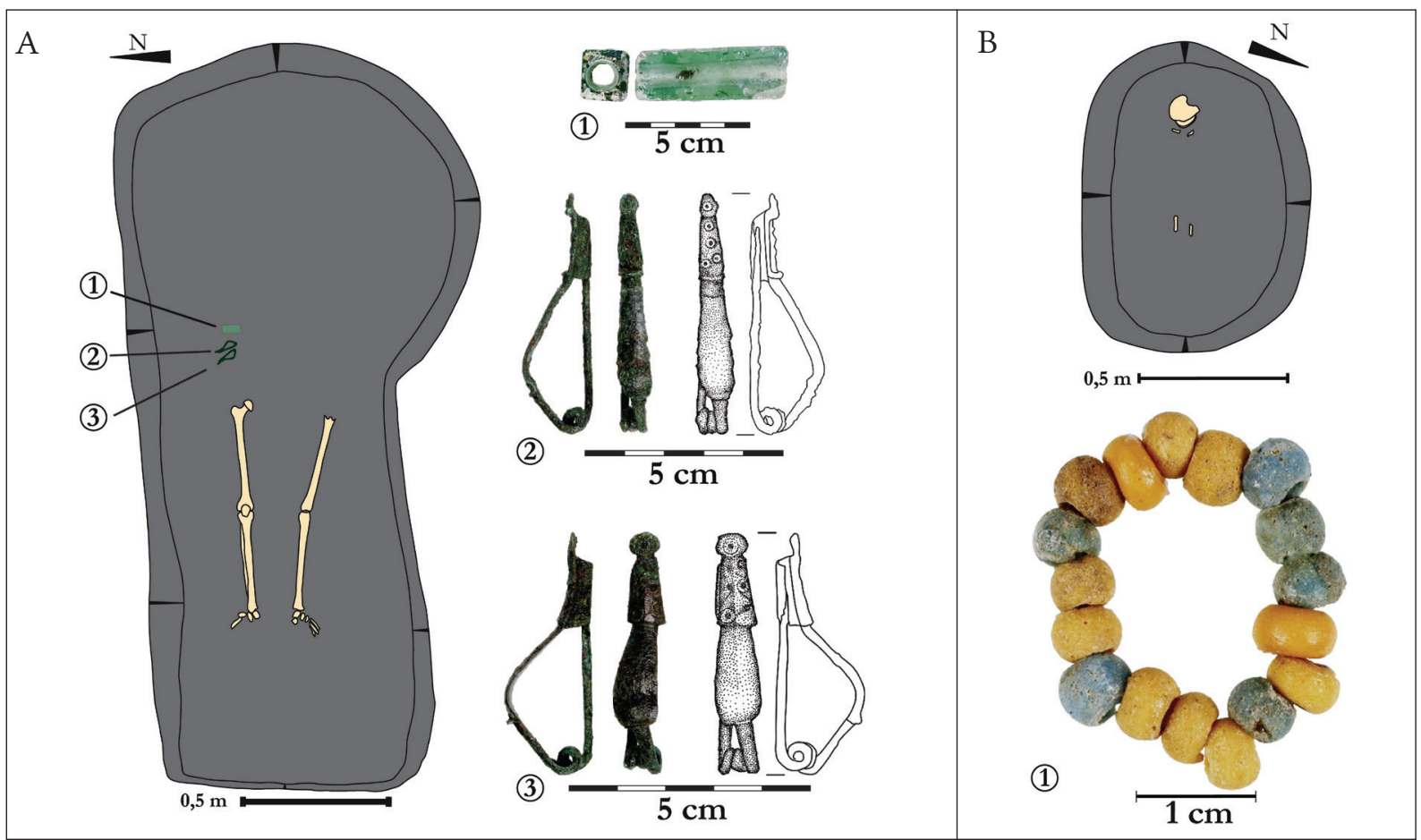

Fig. 16. A - Grave no. 11; B - Grave no. 12.

\section{Grave no. 12 (Feature no. 333)}

\section{Grave pit:}

The grave was slightly disturbed during the removal of the humus layer. Shape: Shallow oval pit with bevelled walls. Dimensions: 105 by $80 \mathrm{~cm}$, relative depth: $5-7 \mathrm{~cm}$. Orientation: ENE-WSW $\left(109^{\circ}\right)$. Fill: Dark brown humus mixed with clay.

\section{Burial rite:}

Inhumation

\section{Description:}

Skeleton of an infant in supine position. Only bones of the skull and the leg and some teeth remained (Fig. 16.B).

Position of the grave goods:

The glass paste beads were under and around the jaw.

Grave goods:

1. Various glass paste beads. Yellow globular beads (11 pieces). D: $0.6-0.7 \mathrm{~cm}$. Turquoise globular beads (6 pieces). D: $0.6 \mathrm{~cm}$. (Inv. no. M6-2009.A2.333.1) (Fig. 16.B.1).

\section{Grave no. 13 (Feature no. 421)}

\section{Grave pit:}

Shape: Shallow rectangular pit with rounded corners. There were two postholes along the longitudinal axes near each end of the grave pit. Dimensions: 222 by $109 \mathrm{~cm}$, relative depth: $11 \mathrm{~cm}$. Orientation: SE-NW $\left(49^{\circ}\right)$. 
Fill: Dark brown humus mixed with clay.

\section{Burial rite:}

Inhumation

\section{Description:}

Skeleton in supine position. The grave might have been slightly disturbed, especially in the area around the head. As a result, the bones of the skull are nearly entirely missing. Bones of the right forearm and the left arm are also missing. There were cremated bones in the northeaster corner of the grave possibly originating from Grave no. 14 that was situated next to this burial (Fig. 17).

Position of the grave goods:

There was a small iron disk on the right hip bone. The iron knife was found under the left hip bone.

Grave goods:

1. Iron disc. Small perforated iron disc. D: $2.6 \mathrm{~cm}$. (Inv. no. M62009.A2.421.1) (Fig. 18.A.1).

2. Iron knife. Fragments of a short heavily corroded curved knife with tang (2 pieces). L: $6.4 \mathrm{~cm}$. (Inv. no. M6-2009.A2.421.2) (Fig. 18.A.2).

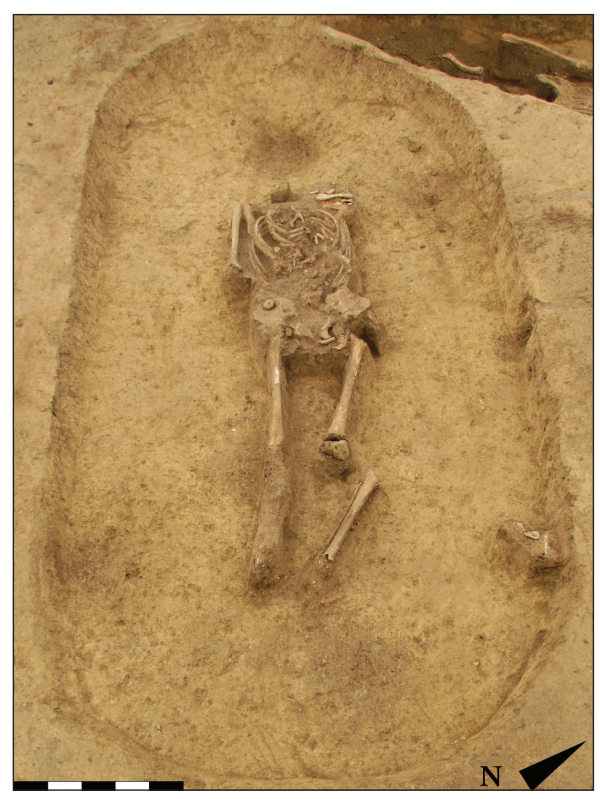

Fig. 17. Photos of Grave no. 13.

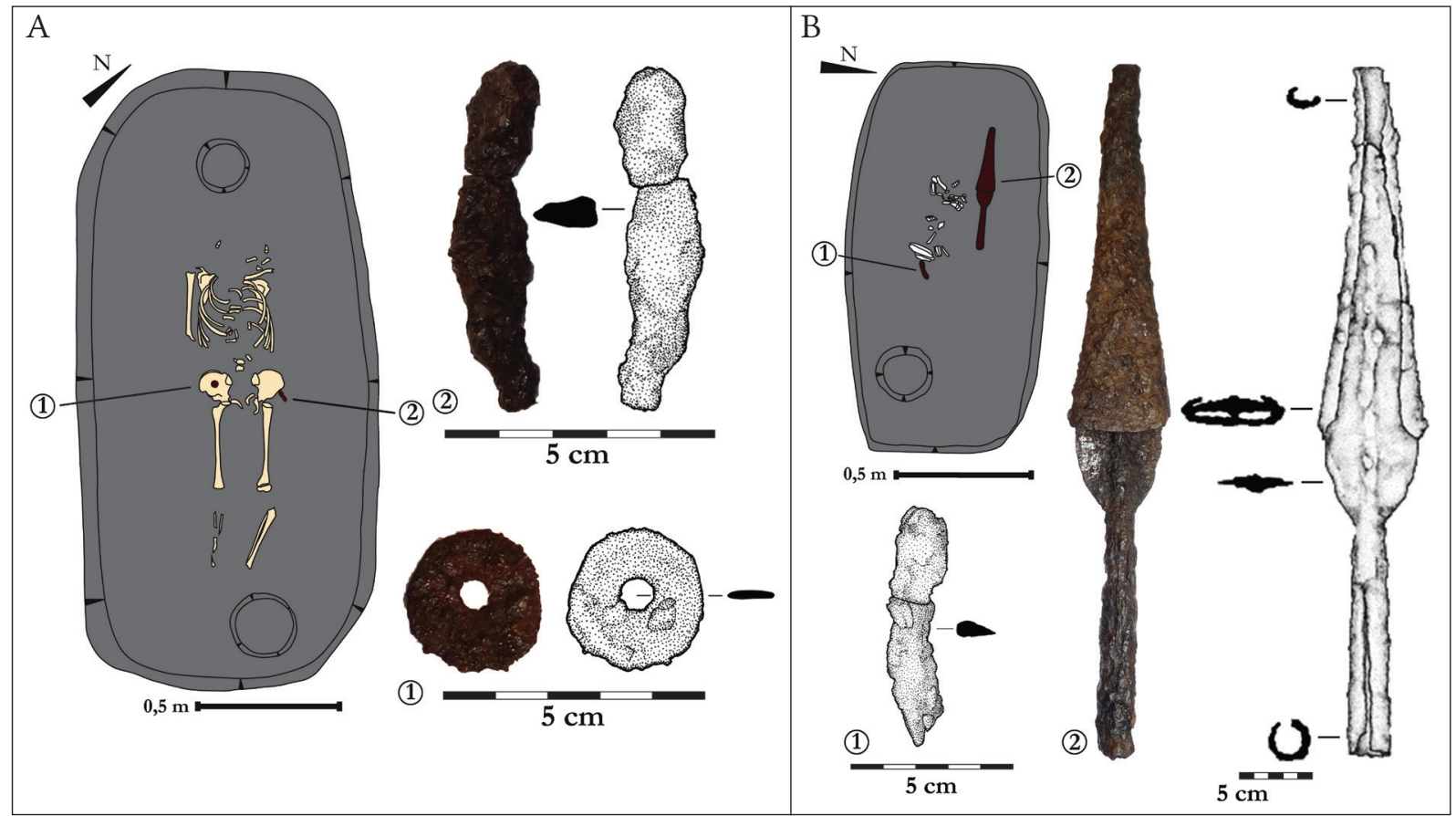

Fig. 18. A - Grave no. 13; B - Grave no. 14.

\section{Grave no. 14 (Feature no. 423)}

\section{Grave pit:}

Shape: Shallow rectangular pit with rounded corners. There was a single posthole in the eastern corner of the grave pit. Dimensions: 148 by $109 \mathrm{~cm}$, relative depth: $8 \mathrm{~cm}$. Orientation: W-E $\left(96^{\circ}\right)$. Fill: Dark brown humus mixed with clay.

\section{Burial rite:}

Cremation

\section{Description:}

The grave contained cremated human remains that formed a heap near to the centre of the grave pit (Fig. 19). 
Position of the grave goods:

There was a spearhead pointed towards west, placed north of the cremated bones. West of the bones a small iron knife was found.

Grave goods:

1. Iron knife. Fragments of a short heavily corroded curved knife with tang (2 pieces). L: $7.4 \mathrm{~cm}$. (Inv. no. M6-2009.A2.423.1) (Fig. 18.B.1).

2. Iron spearhead. Iron spearhead with socket and blade of nearly equal length. The cross-section of the blade is rhombic. The midrib of the blade runs to the point of the blade. The blade is covered by a sheath, an iron sheet bent over the edges of the blade. L: $45.4 \mathrm{~cm}$; length of the blade: $24.0 \mathrm{~cm}$; Max. W: $5.7 \mathrm{~cm}$; length of the sheath: $24.4 \mathrm{~cm}$. (Inv. no. M6-2009.A2.423.2) (Fig. 18.A.2).

\section{Grave no. 15 (Feature no. 465)}

\section{Grave pit:}

Shape: Shallow rectangular pit with rounded corners. There were two postholes along the longitudinal axis near each end of the grave pit. Dimensions: 268 by $126 \mathrm{~cm}$, relative depth: $21 \mathrm{~cm}$. Orientation: $\mathrm{SW}-\mathrm{NE}\left(300^{\circ}\right)$. Fill: Dark brown humus mixed with clay.

\section{Burial rite:}

Inhumation

\section{Description:}

Well-preserved skeleton in supine position, slightly lying on its right side. The skull is turned to the right, facing towards NNE. The hands are placed in front of the skull. The bones of the hands are partially missing, so is a part of the ilia. The legs are well-preserved, both legs are in a stretched position, however, they are slightly shifted towards north (Fig. 20).

Position of the grave goods:

There was a spearhead near the hands and the skull parallel to the longitudinal axis of the grave pit. Near the socket of the spearhead there was a bronze fibula. Southwest of the right elbow there was a bronze belt clasp. Three further parts of the decorated belt scattered around the waist. These were accompanied by a whetstone and an iron awl on the left side of the spine. Also, a ceramic vessel was found next to the right tibia.

\section{Grave goods:}

1. Hand-made kantharos. (Inv. no. M6-2009.A2.203.1). Material: Ceramic, finely tempered with sand and grained ceramic. Both the outer and inner surface is dark brown. The outer surface is smoothed. Shape: Outcurving rim, conical neck and conical lower part with flat bottom. The shoulder and the lower part of the vessel are separated by a sharp line. There are two symmetrically placed strap handles raised above the rim and attached to the shoulder of the vessel. Decoration: Between the handles there are two symmetrically placed bands of densely placed fluted lines decorating the shoulder of the vessel. Dimensions: $\mathrm{H}: 12.2$ cm; DR: $7.3 \mathrm{~cm}$; DB: 4.0 cm. (Fig. 21.1).

2. Iron spearhead. Leaf-shaped iron spearhead with pronounced midrib on both sides running from the socket to the point. L: $19.5 \mathrm{~cm}$; length of the blade: $12.5 \mathrm{~cm}$. (Inv. no. M6-2009.A2.465.3) (Fig. 21.2).

3. Bronze fibula. Certosa fibula of Type V made of bronze. The bow

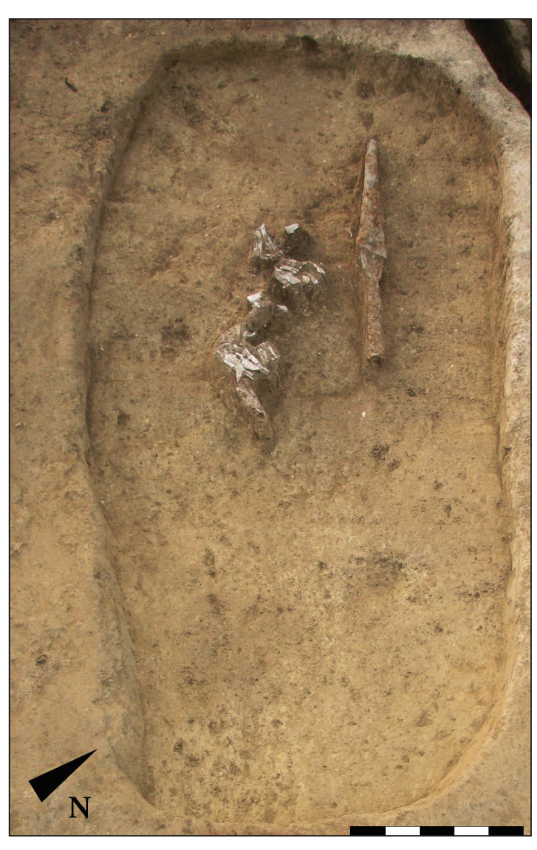

Fig. 19. Photo of Grave no. 14.
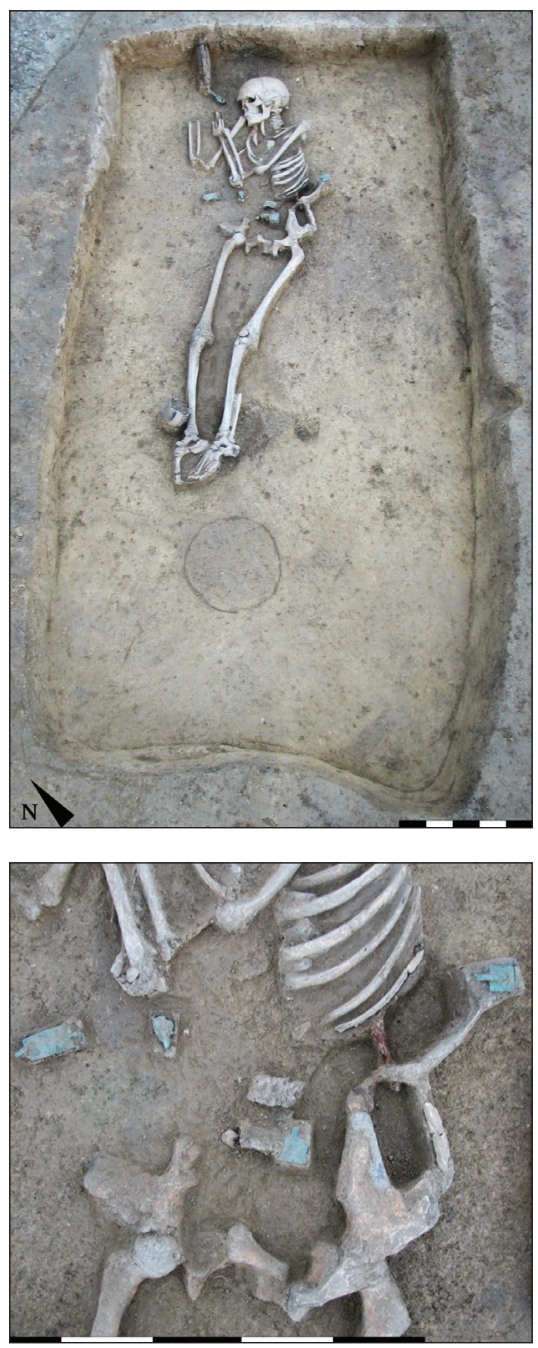

Fig. 20. Photos of Grave no. 15. 
with a slight longitudinally running edge has two transversal ribs on either ends. The fibula has a threecoil spring on its right side. The triangular foot ends in a flat knob, its trapezoidal catch-plate is not holding the broken pin. L: $6.6 \mathrm{~cm}$; FL: $2.2 \mathrm{~cm}$. (Inv. no. M6-2009.A2.465.4) (Fig. 21.3).

4. Belt clasp. Rectangular bronze sheet with a $0.5 \mathrm{~cm}$ wide bronze bar attached to it. This central bar whose end bends backwards. On the other side there is a more massive hook riveted to the central bar. This hook also bends backwards. The central bar is decorated with oblique bands of incised lines. There are small oblique incised lines along the longer edges of the bronze sheet whose decoration also includes several point-circle motifs. L: $6.1 \mathrm{~cm}$; length of the bronze sheet: $4.3 \mathrm{~cm}$; width of the bronze sheet: $2.3 \mathrm{~cm}$. (Inv. no. M6-2009.A2.465.5) (Fig. 21.4).

5. Belt mount. Square shaped belt mount made of bronze sheet with a $0.5 \mathrm{~cm}$ wide band bent over the sheet and riveted onto its back. The front of the sheet is decorated with three point-circle motifs and small oblique incised lines along its lower edge. The band is decorated with an X-shaped incision and two incised lines below it. L: $3.1 \mathrm{~cm}$; W: $3.2 \mathrm{~cm}$; the length of the sheet: $2.1 \mathrm{~cm}$. (Inv. no. M6-2009.A2.465.7) (Fig. 21.5).

6. Belt mount. Square shaped belt mount made of bronze sheet with a $0.5 \mathrm{~cm}$ wide band bent over the sheet and riveted onto its back. The front of the sheet is decorated with three point-circle motifs and small oblique incised lines along its lower edge. The band is decorated with an X-shaped incision two incised lines below it. L: $3.1 \mathrm{~cm}$; W: $3.2 \mathrm{~cm}$; the length of the sheet: $2.1 \mathrm{~cm}$. (Inv. no. M6-2009.A2.465.8) (Fig. 21.6).

7. Belt mount. Belt mount made of bronze sheet with a $0.5 \mathrm{~cm}$ wide band bent over the sheet and riveted onto its back. The front of the sheet is decorated with three incised point-circle motifs with two of them arranged along the edge of the partially damaged sheet and one near the centre. L: $2.9 \mathrm{~cm}$; W: $1.8 \mathrm{~cm}$; the length of the sheet: $2.1 \mathrm{~cm}$. (Inv. no. M6-2009.A2.465.6) (Fig. 21.7).

8. Whetstone. Fragment of a prism-shaped whetstone with rectangular cross-section. L: $9.0 \mathrm{~cm} ; \mathrm{W}: 1-2.1 \mathrm{~cm}$. (Inv. no. M6-2009.A2.465.10) (Fig. 21.8).

9. Iron awl. Thin iron rod with wooden remains, possibly remains of the haft of the tool. L: $5.8 \mathrm{~cm}$. (Inv. no. M6-2009.A2.465.9) (Fig. 21.9).
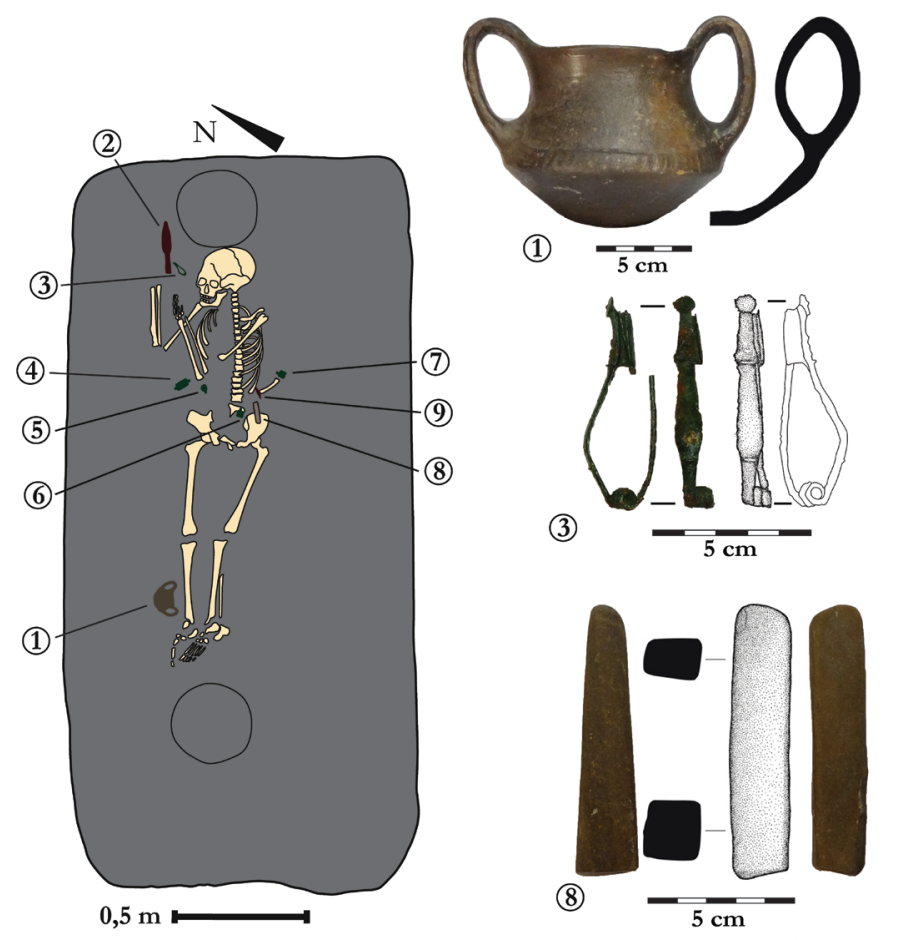

(1)

(4)

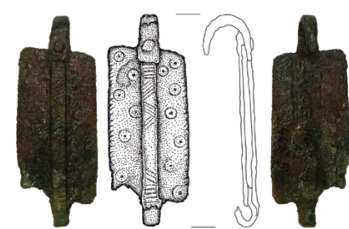

(5)
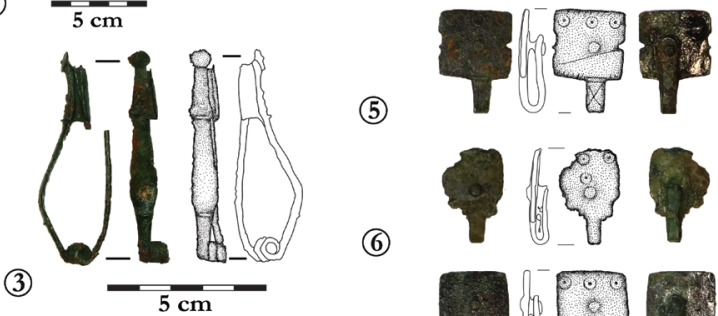

(6)
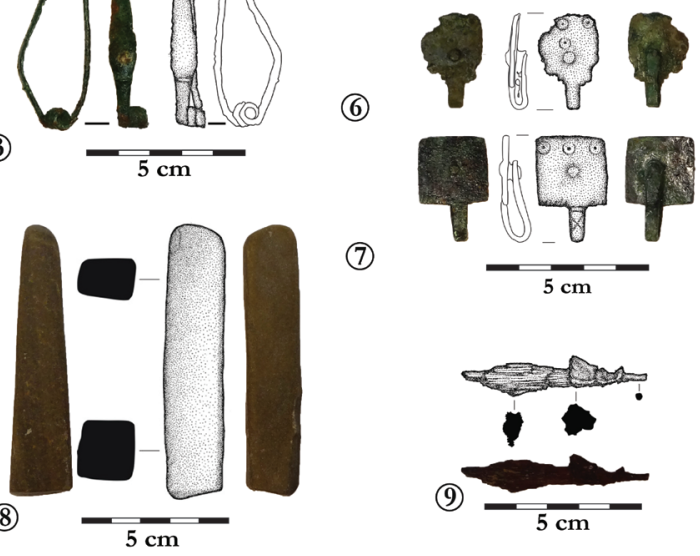

(2)
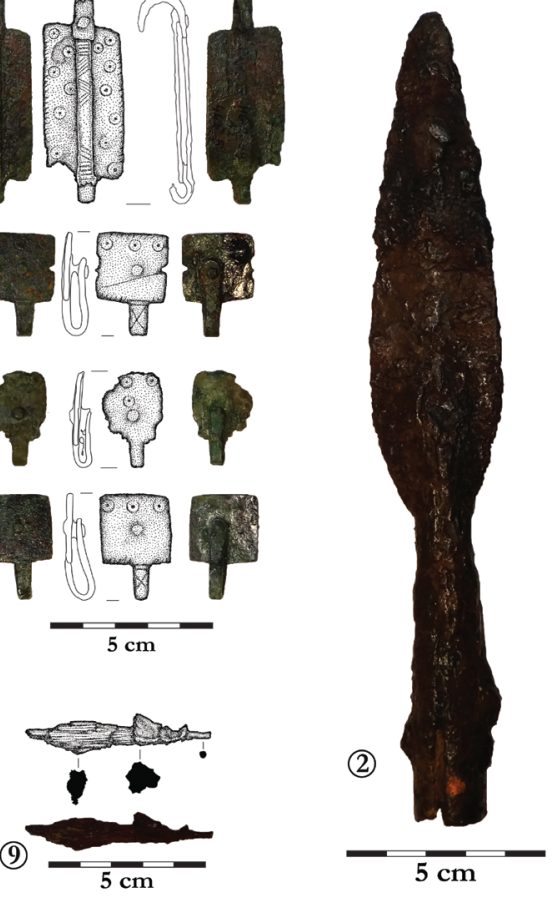

Fig. 21. Grave no. 15.

\section{Grave no. 16 (Feature no. 433)}

\section{Grave pit:}

Shape: The items belonging to the grave came to light during the removal of the humus layer, thus it was impossible to fully document the exact layout of heavily disturbed grave pit. Dimensions: N/A. Orientation: N/A. Fill: Dark brown humus mixed with clay. 
Burial rite:

Cremation in an urn

Description:

The calcined human remains came to light among the shards of the urn.

Position of the grave goods:

An iron knife and a whetstone probably associated with the grave were found in the removed earth, their exact position within the grave could not be documented.

Grave goods:

1. Urn. ${ }^{3}$ (Inv. no. M6-2009.A2.433.3).

2. Iron knife. Short curved knife with tang. L: $5.4 \mathrm{~cm}$; W: $1.6 \mathrm{~cm}$. (Inv. no. M6-2009.A2.433.2).

3. Whetstone. Fragment of a prism-shaped whetstone with rectangular and oval cross-section. L: $5.6 \mathrm{~cm} ; \mathrm{W}$ : $1.7 \mathrm{~cm}$. (Inv. no. M6-2009.A2.433.1).

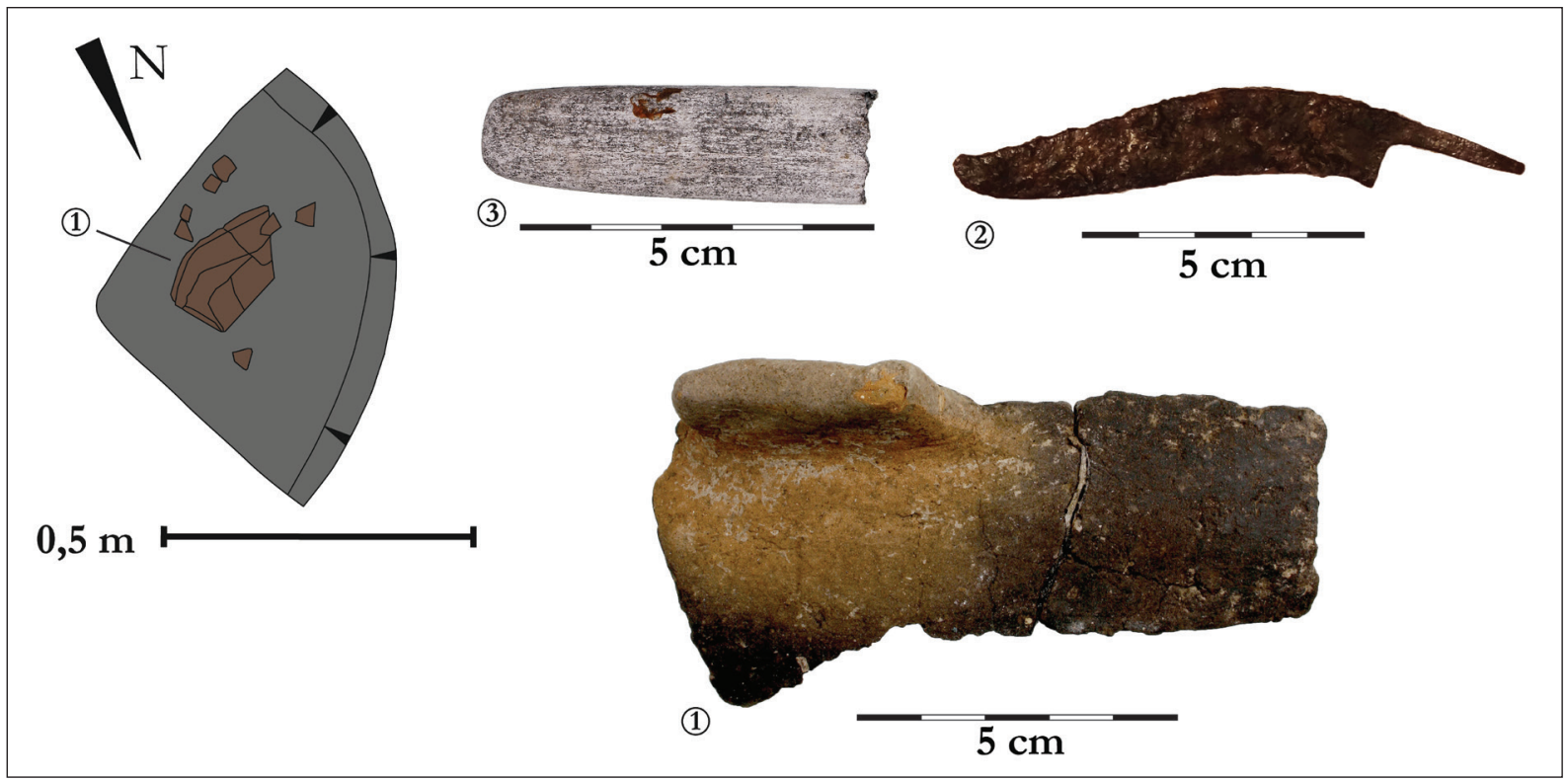

Fig. 22. Grave no. 16.

\section{Grave Finds}

\section{Fibulae}

\section{Certosa fibulae}

The Alsónyék cemetery yielded 10 bronze Certosa fibulae in total (Fig. 23). Nine of them remained to be more or less intact, one piece, however, is represented only by small fragments. The brooches that are in good condition have a length between 5.3 and $6.7 \mathrm{~cm}$. Despite the more or less disturbed state of the graves, it seems reasonable to assume that the bronze fibulae were probably worn on the upper part of the chest (see Grave no. 2: Fig. 5). Based on their main typological characteristics it is beyond doubt that all of them can easily be assigned to B. Teržan's Type $\mathrm{V}^{4}$ and thus, it is hardly surprising that their overall shape is relatively homogenous, they mostly differ only by the form of the bow's arch. Also, a distinction can be made between fibulae with the spring placed on the left or the right side, which certainly indicates 
Bence Soós
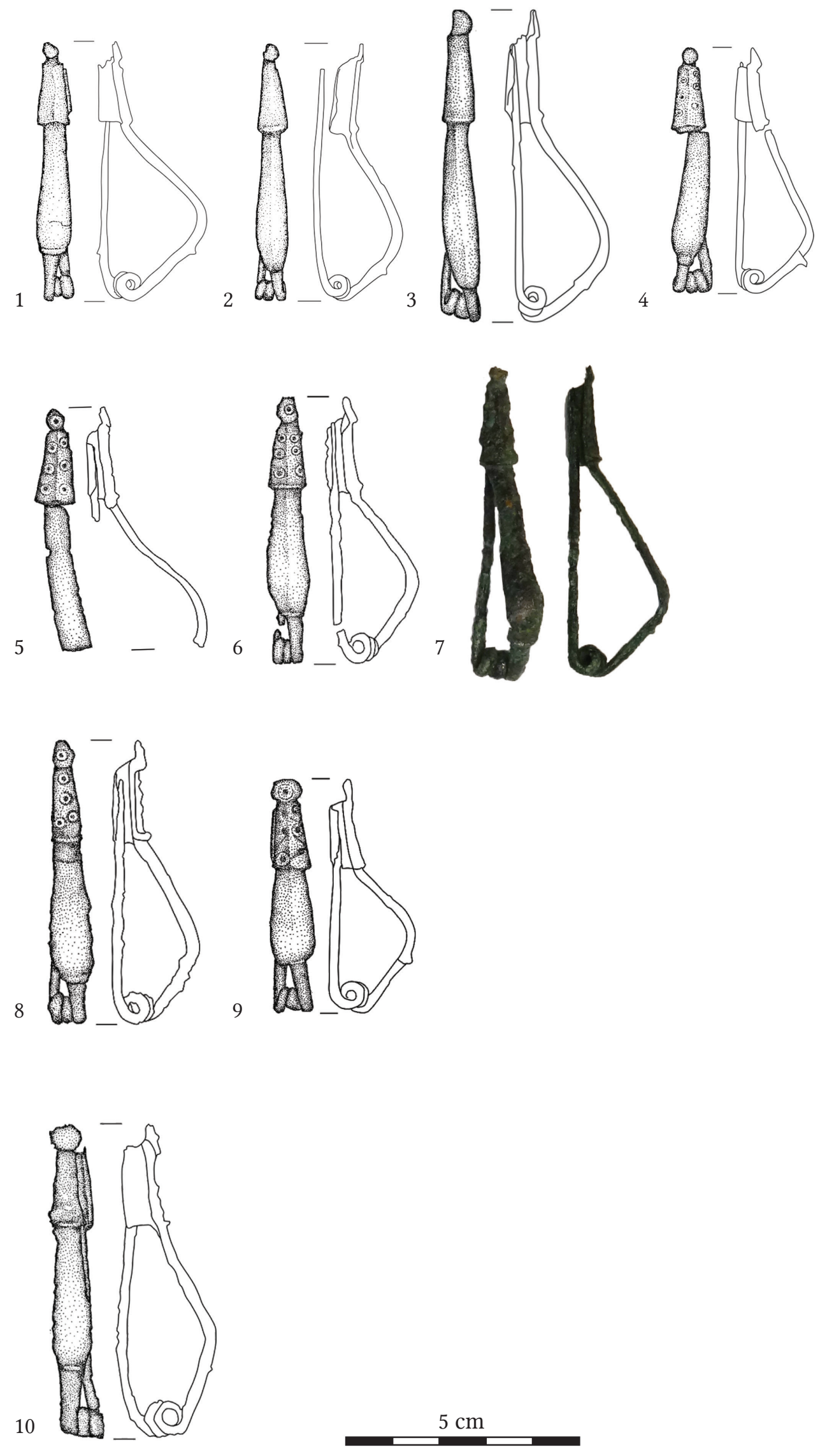

Fig. 23. The Certosa fibulae of Type V of the Alsónyék cemetery. 1-4 - Grave no. 2, 5-7 - Grave no. 8, 8-9 - Grave no. 11, 10 - Grave no. 15.

66 
that the brooches were commonly worn in pairs. In fact, this is attested by Grave no. 2 in the case of the Alsónyék cemetery. Moreover, cemeteries of today's Slovenia yielded several examples supporting this observation. ${ }^{5}$ There, fibulae of this type occur in the context of both male and in female burials, however, as S. Tecco Hvala highlighted, while women seem to have worn Type $\mathrm{V}$ brooches in combination with fibulae of other types, Certosa fibulae of Type V are more likely to be found in pairs in graves of men. ${ }^{6}$ In contrast, fibulae of Type V found in burials of the Alsónyék cemetery only occur in combination with brooches of the same type. The assemblage found in the Szárazd-Gerenyáspuszta grave, generally considered a female burial, also contained two fibulae of the type under consideration, however, these were accompanied by two animal-headed fibulae. ${ }^{7}$ Similarly, the Type V brooches of Grave no. 2 of the Beremend site were also found in combination with two Novi Pazar type silver fibulae. A more detailed evaluation of the chronological significance of these fibulae is provided in a later section of this paper.

The area of the fibulae's distribution stretches from Etruria to the Iron Gate (Fig. 24). Not surprisingly, they appear most frequently in grave contexts of the Dolenjska group in today's Slovenia, where their emergence dates to the first phase of the Certosa horizon, ${ }^{8}$ in absolute terms the second half of the 6th century BC. ${ }^{9}$ Also, their production continued in the subsequent Negova horizon. Their map of distribution clearly suggests that the commu-

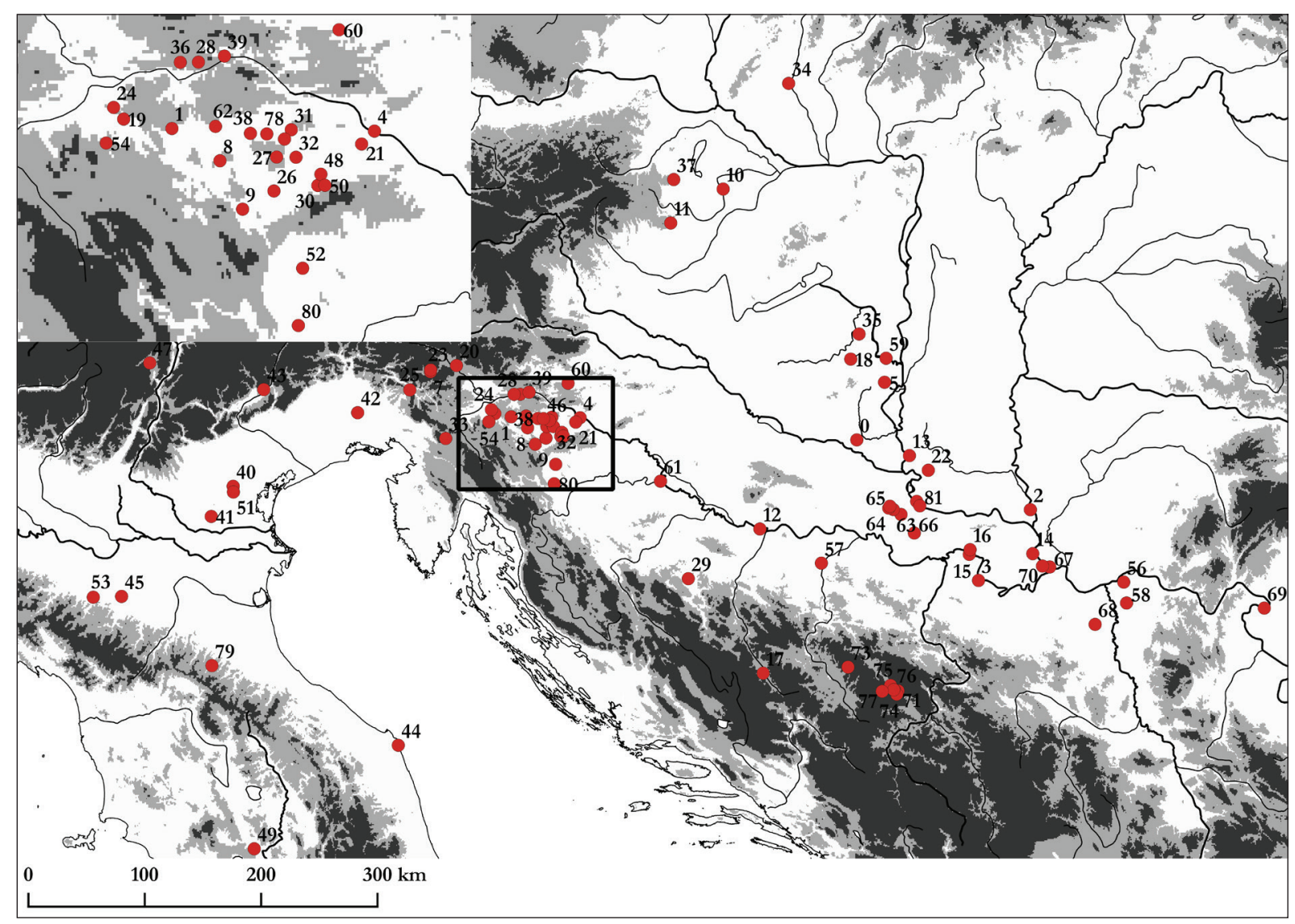

Fig. 24. The distribution of Certosa fibulae of Type V.

5 Tecco Hvala 2012, 250; Tecco Hvala 2017, 55.

Tecco Hvala 2012, 250.

MÁrTon 1933, 17.

Teržan 1977a, 391; Gabrovec 1987a, 67; Dular 2003, 136; Tecco Hvala 2012, 247.

TERŽAN - ČREŠNAR 2014, 719. 
nities along the Sava River played an essential role in transmitting them to southern Transdanubia, eastern Slavonia and the Srem district. The waterway could very well have played similarly significant role in transmitting other goods and ideas as well, hence the term 'Sava corridor' in recent literature. ${ }^{10}$

\section{Iron fibulae}

Arguably, the fragmentary iron fibulae found among the grave goods of Grave no. 1 are all specimens of the same type (Fig. 3.3-6), in spite of the fact that given the poor preservation of the items the exact type itself is hardly determinable. Both pairs of fibulae lay on either side of the upper part of the chest. As a result, these and the bronze fibulae might indicate that the people who used this cemetery generally wore their fibulae on their upper chest. As a matter of fact, this observation is also attested by the specimens found in graves of the Szentlörinc cemetery, ${ }^{11}$ indeed these are the closest analogies of the ones found in Grave no. 1 of the Alsónyék cemetery.

The largest Late Hallstatt graveyard of the region between the Sava and Kapos rivers yielded several examples of crossbow fibulae made of iron. Unfortunately, these are also of rather poor preservation and cannot be assigned to specific types, but fortunately they appear in combination with easily recognizable fibula variants that can be dated more accurately. ${ }^{12}$ Most of them occurs in graves with different variants of the Certosa 13 type according to B. Teržan's classification. In Grave no. 15 there was a Certosa 13h type brooch complementing the assemblage of attire elements which also included two iron crossbow fibulae. In the latest assessment of this variant M. Dizdar emphasised that specimens of this particular variant are most likely the products of workshops in the region between the Kapos and Sava rivers. ${ }^{13}$ He dates these brooches to the last quarter of the $5^{\text {th }}$ and to the first quarter of the 4th century, which might serve as a solid starting-point in dating the iron fibulae in the southern part of Transdanubia. However, considering that in Grave no. 29 of the Szentlörinc cemetery such a fibula was found in the same context with a Certosa 13c type brooch and taking into account that in today's Slovenia the appearance of iron crossbow fibulae is conventionally dated to the beginning of the Negova horizon, earlier dates (second half of the 5th century BC) cannot be ruled out. ${ }^{14}$ Similarly, the so-called bird-headed fibulae (Vogelkopffibel) found for instance in Grave no. 40 of the Szentlörinc cemetery indicates that such crossbow fibulae made of iron were still in use during the first half of the 4 th century BC. ${ }^{15}$

Similar fibulae came to light during the excavations of the Vinkovci-Nama ${ }^{16}$ and Szeged-Kiskundorozsma ${ }^{17}$ cemeteries, however, they cannot be dated more accurately than the ones found in Szentlörinc. It is worth noting however, that these sites share the lack of Certosa brooches of Type $\mathrm{V}$ in their assemblages, which seems to indicate that these iron crossbow fibulae were possibly in use later than the aforementioned Certosa type.

GuŠtin - TeržAn 1977, 80; TeržAn 1998, 521; Dular - Tecco-Hvala 2007, 232; Blečić Kavur - JašArević 2016, 226; JAŠAREVIĆ 2017, 11.

11 Jerem 1968, Fig. 7; Fig. 8.

12 Grave 15: Jerem 1968, Fig. 21,15/3-4; Grave 19: Jerem 1968, Fig. 21,19/11; Grave 33: Jerem 1968, Fig. 24,33/2-4; Grave 35-36: Jerem 1968, Fig. 24,35-36/3-4; Grave 38: Jerem 1968, Fig. 25,38/2; Grave 39: Jerem 1968, Fig. 25,39/1; Grave 43: Jerem 1968, Fig. 25,43/2-3; Grave 59: Jerem 1968, Fig. 28,59/2-3; Grave 67: Jerem 1968, Fig. 29,67/4-8. DizDAR 2015, 49.

14 Tecco Hvala 2012, 256.

15 Jerem 1968, Fig. 25,40/3-4; PARzinger 1989, 107.

16 Majnarić-Pandžić 2003, Abb. 5-6.

17 Pilling - UjvÁRi 2012, Pl. 9,2-3. 


\section{Belts}

Astragal belts

It is beyond doubt that one of the most characteristic types in the southern part of the Carpathian Basin in the latest phase of the Hallstatt Age are the so-called astragal belts. ${ }^{18}$ The excavation of the Alsónyék cemetery revealed three graves (Grave no. 2, no. 6, and no. 7) the assemblages of which included segments of astragal belts. These are all situated in the eastern part of the hitherto known extent of the cemetery among the graves which seem to form a relatively dense group within the graveyard. It is noteworthy that complete sets of astragal belts like the ones found in the graves discovered near Paks-Gyapa, Tolna-Mözs, Szárazd-Gerenyáspuszta, or Adaševci were not found. In fact, Grave no. 7 only contained one single bronze segment of a belt (Fig. 7.B). Interestingly, not just further elements of the grave goods but the human remains were also entirely missing. There is a number of possible scenarios behind this phenomenon but this question shall be addressed later.

As for Graves no. 2 and no. 6, the irregular scattering of both the human remains and the grave goods indicates that these burials might have been victims of severe disturbance or even plundering. Given the fact that intact or presumably intact astragal belts, such as the ones discovered near the above listed sites and several others, comprised over a hundred bronze articles, it is reasonable to assume that a large number of segments of the originally complete belt set might have been removed from the grave pit. The situation observed in Grave no. 2 firmly supports this scenario (Fig. 4). It is clearly visible on both the photographs and the drawings made of the grave, that the majority of the remaining belt segments scatter around the pelvis area and some of them might have actually been found in situ. As a result, one can argue that the belt was either wrapped around or rolled up and placed onto the waist of the deceased. Although, the reconstruction of Grave no. 1 of the Beremend cemetery suggests otherwise, ${ }^{19}$ considering the well-documented examples of Tolna-Mözs ${ }^{20}$ and Pilatovići ${ }^{21}$ it is more than likely that astragal belts were normally placed near or around the deceased's waist for the funeral.

While the general view about the astragal belts is that they were parts of women's attire, ${ }^{22}$ the current evidence supporting this idea is rather poor given the fact that anthropological evaluation of the human remains associated with such belts is completely absent. The currently discussed cemetery alters this situation only modestly due to the highly fragmented anthropological material recovered from the graves. Bearing this in mind, however, it is worth pointing out that the anthropological analysis of the remaining bones of Grave no. 6 concluded, although with certain doubt, that the deceased bore rather masculine than feminine morphological traits (see Appendix).

From a typological point of view, all segments found in the graves of the Alsónyék cemetery belong to the so-called Osijek variant of the Srem type according to the classification recently

Todorović 1965, 45; ГАРАШАНИН 1973, 513; АРСЕНИJЕВИЋ 1998, 9; Filipović - Mladenović 2017, Karta 2; DizDAR - TONC 2018, 48

19 JEREM 1973, Abb 3.

20 GAÁl 2001, 27-28.

21 Jevtić 2016b, Fig. 2.

22 АрсеНИJеВИЋ 1998, 23; Jovanović 1998, 39; Dizdar 1999, 39; Filipović - Mladenović 2017, 162; DizdAR ToNC 2018, 49. 
developed by V. Filipović and O. Mladenović. ${ }^{23}$ Actually, this is hardly surprising given the fact that all Middle Iron Age astragal belt segments from Transdanubia belong to the same type. The distribution map of the specimens of the Osijek variant indicates that the main production area of these belt segments was located in the Srem district (Fig. 25). The name of this region reoccurs in the typological classification of the Late Iron Age belt clasps put forward by S. Arsenijević. In the author's framework the Srem type comprises the characteristic three-loop clasps frequently appearing with astragal belts. ${ }^{24}$ They have a very small variability in form but their decoration is relatively diverse. The specimen found in Grave no. 2 bears twisted decoration on the loops and similar decoration appears along both longer edges of the belt plate, but the inner field of the plate itself is unornamented. The claps found near Uzveća bears similar twisted decoration on the loops and along the edges, but contrary to the Alsónyék specimen its plate has incised point-circle mo-

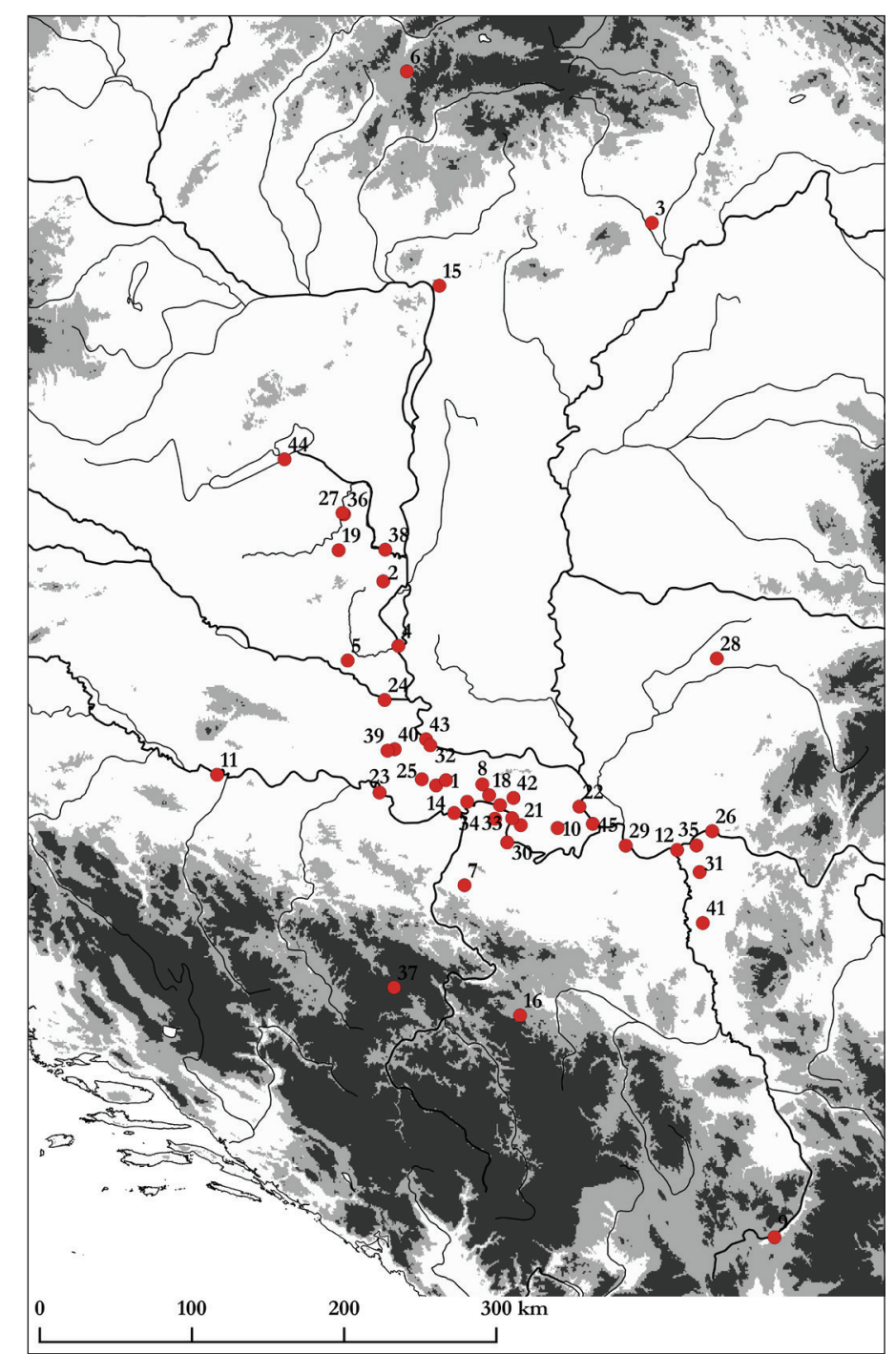

Fig. 25. The distribution of specimens of the astragal belts' Osijek variant (after Filipović - Mladenović 2017, with supplements) tifs. A further noteworthy example is the an astragal belt found in 1907 near Novi Sad which has twisted decoration on its loops but not on the plate's edges. ${ }^{25}$ However, considering the decoration of the specimen the clasp found among the grave goods of Grave no. 1 of the Beremend cemetery resembles it the most. ${ }^{26}$ In fact they are nearly identical in terms of decoration.

\section{Belt clasp with a central bar and bronze belt mounts}

In the context of the cemetery under consideration, or better to say the hitherto excavated part of the graveyard, Grave no. 15 seems to be out of-the ordinary for several reasons. One of these reasons is the belt set (Fig. 21.4-7), elements of which were scattered around the waist of the deceased (Fig. 20). As discussed above, as far as the region between the Kapos and Sava 
rivers is concerned, astragal belts can certainly be considered the most characteristic type of belt sets in the Middle Iron Age. Although belt clasps with a central bar are not unprecedented in the southern part of Transdanubia, they are definitely not among the most characteristic nor the most frequently occurring types of attire elements in the Middle Iron Age of the region in question.

Belt hooks similar to the bronze specimen found in Grave no. 15 came to light from graves of the Szentlörinc cemetery. ${ }^{27}$ However, in contrary to the piece discussed here, they are all made of iron, and hence, their current condition is considerably worse which makes it impossible to reconstruct their original shape and decoration with sufficient certainty. Interestingly, set aside these examples, specimens of this type of belt clasps are absent from the materials of the Middle Iron Age sites in southern Transdanubia, eastern Slavonia and in today's northern Serbia.

Closely similar artefacts appear in funerary contexts in the north-western Balkans, chiefly in today's Bosnia and Herzegovina and in the southern Alpine region, in today's Slovenia. Although, they are all characterised by a pronounced central bar running along the longitudinal axis of the plate of the clasp, their shape, design, and construction shows great diversity.

In fact, as far as their shape and production technology are concerned, there are five main variants of the type, and it is hardly surprising that they all appear in the Iron Age archaeological material of today's Slovenia. To begin with, the cemetery near Most na Soči yielded several examples of a variant whose characteristic features are their relatively large length, their long hook and the four rivets in the four corners of the plate of the clasp. ${ }^{28}$ In addition, all examples are made of bronze and only one end of the central bar terminates in a hook. Based on Grave no.740 of the Most na Soči cemetery, the emergence of this type in the area of today's Slovenia probably dates to the IIb phase of the Sv. Lucija group..$^{29}$ It is important to note that S. Gabrovec already highlighted the fact that these belt claps mainly appear in male graves, which also applies to other belt types with a central bar.

The distribution of specimens of this variant does not confine to the cemetery of Most na Soči. Similar belt clasps came to light in northern Italy ${ }^{30}$ and at sites east of the Soča River (Fig. 26.A). A specimen bearing all characteristic features of the variant was found among the finds of Tumulus no. 6 in the cemetery excavated near Dobrava. ${ }^{31}$ Unfortunately, its exact context is unknown, consequently, it can only be dated in broad terms. According to V. Stare the erection of the tumulus cannot precede the Ha D period. ${ }^{32}$ The Mecklenburg Collection also holds a specimen which was probably found in today's Slovenia, but its exact provenance and dating are unknown. ${ }^{33}$

Recently, D. Božič and his colleagues defined another variant which they call Kovk type belts and which seems closely related to the above discussed variant. Their characteristics are the triangular ending of the belt plate, the numerous small hooks along the longer sides of the

27 Grave 6: Jerem 1968, Fig. 19,6/2; Grave 31: JEREM 1968, Fig. 24,31/3.

28 Gr. 587 (TeržAn et al. 1985, T. 50,587/6); Gr. 740 (TeržAn et al. 1985, T. 73,740/3); Gr. 1564 (TerŽAN et al. 1985, T. 136,1564/2); Gr. 1656 (TeržAN et al. 1985, T. 156,1656/6); Gr. 890 (MARCheSETTi 1993, T. 26,3); Gr. 1202 (Marchesetti 1993, T. 26,4); Gr. 776 (Marchesetti 1993, T. 26,5); Gr. 1746 (Marchesetti 1993, T. 26,6).

29 Gabrovec 1987b, 132.

30 For instance, in Este (Frey 1969, T. 33,30).

31 StARE 1973b, T. 9,9.

32 StARE 1973b, 747.

33 Dobiat 1982, T. 13,1. 
plate, and finally their outstandingly rich decoration. A specimen of this variant was found among the grave goods of Grave VII/1 near Brezje, which can be dated to the late Certosa period based on the grave goods, especially the animal-headed fibula and the torques. ${ }^{34}$ At the eponymous site, two burials came to light recently, one of which yielded an exceptional belt set including a clasp resembling the specimen from Brezje as well as a Negova helmet, an iron socketed axe, an iron knife and allegedly an iron spearhead. ${ }^{35}$ The resemblance between the belt clasp from Brezje and Kovk led the authors of the publication of the Kovk finds to conclude that the latter also dates to the younger phase of the Certosa period, and the grave itself in which it was found, based on the Negova type helmet of the Vače group, to the early phase of the subsequent Negova period. ${ }^{36}$ In addition, there is an example of this variant which was found in the Ljubljanica River near Vhrnika. ${ }^{37}$

Grave IV/3 of the Novo mesto-Kandija cemetery is one of the most spectacular Early Iron Age graves in today's Slovenia. The double burial of a female and a male is a typical example of

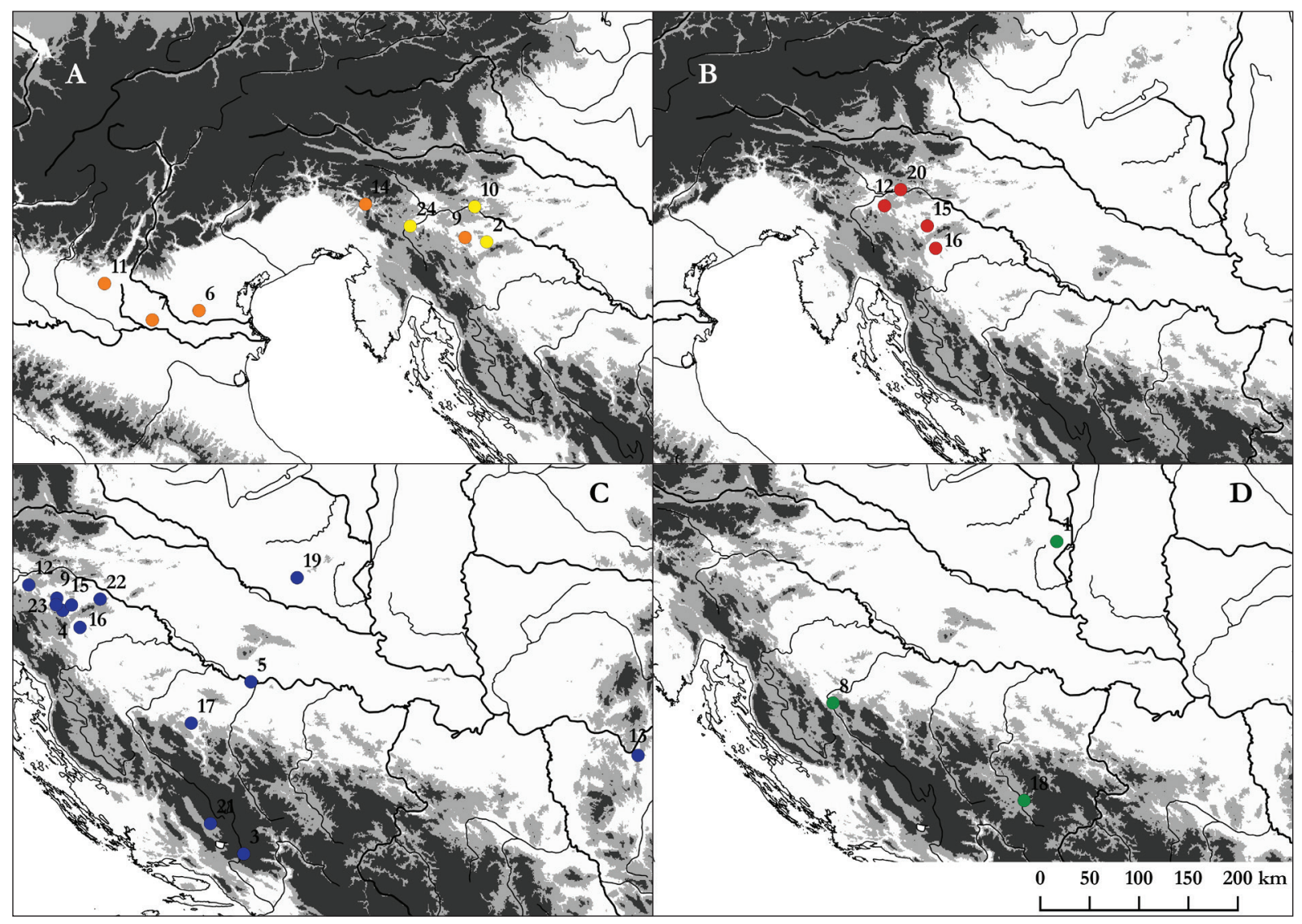

Fig. 26. Distribution map of the belt clasps with a central bar. A - Type Most na Soči (Orange), Type Kovk (Yellow), B - Type Novo Mesto, C - Type Sanski most, D - Type Jezerine. 1 - Alsónyék, 2 - Brezje, 3 - Crvenica-Ritke Liske, 4 - Dolenjske Toplice, 5 - Donja dolina, 6 - Este, 7 - Jezerine, 8 - Korita, 9 - Kovk, 10 - Lonato, 12 - Magdalenska gora, 13 - Miroč Mountain, 14 - Most na Soči, 15 - Novo mesto, 16 - Podzemelj, 17 - Sanski most, 18 - Semizovac, 19 - Szentlőrinc, 20 - Vače, 21 - Vašarovine, 22 - Vinji vrh, 23 - Vinkov vrh, 24 - Vrhnika. 
the Negova phase in the Dolenjsko region. ${ }^{38}$ During the excavation of this grave an in situ belt set including a clasp made of bronze with a central bar was recovered. ${ }^{39}$ This, however, differs significantly from the Most na Soči variant discussed above. Contrary to the specimens of that variant, in this case the central bar was cast separately from and subsequently riveted to the vertically slightly bent belt plate, also it ends in a hook on both ends. In addition, each of the rivets fixing the central bar bears a ring. Furthermore, the length of the hook is considerably smaller than those of the belts of the Most na Soči variant. The belt plate and the bar are richly decorated with punched circles and incised lines. Based on the radiocarbon analysis conducted on a tooth of the horse also found in the grave dates the burial to the first half of the 4th century BC. ${ }^{40}$

It is important to note that the grave goods depict the man interred in the grave as a warrior of exceptionally high status. ${ }^{41}$ This seems to be a recurring feature of the graves containing belt clasps of the Novo mesto variant. ${ }^{42}$ The armament in Grave IV/3 consists of a Negova type helmet, a socketed axe, iron spearheads and the belt set. ${ }^{43}$ Similarly, in the case of Grave I/23 of the same cemetery the equipment of a warrior came to light comprising a double crested helmet, a socketed axe, adzes, iron spearheads, arrowheads as well as a belt set including a belt clasp with a central bar very similar to the one discussed above, but here even the rings bear decoration ${ }^{44}$ In this case, however, it is only possible to date the assemblage in broader terms. Namely, there is only one fibula fragment among the finds, possibly a Certosa type brooch, but the variant it belongs to is not determinable..$^{45}$ In terms of chronology, the double crested helmet is the most reliable evidence which dates the burial to the Certosa horizon. ${ }^{46}$ In other words, this grave most likely is somewhat older than Grave IV/3.

Unfortunately, no further examples from such reliable contexts are currently known. One specimen was found in Tumulus no. 5 at the Preloge cemetery, reportedly together with two iron spearheads and a bronze vessel, but the exact context of the items is undocumented. ${ }^{47}$ Similarly, the specimen found near Podzemelj has to be considered as a stray find. ${ }^{48}$ Finally, there are two hitherto unpublished specimens of the Novo mesto variant, one of them currently held in the Hungarian National Museum allegedly from Vače ${ }^{49}$ and another from Kope nad Kompoljami (Fig. 26.B). ${ }^{50}$

Let us now turn to the fourth variant (Fig. 26.C). At several sites of the Dolenjska group there were belts showing the basic characteristics of the type but instead of bronze they were made of iron. In addition, they lack decorative elements such as the rings the specimens of the Novo

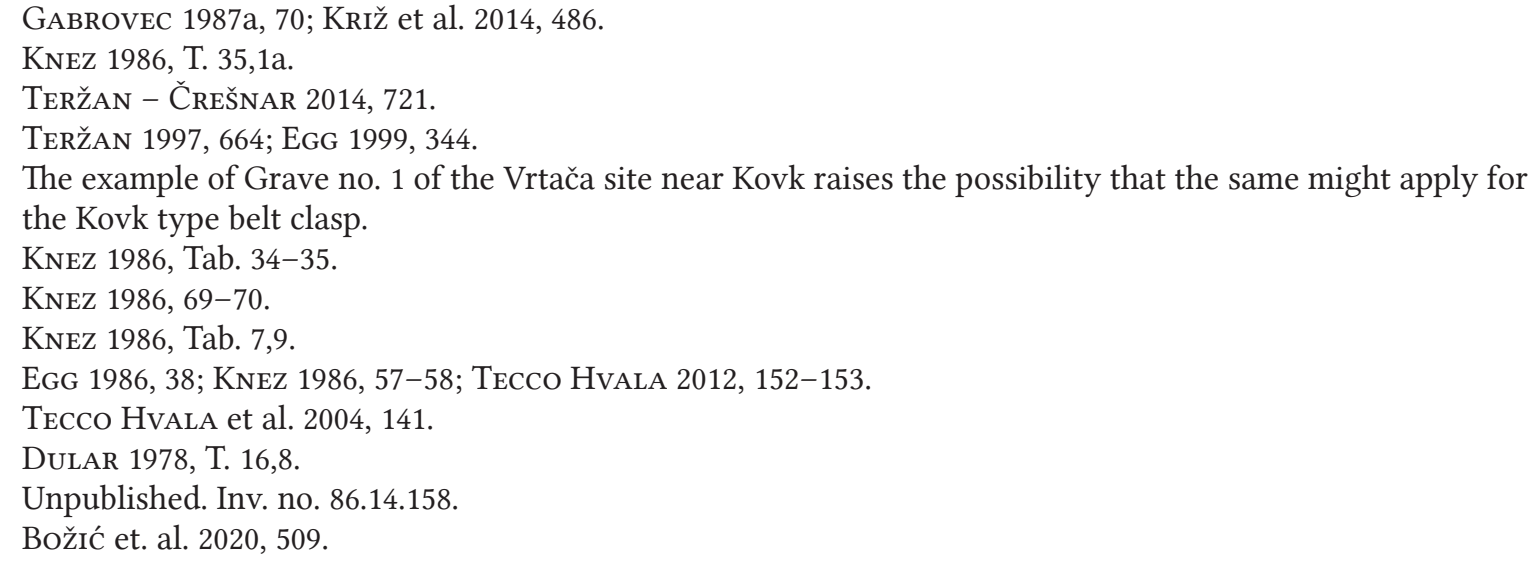


mesto variant bear, and in contrast to the ones from Most na Soči their central bar extends beyond the edge of the belt plate on both sides. Also, it is very important to note that while the distribution of the variants discussed above does not extend east of today's Slovenia, however, the distribution of the specimens of the third variant does. Unfortunately, in many cases these iron belt clasps are in poor state of preservation due to corrosion.

However, I would like to start with the instances in the Dolenjska region. Set aside the lack of decorative elements, due to its slender form the specimen found in Grave VII/ $/ 8^{51}$ of the Dolenjske Toplice cemetery is to some extent similar to the specimens of the Novo mesto variant, and this in general applies for most of the examples of this variant. Based on the Certosa 13c type fibula and the fact that the interments in Tumulus VII stopped at the beginning of the Negova horizon, B. Teržan dated the burial to the Certosa horizon..$^{52}$ The same cemetery yielded another piece, but in considerably worse condition..$^{53}$ Unfortunately, since items allowing a precise dating are missing from this context, the specimen's age can only be determined in broad terms. Based on the so-called Koppelringen probably belonging to the belt set, the author dates this grave to the Negova horizon. ${ }^{54}$

It is worth pointing out that these two graves both contained weapons, namely iron spearheads, which also indicate a strong link between belts clasps with a central bar and weapons. This is also supported by the pieces found in the Kandija cemetery in Novo mesto. The assemblage found in Grave III/24 included a belt set comprising of a belt clasp, several belt mounts made of iron and a fragmentary iron spearhead..$^{55}$ Similarly, among the finds unearthed in Grave II/2 there was an iron spearhead accompanying a rather complex belt set. ${ }^{56}$ Given the Certosa 12 type brooches among the finds in the latter grave, the assemblage can be dated to the very end of the Late Hallstatt Age of the Dolenjska group, and hence this example indicates the relatively broad time frame of this tradition.

Unfortunately, further specimens of the variant in today's Slovenia mainly appear in uncertain and unreliable contexts. The belt clasps found near Veliki Vinji vrh and a further piece from Podzemelj are stray finds. ${ }^{57}$ The examples found in the Magdalenska gora ${ }^{58}$ and Vinkov $\operatorname{vrh}^{59}$ cemeteries should also be regarded as stray finds because their exact context within the tumuli is undocumented.

Examples of this variant corresponding by and large to Type 6 in S. Arsenijević' classification ${ }^{60}$ appear in western Bosnia and Herzegovina, in Central Dalmatia and in southern Transdanubia during the 5th century BC. ${ }^{61}$ There are several examples among the finds of the Sanski most cemetery. Not surprisingly, here they are also frequently associated with weapons. ${ }^{62}$ The burial

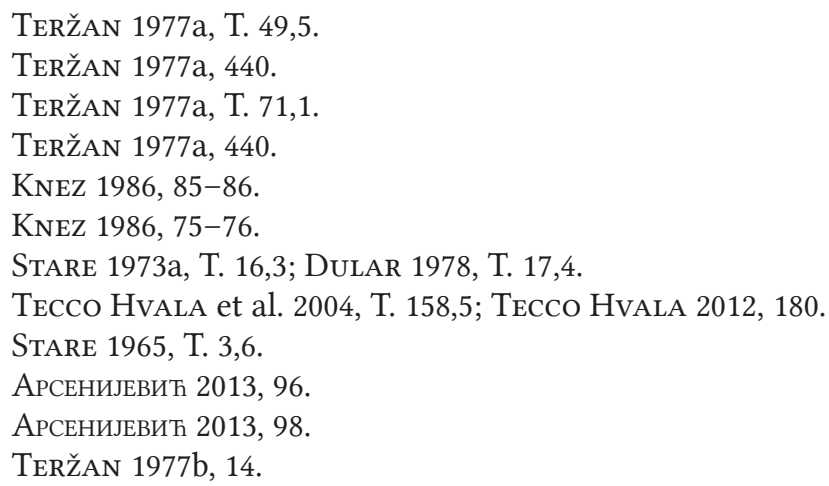


assemblage in Grave no. 4 included a relatively large iron spearhead, a battle knife, a whetstone and an iron belt clasp of the variant in question. It is worth mentioning that the central bar of this specimen was decorated with horizontal lines. ${ }^{63}$ The composition of the grave goods in Grave no. 12 showed a similar picture, but there were two belt clasps with noticeable differences. ${ }^{64}$ One shows the typical traits of the variant under discussion, but the other is slightly different in terms of shape and design. It has a slightly ovoid form and the rivets fixing the central bar are clearly visible. ${ }^{65}$ Unfortunately, these graves cannot be precisely dated within the Late Hallstatt Age.

The examples from Donja dolina also support the aforementioned link between belt clasps with a central bar and weapons. Grave no. 24 at Greda M. Petrović mlađeg contained two iron spearheads, a large battle knife, a casting mould and an iron belt clasp, ${ }^{66}$ an assemblage notably similar to the ones discussed above, unearthed at Sanski most. According to Z. Marić the burial dates to phase IIc of the relative chronological system she developed for the Donja dolina cemetery. Also, she emphasised that belt clasps of this type serve as evidence for the contacts between the communities of the Dolenjska and Donja dolina-Sanski most groups, ${ }^{67}$ an assumption supported later by B. Teržan and S. Arsenijević. ${ }^{68}$

Let us now turn to the Szentlörinc cemetery where two iron belt clasps with a central bar came to light. Interestingly, in terms of shape they resemble the one found among the grave goods in Grave no. 12 of the Sanski most cemetery, namely they have a slightly ovoid shape, ${ }^{69}$ though, contrary to the latter, their central bar is less pronounced. Similarly to the Sanski most example, the above-mentioned pieces from the Szentlonrinc cemetery were both associated with weapons in the burial context. In Grave no. 6 there was an iron spearhead, while Grave no. 31 also contained an iron arrowhead beside a spearhead. The latter grave also yielded an iron belt buckle ${ }^{70}$ analogies of which emerged in the territory of north-western Bosnia and Herzegovina approximately simultaneously with the appearance of early La Tène types, that is, in phase $3 \mathrm{~b}$ of the chronological framework of B. Čovic..$^{71}$

There are two further examples from the hinterland of the Dalmatian coastal region. Unfortunately, determining the exact chronological position of the two iron belt clasps with a central bar is a perplexing task owing to the fact that they came to light in mass graves. ${ }^{72}$

One of the most important discoveries of recent years showed that Szentlonrinc is not the easternmost point of the distribution of the variant under discussion. In the Miroč Mountain a large hoard of iron objects came to light among unknown circumstances. Among the finds there were several iron belt clasps with a central bar in some cases decorated with horizontal grooves. ${ }^{73}$ Unfortunately, the exact dating of the find is uncertain, but given the situation's

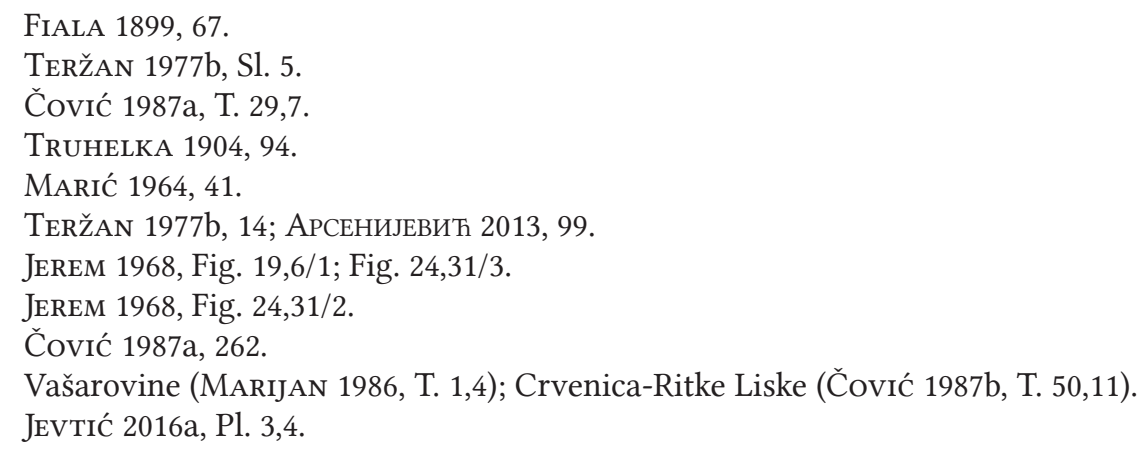


resemblance to the distribution of the so-called Donja dolina type pins, ${ }^{74}$ it might be seen as evidence for the contacts over exceptionally large distances along the Sava and Danube Rivers.

Of course, in the regions east of the area of today's Slovenia there exist bronze belt clasps with a central bar (Fig. 26.D). In fact, in terms of shape and design they are closely related to the specimens made of iron. One of the most prominent examples is a piece included among the finds of Grave no. 59 of the Sanski most cemetery. It has a rectangular plate and a central bar made of bronze held together by two rivets. The central bar is decorated with densely placed incised lines and X motifs. Not surprisingly, the assemblage included an iron spearhead as well as an iron battle knife. In addition, there was a double pin among the finds, which enabled B. Čović to date the assemblage to phase $3 \mathrm{a}-2$ in his system. ${ }^{75}$ It is worth highlighting that Certosa fibulae of Type $\mathrm{V}$ are among the characteristic finds of this phase. ${ }^{76} \mathrm{In}$ fact, this grave might provide help with determining the chronological position of the graves in the cemetery with iron belt clasps of this variant. Interestingly, though, this is not the best analogy to the belt clasp found in Grave no. 15 of the Alsónyék cemetery.

An example fairly similar to the one from the cemetery under discussion came to light from an unknown context in a fortified settlement near Semizovac. ${ }^{77}$ B. Čović assumed that the specimen was part of a grave assemblage and dated it to phase 5 of the so-called central Bosnian group. The beginning of this phase is marked by the appearance of the Certosa type fibulae in the region. ${ }^{78}$ Besides the incised decoration on the central bar, the specimen's relative shortness and the shape of the hook ${ }^{79}$ makes it considerably more similar to the piece from Grave no. 15 than the other examples of the type discussed above.

Also, a specimen found in Grave no. 235 of the Jezerine cemetery near Pritoka has to be mentioned. ${ }^{80}$ Based on its dimensions and design it is also a fairly similar item, especially considering that it ends in a hook on both sides. One apparent dissimilarity is that the shape of the belt plate is not entirely rectangular, namely it has one semi-circular extensions at each corner. As already mentioned several times, belt clasps with a central bar tend to occur in association with weapons among the grave goods in Dolenjsko, in the north-western Balkans and in southern Transdanubia. This is a notable exception because the urn grave yielded only one single object apart from the ceramic urn, this belt clasp. As a result, its chronological position is somewhat doubtful. Z. Maric dated the grave to phase 3 of the framework she proposed for the relative chronology of the Iron Age in the Una valley. ${ }^{81}$ The beginning of this phase is marked by the sporadic appearances of early La Tène fibulae and stylistic elements attributed to the early La Tène art. ${ }^{82}$

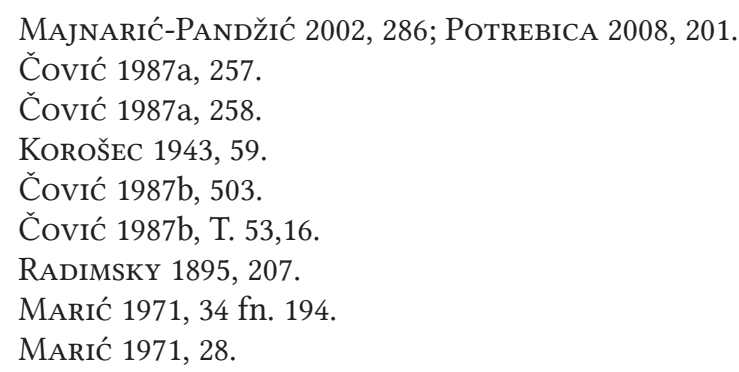




\section{Ring jewellery}

Temporal rings

It is beyond doubt that the most significant items among the grave goods of Grave no. 8 are the relatively large bronze spirals made of thin wire with twisted decoration and ending in a small spiral (Fig. 12.4-9). This type of jewellery is well-known even in southern Transdanubia given the fact that similar spirals were found both in the Beremend and Szentlörinc cemeteries. ${ }^{83}$ Although, the detailed documentation of the exact position of the finds within the grave is missing, E. Jerem assumed that the spirals made of thin twisted silver wire found among the grave goods of Grave no. 2 near Beremend were worn as bracelets. She also pointed out that similar items predominantly occur in southern regions. ${ }^{84}$ Indeed, similar pieces of jewellery came to light in relatively large amounts from the Donja dolina cemetery. Most of them can be dated to phase IIc in terms of Z. Marić' relative chronological framework, ${ }^{85}$ or to phase $3 \mathrm{a}-1$ in B. Čović's system. ${ }^{86}$ In other words, their chronological position is to some extent synchronous with the proliferation of Certosa fibulae in today's northern Bosnia. It is important to note that in contrast to the specimens from Beremend, the spirals found in the Donja dolina cemetery are almost exclusively made of bronze, and thus represent closer analogies to the ones among the grave goods of Grave no. 8 in Alsónyék. In fact these items helped to reconstruct the ring jewellery in Grave no. 8 as spirals, which had not been obvious due to their fragmentary state.

It is worth mentioning that Z. Marić and other scholars from Bosnia do not refer to these items as bracelets. The reason behind this is simple: Č. Truhelka, leader of the Donja dolina excavations, managed to document the spirals' relative position within the graves. According to him these adornments were usually located on both sides of the skull.${ }^{87}$ One example might be Grave no. 9 at Greda M. Petrović mlađeg, in which Certosa 5 and Certosa 2 type fibulae were found which suggest a fairly early dating within the Late Hallstatt Age for this grave, however, B. Čovic claimed this burial to be unreliable.$^{88}$ Nonetheless, a large body of evidence suggests that such spirals were already fashionable jewellery when the Certosa fibulae appeared along the middle course of the Sava River. ${ }^{89}$ On the other hand, however, the information currently above leads to the conclusion that temporal rings of this kind became an element of attire in southern Transdanubia with the appearance of the Certosa fibulae in the same region.

Interestingly, there are similar spirals among the items found in the graves of the Sanski most graveyard, although they are not as common as in Donja dolina..$^{90}$ Based on the Certosa $13 \mathrm{c}$ type brooches, the specimen in Grave no. 17 can be dated to the $3 \mathrm{a}-2$ and $3 \mathrm{~b}$ phases according to B. Cović, that is, to the second half of the 5th century BC.$^{91}$ Likely, the spiral from Grave no. 122 might be dated to the same period. In contrast to the Donja dolina cemetery, where such 
spirals made of thin bronze wire tend to occur in graves in relatively large amounts, that is, 4-9 pairs, in Sanski most graves usually contained only one or two of these adornments. Also, F. Fiala mentions that they were worn on wrists. ${ }^{92}$ Another dissimilarity is that the spiral rings of the Sanski most graveyard lack the twisted decoration characteristic of the pieces found in the Riitešic mound dated to the second half of the 5th century BC. Both in terms of design and dating the specimen from Grave no. 9 of the Szentlörinc cemetery seems to be closely related to the specimens mentioned above, ${ }^{93}$ also according to the observation made during the excavation this item was found on the right forearm of the deceased. ${ }^{94}$

In spite of the fact that there are numerous instances where such spirals were arguably worn as bracelets, there may be no doubt that the ones found in Grave no. 8 of the Alsónyék cemetery follow the patterns seen in the case of the examples in the Donja dolina cemetery. The photos (Fig. 11) made of the burial clearly show how the fragments of the spiral rings were scattered around the damaged skull. As a result, despite the disturbance, we can confidently conclude that they were parts of some kind of headdress. Based on this example and the conclusion drawn about where the astragal belts were usually worn, one might argue that the reconstructions of the graves at Beremend can to some extent be misleading.

\section{Small bronze rings}

According to the general view about the Late Hallstatt Age of southern Transdanubia, the local elite and the communities, in general, began to establish strong ties with the communities living to the south as well as to the east. However, while the Alsónyék cemetery provides a large body of evidence for the former connection, so far there is only one single item suggesting that the people using the graveyard were ready to wear elements of attire of eastern taste. This object is a small spiral ring made of relatively massive bronze wire (Fig. 3.1). Based on its characteristic shape it is fairly obvious that the item belongs to one of the most common and recognizable types in the Carpathian Basin in the Middle Iron Age. These items are believed to have been produced by workshops of the communities forming the so-called Alföld group. ${ }^{95}$ In addition, according to general belief the specimens found in Transdanubian contexts can be seen as imports. ${ }^{96}$ According to Tibor Kemenczei's typological system the specimen found in Grave no. 1 can be assigned to Type $2,{ }^{97}$ however, one characteristic feature of these, the precious metal coating ${ }^{98}$ visible on several pieces of the type under discussion is completely missing in this case, although, one cannot rule out the possibility that this coating was worn off during the time the item was buried. ${ }^{99}$

Interestingly, the exact function of these objects is still under debate. While some scholars argue that they were worn as earrings, others consider them hair rings. ${ }^{100}$ In the case of Grave no. 1 the ring was found under the skull's left side. It was worn in pairs with a simple ring made of thin bronze wire the shape of which does not follow the characteristic traits of the type under

FiALA 1899, 115.

JEREM 1968, Fig. 20,9/3.

JEREM 1968, 162.

KemencZei 2009, 79; Kemenczei 2010, 118.

Kemenczei 2002, 57; Kemenczei 2009, 79; Schwellnus 2011, 368.

KemenCZei 2009, 80.

KemenCZei 2009, 80; Kozubová 2013, 27.

ILON 2017, 100.

KeMENCZei 2009, 79; ILON 2017, 97. 
discussion. The position of the rings within the grave pit and in particular their position in relation to the human remains are able to support both assumptions regarding the exact function of the rings. It is beyond doubt, however, that similarly to the cases documented in context of graveyards attributed to the Vekerzug culture, the rings were worn on the head by members of the population using the Alsónyék cemetery living to the west of the Danube River.

The examples uncovered in the area of the so-called Alföld group of the Vekerzug culture came from both inhumation and cremation burials. ${ }^{101}$ Based on the composition of other grave goods, some drew the conclusion that these rings were common elements of female attire. The grave assemblage and the anthropological analysis of the human remains found in Grave no. 1 tell a similar story. Interestingly, in the Szentlörinc cemetery a burial came to light which in terms of grave goods is very similar to the one under consideration. There were four crossbow fibulae, three of which were made of iron, very similar to the specimens discussed above found also in Grave no. 1. In addition, both grave assemblages contained several glass paste beads and a curved iron knife, which also signify the similarity between the two burials. Interestingly, the best analogy of the bronze ring of simple design (Fig. 3.8) found on the other side of the skull in Grave no. 1 also appears among the finds from another grave in the Szentlörinc cemetery. ${ }^{102}$ Given the Early La Tène fibula among the finds, this burial is dated to the latest phase of the graveyard, that is, to the first half of the 4th century BC. ${ }^{103}$

\section{Weapons}

\section{Spearheads}

Among the grave goods found in graves hitherto discovered at the Alsónyék site weapons seldom occur. Only two spearheads belong to this find category (Fig. 27). As earlier discussed, belt clasps with a central bar appear regularly in association with weapons. The specimen found in Grave no. 15 is no exception either. The other example comes from the one and only burial with scattered cremated human remains, namely Grave no. 14.

Iron spearheads are constant elements of warriors' equipment in Transdanubia from the second half of the Ha C period onwards. ${ }^{104}$ In general, multiple pieces tend to appear in each find context and they are usually accompanied by iron axes. ${ }^{105}$ It is worth pointing out that iron spearheads appear both in context of large tumuli and graves in so-called 'flat' cemeteries during the earlier phases of the Hallstatt Age. ${ }^{106}$ In addition, iron spearheads were standard elements of warriors' equipment in the areas lying south of the Mura River, ${ }^{107}$ and also played an important role in the north-western Balkans during the 6 th-4th centuries BC. ${ }^{108}$ In fact, while outlining the so-called warrior horizon of the 5th century, B. Teržan brought attention to the fact that iron spearheads were the main weapons in the region expanding from northern Italy to the central Balkans. ${ }^{109}$

101 KeMENCZEI 2002, 61.

102 JEREM 1968, Fig. 25,40.

103 Popović 1996, 106; Rustoiu 2012, 358-359.

104 Fekete 1985, 65; MetZner-Nebelsick 2002, 387.

105 TeržAn 1990, 266; MetZner-Nebelsick 2002, 386; EgG 2006, 47.

106 LENGYEL 1959, 166.

107 Tecco Hvala 2017, 156.

108 Benac - Čović 1957, 61; Chochorowski 1985, 101; Čović 1987a, 248; Blečić KAvur - JašARević $2016,230$.

109 TERŽAN 1977b, 13-14. 
The typological characterization of iron spearheads has never been an easy task for obvious reasons. ${ }^{110}$ Nonetheless, there are several noteworthy attempts at classifying them, even in cases chronologically related to the cemetery under consideration. A common characteristic of these attempts is that their focus lies on the ratios of different dimensions of the spearheads. M. Gavranović tried to distinguish basic variants among the Iron Age spearheads found during the excavations of the Donja dolina cemetery. ${ }^{111}$ Of the two spearheads found in the Alsónyék cemetery, only the one discovered in Grave no. 14 can be easily assigned to one of the types described by named author, namely to Type 2. The specimens belonging to this type are characterized by slender blades, a strong midrib and a relatively long socket. In the case of the Donja dolina cemetery, such spearheads appeared during the 7th century BC and were produced and used until the end of the 5th century BC. ${ }^{112}$ Based on its relatively slender shape, its strong

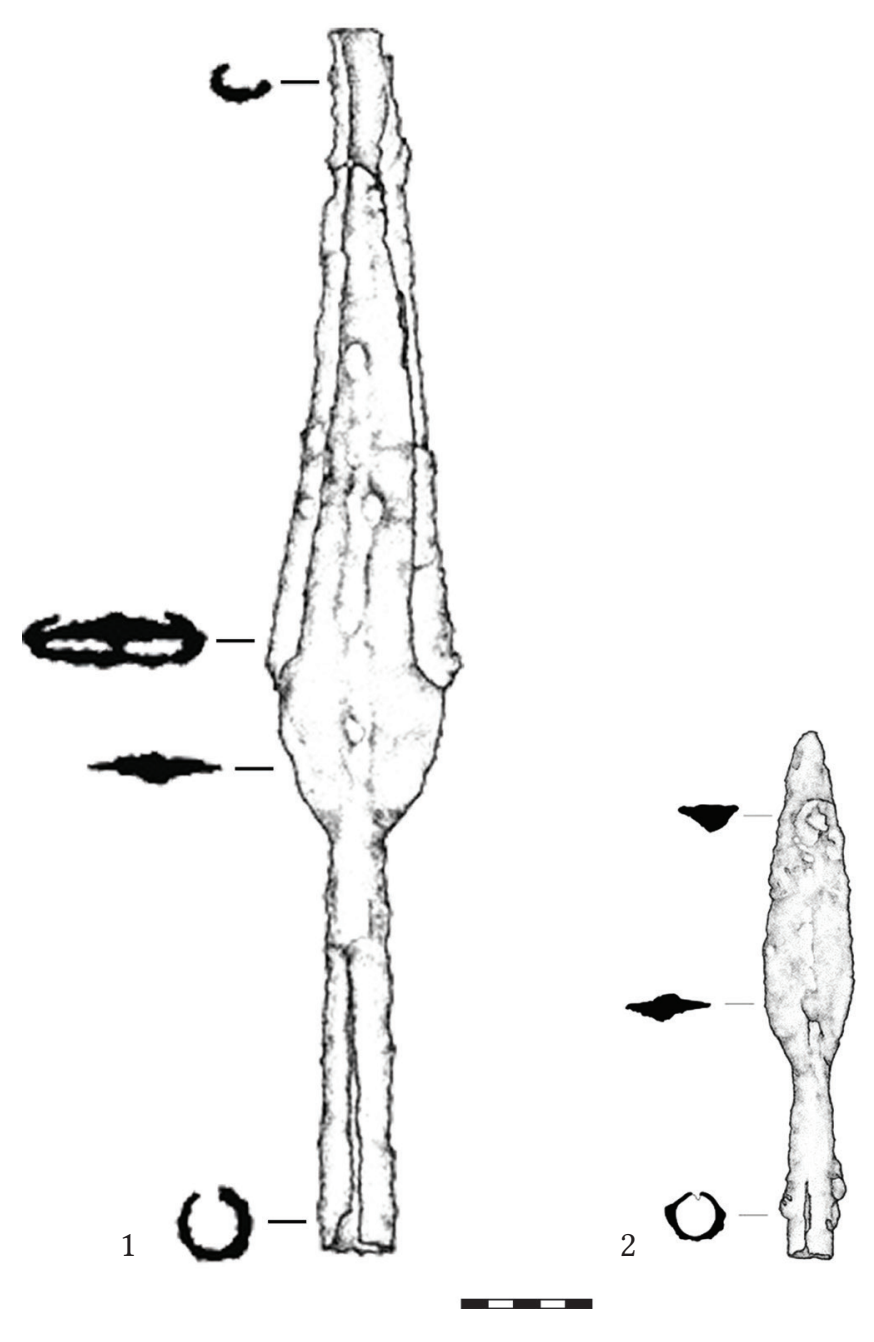

Fig. 27. Spearheads found in the cemetery. 1 - Grave no. 14, 2 - Grave no. 15. midrib and its length of more than 30 $\mathrm{cm}$, the specimen found in Grave no. 14 shows similarities with the spearheads of Type 1 in the system developed by A. Kozubová. ${ }^{113}$ In addition, in spite of its relatively small dimensions, the spearhead found next to the deceased interred in Grave no. 15 might also be assigned to this same type. As for the chronological position of the spearheads of Type 1, A. Kozubová, brought attention to the fact that most iron spearheads date to the periods corresponding with the Certosa and Negova horizons of the Dolenjska region. ${ }^{114}$

\section{Iron sheath}

Given the fact that iron sheaths are relatively common in the archaeological material of the period under consideration it is hardly surprising that a similar item was also found in the Alsónyék cemetery. The sheath made of bent iron sheet matches the shape of Grave no. 14's iron spearhead it covered. Similar simple and undecorated sheaths associated with iron spear-

110 Klimscha et al. 2012, 353; Kozubová 2013, 95.

111 Gavranović 2011, 127-128.

112 Gavranović 2011, 128.

113 Kozubová 2013, 95.

114 Kozubová 2013, 97. 
heads often occur in Middle Iron Age graves in the Great Hungarian Plain and even further to the east, however, it is not uncommon occurrence that such iron sheets cover iron knifes in grave contexts. ${ }^{115}$ According to T. Kemenczei, most of them date to the 6th century BC, ${ }^{116}$ when they were also wide-spread in today's Oltenia and in the northern Balkans. ${ }^{117}$ Similarly, they are frequent elements in grave assemblages of the Certosa horizon in the area of today's Slovenia. ${ }^{118}$

In contrast, iron sheaths are somewhat rare items in the Iron Age material of Transdanubia, not unprecedented, though. An iron sheath covering a spearhead came to light during the excavation of the Boba tumulus ${ }^{119}$ dated to the Ha D period based on the vessel decorated with the so-called bucchero technique. ${ }^{120}$ Therefore, it is reasonable to assume that iron sheaths appeared in Transdanubia at the same time they did in the north-western Balkans, namely in the first half or in the middle of the 6th century BC as the example of Grave no. 37 at Greda M. Petrović mlađeg suggests. ${ }^{121}$

Not surprisingly, there were examples of similar objects among the finds of the Szentlörinc cemetery, however, the ones found in Grave no. 63 seem to be associated with knives instead of spears. In fact, the specimens yielded by the burials unearthed near Doroslovo ${ }^{122}$ and Vučedol ${ }^{123}$ are more comparable with the sheath from Grave no. 14 of Alsónyék in terms of both shape and function.

\section{Knives}

Short iron knives appear rather frequently in Early Iron Age grave contexts in the Carpathian Basin. ${ }^{124}$ Thus, it is hardly surprising that there are three specimens among the finds of the Alsónyék cemetery, or at least three items can surely be identified as knives (Fig. 28). In contrast to their relatively large number, their conservation is generally poor, therefore a more detailed study on their typological traits is only possible in two cases.

The knife with curved back and tang found in Grave no. 1 represents a variant that was used during the entire Early Iron Age. In Transdanubia, a similar specimen came to light among the finds of Tumulus no. 1 near Vaskeresztes,

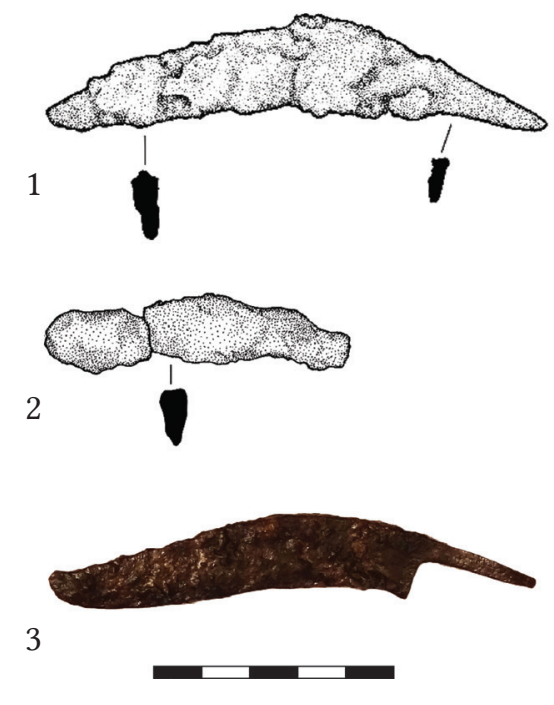

Fig. 28. Knives found in the cemetery. 1 - Grave no. 1,2 - Grave no. 14, 3 - Grave no. 16.

115 Kemenczei 2009, 38; Kozubová 2013, 101.

116 Kemenczei 2009, 39.

117 Vulpe 1967, 65; MARIĆ 1964, 36; Čović 1987a, Sl. 15,1; JAŠAREvić 2017, 16.

118 Dular 2003, T. 82,8; BožIć 2016, Pl. 1,11.

119 LÁzÁr 1955, 202.

120 Jerem 1987, 91; GÁL - MolnÁr 2004, 180.

121 Čović 1987a, 245; JAŠAREvić 2017, 17.

122 ТРАјКОВИЋ 2008, 197. Sl. 3.

123 BRUNŠMID 1902, 69.

124 Metzner-Nebelsick 2002, 409; Rebay 2006, 162; Tecco Hvala 2012, 136; Keller 2015, 57. 
a burial that can be dated to the Ha C2 period. ${ }^{125}$ Moreover, the Halimba cemetery north of the Lake Balaton yielded several similar specimens. ${ }^{126}$ An example showing considerable resemblance with the one under discussion was revealed during the excavation of the Ha D settlement near Alsópáhok. ${ }^{127}$ Furthermore, there are comparable specimens among the finds of Grave no. 14 of the Bučany graveyard ${ }^{128}$ which can be dated to the late 5th, early 4 th century BC based on the Certosa $13 \mathrm{~h}$ type fibulae found in the same context. ${ }^{129}$ Several similar examples can be found among the items discovered during the excavation of the Szentlórinc cemetery. Their chronological position is determined partly by Certosa $13 \mathrm{~h}$, partly by Certosa $13 \mathrm{c}$ type brooches. ${ }^{130}$ But there are cases where a similar knife was in context with iron crossbow fibulae comparable with the ones discovered in Grave no. 1 of the Alsónyék cemetery. ${ }^{131}$

The shape of the knife associated with Grave no. 16 differs only to small extent from that of Grave no. 1's knife. A minor dissimilarity is that in this case the point of the blade bends slightly to the back of the knife, in addition, the blade reaches its full width right next to the tang. In M. Gavranović view this shape shows resemblance with knives dated to the Urnfield Period, ${ }^{132}$ and there are similar knives among the finds of the Statzendorf, ${ }^{133}$ Fertőrákos, ${ }^{134}$ and Nagydém ${ }^{135}$ cemeteries. Moreover, the tumuli of the Sulmtal cemetery also yielded several comparable examples. ${ }^{136}$

\section{$A w l$}

The assemblage found in Grave no. 15 also included an iron object of uncertain function (Fig. 21.9). Although, during the excavation of the grave it was considered to be the fragment of a knife, after its cleaning and restoration this assumption can be firmly ruled out. The object is almost certainly an awl with the remains of its wooden helve that used to be attached to the belt of the deceased based on its relative position to the bronze belt mounts.

It is worth addressing those graves of the Szentlörinc cemetery in which the composition of grave goods is similar to that in Grave no. 15. Firstly, besides an iron spearhead and an iron belt clasp, Grave no. 6 included two short iron rods which also lay next to the pelvis of the deceased that resembles the situation in the Alsónyék case rather well. ${ }^{137}$ In addition, a similar iron rod came to light from Grave no. 12 in which the deceased was also equipped with weapons, however, in this case it was found on the ribcage of the deceased. ${ }^{138}$

It was B. Teržan who devoted an entire study to the tools in Hallstatt Age grave assemblages. She collected examples from Northern Italy to the Danube River and reached the conclusion that tools and especially tool sets are usually included in assemblages associated with the

125 Fekete 1985, Abb. 13,30.

126 Lengyel 1959, Pl. 43,7; Pl. 46,8; Pl. 48,9.

127 HoRvÁth 2015, 247.

128 Bujna - Romsauer, 1983, Taf. 2,5.

129 DizDAR 2015, 49.

130 Jerem 1968, Fig. 19,3/3; Fig 23,27/4; Fig. 23,29/6.

131 JEREM 1968, Fig. 23,29/6.

132 Gavranović 2011, 122.

133 Rebay 2006, 162.

134 Ďurkovič 2009, Fig. $24,7$.

135 Nagy 1939, Fig. 6,23.

136 Dobiat 1980, Taf. 7,1; Taf. 7,7; Taf. 22,15;

137 JEREM 1968, 161.

138 JEREM 1968, 162. 
most prominent members of the communities and thus, they might have served as status symbols in funerary contexts. ${ }^{139}$ She brings attention to awls which tend to be found among the grave goods of Late Hallstatt Age burials with weapons in the Magdalenska gora cemetery, for instance. ${ }^{140}$ It is important to note, however, that according to the author, graves equipped with tools or sets of tools can hardly ever be dated after the middle of the 6th century BC. In contrast, her collection of examples also includes a grave from Donja dolina which according to Z. Marić belongs to phase IIc, that is, to the phase of the proliferation of Certosa fibulae in the area of the Sava River's middle course. ${ }^{141}$

Incidentally, Grave no. 24 at Greda M. Petrović mlađeg bears significance not simply because of the casting mould found among the grave goods, but because similarly to Grave no. 15 in Alsónyék and Grave no. 6 in Szentlőrinc the grave assemblage also contained a belt clasp with a central bar beside two iron spearheads and a long battle knife. ${ }^{142}$

\section{Whetstones}

There are two graves (Grave no. 15 and Grave no. 16) containing whetstones among the burials of the Alsónyék cemetery hitherto excavated. Each grave assemblage contained a single whetstone. These two graves are rather dissimilar from several aspects including the composition of grave goods and the burial rite. In the case of Grave no. 16 apart from an iron knife there was no other grave good connected with the cremation burial, though, it must be emphasised that this grave had been heavily disturbed. In contrast, as earlier discussed the items found in Grave no. 15 indicate that the deceased buried into this grave might have belonged to a prominent group within the community using the graveyard. Also, it should not be ruled out that in this case the whetstone was part of the armament.

In the case of the earlier Hallstatt Age of Transdanubia whetstones appear fairly frequently in burial assemblages and similarly, they are often accompanied by weapons. Perforated specimens came to light from the Győrújbarát 1 tumulus in the north-western part of the region. ${ }^{143}$ One might argue that from certain aspects Tumulus no. 5 near Vaszar is probably the most significant mound in that cemetery. Besides iron spearheads, horse trappings, several tools and some ceramic vessels the grave goods included a whetstone. ${ }^{144}$ Whetstones were there among the grave goods of Tumulus no. 2 near Somlóvásárhely ${ }^{145}$ and Tumulus no. 1 at Pécs-Jakabhegy ${ }^{146}$ and several other burial mounds in Transdanubia, but there are instances of such tools in funerary contexts in so-called 'flat' cemeteries like the one found near Halimba. ${ }^{147}$

Contrary to the find types previously discussed, whetstones have been unprecedented as far as Late Hallstatt Age grave assemblages in southern Transdanubia are concerned. In contrast, in the case of the sites of the Vekerzug culture whetstones are frequently included among grave goods, although, there are examples of cemeteries where not a single specimen came

\footnotetext{
139 TERŽAN 1994.

140 Tecco Hvala 2012, 341.

141 MARIĆ 1964, 43.

142 TRUHELKA 1904, 94.

143 Figler 2010, 18.

144 Mithay 1980, Fig. 10,7.

145 PATEK 1993, Abb. 66,5.

146 TöRÖK 1950, Taf. 4.

147 Lengyel 1959, Pl. 38,1; Pl. 43,6.
} 
to light. ${ }^{148}$ Based on the presence or absence of perforated holes for hanging the whetstones A. Kozubová distinguishes two variants, both of which are fairly common. ${ }^{149}$

Perforated whetstones are certainly not unprecedented in contexts showing strong cultural contacts towards the Alsónyék cemetery. To begin with, according to Č. Truhelka these items are fairly common among the finds of the Donja dolina cemetery, however, there are only two examples found in well-documented contexts. ${ }^{150}$ It is worth mentioning however that one of the latter is Grave no. 34 at Greda N. Sokić ${ }^{151}$ which contained a spear with sheath, two further spearheads and a machaira type battle knife. However, it is worth emphasising that this grave is possibly somewhat older than the burials of the Alsónyék cemetery considering the fact that the machaira found in the grave assemblage can be dated to the 6th century BC. ${ }^{152}$ In spite of this, however, it is worth paying more attention to the Late Hallstatt Age graves in today's Bosnia, especially as the best analogies of the belt clasp found in Grave no. 15 of the Alsónyék cemetery are known, as discussed earlier, from these regions.

14 perforated whetstones are known from the Sanski most cemetery, found during the 19th century excavations of the site. Among the graves containing such tools Grave no. 4 is noteworthy, considering that the burial assemblage included among other items a large spearhead and a belt clasp with a central bar. ${ }^{153}$ Based on these objects, the burial can presumably be dated to Phase $3 \mathrm{a}-2$ or $3 \mathrm{~b}$ according to the system of B. Čovićn ${ }^{154}$. Whetstones, however, appear in older contexts as well, as suggested by Grave no. $2 .{ }^{155}$ Besides Grave no. 4, Grave no. 60 also supports the assumption that whetstones were standard elements of the warrior equipment, ${ }^{156}$ however, there are several cases where the grave assemblages containing whetstones lacked weapons. This is the situation with Grave no. 16 in the Alsónyék cemetery.

Čarakovo is the third site in today's north-western Bosnia and Herzegovina which is worth mentioning. The cemetery found here was dated by B. Čović to his $3^{\text {rd }}$ period. ${ }^{157}$ Among the graves excavated at this site, three burials were equipped with weapons and two of them contained perforated whetstones. ${ }^{158}$ As far as their shape can be assessed based on the available drawings, these whetstones are the best analogues to the piece found in Grave no. 15 of the Alsónyék cemetery. In both cases the whetstones were associated with spearheads, and the grave assemblage of Grave no. 4 of the Čarakovo graveyard included an iron belt buckle ${ }^{159}$ fairly similar to the specimens found in the Szentlőrinc cemetery. ${ }^{160}$

So far, graves with weapons are seemingly rare among the burials of the so-called South Pannonian Late Hallstatt group, thus this might partly explain why whetstones in general are also rare in the archaeological material. There is nevertheless a noteworthy example. Among

148 Kemenczei 2009, 187; Kozubová 2013, 121.

149 Kozubová 2013, 122.

150 TruHelKa 1904, 65.

151 Truhelka 1904, Taf. 63,8.

152 Čović 1987a, 246; 250-251; GASPARI - MLinAR 2005, 175.

153 Fiala 1899, 67.

154 Čović 1987a, 257-265.

155 Fiala 1899, 65; Čović 1987, 257.

156 Fiala 1899, 81.

157 Čović 1987a, 254.

158 Čović 1956, Tab. 1,3; Tab. 2,9.

159 Čović 1956, 189.

160 Jerem 1968, Fig. 23,28/4; Fig. 24,31/2; Fig. 29,67/9. 
the stray finds of the Iron Age graveyard in Šabac there was a perforated whetstone similar to the pieces discussed above. ${ }^{161}$ In M. Vasiljević view a Certosa fibula of Type V and other items found at the site could indicate the existence of a 5th century cemetery. Although the exact context of the whetstone remains unknown, it is worth noting that there also were several iron spearheads among the stray finds.

To sum up, it seems reasonable to conclude that in the north-western Balkans whetstones were common elements of the warriors' equipment during the 6th and 5th centuries BC. ${ }^{162}$ As a result, in spite of their apparent rarity, it is hardly surprising to see such a tool associated with a grave assemblage including characteristic items such as iron spearheads or belt clasps with a central bar. In addition, though, there are numerous examples where whetstones are parts of grave assemblages completely lacking weapons, especially in the eastern part of the Carpathian Basin.

\section{Beads}

\section{Glass paste beads}

Both in terms of their amount and the number of graves containing them, glass paste beads represent the most abundant type of grave goods in the case of the Alsónyék cemetery (Tab. 1). Basically, two variants can be distinguished, however, the occurrence of beads decorated with eye motifs and simple unicolour beads does not show any differences. Since most of the beads were found around the neck or on the upper part of the body it is reasonable to conclude that the beads formed necklaces. ${ }^{163}$

Tab. 1. Summary of the glass paste beads of the Alsónyék cemetery

\begin{tabular}{|c|c|c|c|c|c|}
\hline & \multirow{2}{*}{ Unicolour } & \multicolumn{3}{|c|}{ Beads with eye motifs } & \multirow{2}{*}{$\Sigma$} \\
\hline & & In one row & In two rows & Twin beads & \\
\hline Yellow & $\begin{array}{l}\text { Grave no. } 12(10) ; \\
\text { Grave no. } 9(3) ; \\
\text { Grave no. } 8(43) ; \\
\text { Grave no. } 9(4) ; \\
\text { Grave no. } 6(8) ; \\
\text { Grave no. } 2(4) ; \\
\text { Grave no. } 1(14)\end{array}$ & $\begin{array}{l}\text { Grave no. } 8(22) ; \\
\text { Grave no. } 6(1) ; \\
\text { Grave no. } 2(1)\end{array}$ & $\begin{array}{l}\text { Grave no. } 8(5) \text {; } \\
\text { Grave no. } 2(1)\end{array}$ & Grave no. 8 (2) & 118 \\
\hline Dark blue & $\begin{array}{l}\text { Gr. } 8 \text { (28); Gr. } 6 \text { (1); } \\
\text { Gr. } 2 \text { (23); Gr. } 1 \text { (8) }\end{array}$ & - & - & - & 60 \\
\hline Turquoise & $\begin{array}{l}\text { Gr. } 12(6) \text {; Gr. } 6(4) \text {; } \\
\text { Gr. } 1 \text { (8) }\end{array}$ & Gr. 8 (2); Gr. 2 (1) & Gr. 8 (2) & - & 23 \\
\hline Brown & Gr. 12 (1); Gr. 1 (2) & - & - & - & 3 \\
\hline White & $\begin{array}{l}\text { Gr. } 10 \text { (1); Gr. } 2(15) \text {; } \\
\text { Gr. } 1 \text { (7) }\end{array}$ & - & - & - & 23 \\
\hline$\Sigma$ & 190 & 27 & 8 & 2 & \\
\hline
\end{tabular}

161 ВАСИљЕВИЋ 1976, Сл. 5,4

162 Bakarić et al. 2006, 115; Tecco Hvala 2012, 341; Čović 1987a, 257.

163 HORNÁK 2006, 38. 
Interestingly, Grave no. 8 contained almost as many beads (115 pieces) as the rest of the graves combined (Fig. 13). This number is comparable with the amount of beads found in Grave no. 58 near Tolna-Mözs or in the Paks-Gyapa grave. ${ }^{164}$ In spite of the obvious disturbance affecting mainly the upper part of the skeleton, only relatively few beads were scattered farther from the neck and chest of the deceased. It is worth noting, that even though Grave no. 8 yielded the largest amount of beads in the cemetery, this number is only a fraction of that of the beads in Grave no. 1 of the Beremend cemetery. ${ }^{165}$ Contrary to the situation in the case of Grave no. 8 , however, the beads of the Beremend grave were reportedly found around the cranium and arranged like the ornaments of some kind of headdress. ${ }^{166}$

Glass paste beads appeared in Transdanubia at the end of the Urnfield period and their presence throughout the Early Hallstatt Age is well-documented, although, they are fairly rare. ${ }^{167}$ Their proliferation in the southern part of named region can be dated to the Ha D2/3 periods. ${ }^{168}$ On the one hand, glass paste beads came to light in relatively large quantities from the graves found near Beremend, Szárazd and Paks, on the other hand there are numerous examples of such beads among the finds of the Szentlörinc cemetery but their average number per grave is considerably less (Fig. 29).

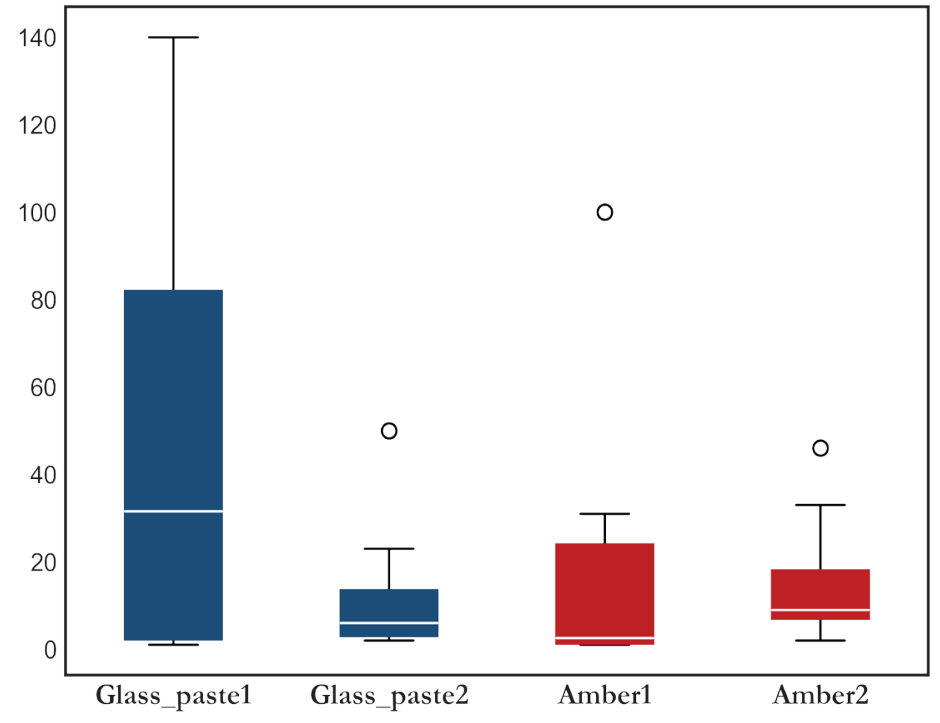

Fig. 29. Bloxplot diagram of the amount beads found in the solitary graves (1) and (2) the graves of the Szentlörinc cemetery, respectively.

Interestingly, so far glass paste beads only came to light from the northeaster part of the hitherto excavated section of the Alsónyék cemetery. This means that in contrast for instance to the Sopron-Krautacker graveyard, ${ }^{169}$ such elements of attire did not appear in graves including weapons.

\section{Beads with eye motifs}

Beads with eye motifs are one of the most characteristic and most recognisable elements among Late Hallstatt Age grave goods in southern Transdanubia, however, it must be borne in mind that the great majority of such beads came to light in the eastern part of the Carpathian Basin, especially from the Szentes-Vekerzug cemetery and graveyards along the middle course of the Tisza River. ${ }^{170}$ Due to the fact that glass paste beads with eye motifs appear most abundantly in Slovenia in the time period under consideration, and literature even mentions a so-called 
"Schichtaugenperlenhorizont" in that region parallel to the period of the late serpentine, Certosa and animal-headed fibulae, ${ }^{171}$ some argue that their proliferation in the Carpathian Basin is an evidence for the strong communicational ties maintained between the two regions. ${ }^{172}$ In fact, in the case of the Donja dolina cemetery the strong relationship between Certosa fibulae and the beads with eyes motifs is quite apparent. ${ }^{173}$

One possible way of classifying beads with eye motifs is based on their base colour. According to this approach two types of such beads can be distinguished in the case of the Alsónyék cemetery. On the one hand, there are turquoise beads which are less abundant, as well as beads of yellow base colour. Apart from a single piece, all turquoise beads with eye motifs came to light from Grave no. 8, but they are strongly outnumbered by those with yellow base colour. Grave no. 2 yielded one bead of each type, Grave no. 6 yielded only a single yellow bead with eye motifs. In general, in the Great Hungarian Plain yellow beads with eye motifs are more common than those with turquoise base colour, moreover, this seem to apply to the entire distribution area of the beads with eye motifs. ${ }^{174}$ Interestingly, the great majority of glass paste beads in Grave no. 1 in Beremend were of turquoise colour and there were no yellow beads with eye motifs among the grave goods. ${ }^{175}$

Another approach to the classification applies to the different patterns in the eye motifs' arrangement. This approach, similarly to the method mentioned above, also leads to the distinction of two types. The eye motifs are arranged into two rows on 6 beads of Grave no. 8 and on one bead of Grave no. 2. Several similar beads came to light during the excavation of the Szentlórinc cemetery and there are comparable examples among the finds of both the Szárazd-Gerenyáspuszta burial and the Beremend graves. ${ }^{176}$ Interestingly, all turquoise beads with eye motifs belong to this category. In addition, in the Iron Age material found in the territory of today's Hungary, beads of this type are considerably more numerous than those beads whose eye motifs are arranged into a single row. In contrast, the situation in the area of today's Slovenia is just the opposite. ${ }^{177}$

Among the beads of Grave no. 8 there are two rather peculiar examples (Fig. 13.14). These double beads with eye motifs are certainly not unprecedented. K. Kunter managed to collect more than 120 specimens in his monograph. ${ }^{178} \mathrm{In}$ his view, this type of double beads prove that beads with eye motifs were in a certain way 'mass-produced'. This might raise the question whether such beads were manufactured locally, however, at this point, it is not possible to answer this question.

\section{Unicolour glass paste beads}

Most of the unicolour glass paste beads have a simple globular shape, their diameter varies between 0.5 and $1.0 \mathrm{~cm}$. Based on their colour, four main types can be distinguished. The great majority of the beads is either of yellow or blue colour. The number of turquoise and white beads is

171 KunTER 1995, 36.

172 JEREM 1981, 210-212.

173 Čović 1987a, 258; Kunter 1995, 37.

174 Kemenczei 2009, 88; Kunter 1995, Abb. 19.

175 JEREM 1973, 68.

176 PATEK 1982, 178-179.

177 Kunter 1995, Abb. 20.

178 Kunter 1995, 240. 
considerably smaller. Even though unicolour beads are common elements of Late Hallstatt Age burial assemblages, there are specimens which deserve special attention owing chiefly to their shape. For instance, two pieces among the beads of Grave no. 6 have ellipsoidal shape and they are decorated with longitudinally running ribs (Fig. 9.3). The Late Hallstatt Age archaeological material in Transdanubia lacks further examples of this variant, however, identical beads came to light from Grave no. 1 near Vučedol. ${ }^{179}$ Similarly, the prism-shaped bead from Grave no. 11 currently stands alone among the Late Hallstatt Age finds in Transdanubia (Fig. 16.A.1).

\section{Amber beads}

Considering the fact that in prehistoric archaeology amber is generally perceived as a prestigious material, it is not surprising that in terms of grave goods the richest graves of the cemetery contained amber beads, however, they did not appear among the finds of burials with weapons. Special attention should be paid to the bead found in Grave no. 8 for its oblique funnelled decoration (Fig. 13.12).

The Amber Road was one of the most important trade routes in Early Iron Age Europe. ${ }^{180}$ One branch of this route certainly ran along the eastern Alpine foothills. From the 8th century BC onwards, the amount of amber in the area of today's Slovenia increased significantly. It is most likely, that the aforementioned trade route played an essential role in this process, and thus it is hardly surprising that items made of amber appeared in the Early Iron Age burial assemblages in Transdanubia. The fundamental transformations of the first half of the 6th century $\mathrm{BC}$ certainly affected the local elites and the communicational networks they maintained. As a result, the significance of the western routes in the amber trade grew while that of the eastern routes sank, but these latter certainly never ceased to exist. ${ }^{181}$ In fact, from the end of the 6th century $\mathrm{BC}$ onwards the communication between the northern and southern regions in the foreground of the Alps became dynamic again. ${ }^{182}$ Arguably, this might explain the relatively large amount of amber items in graves of the Dolenjska group during the so-called Certosa horizon. ${ }^{183}$ At the same time, nonetheless, the significance of another communication route increased rapidly. This route, probably having two branches along the Drava and Sava rivers, and crossing the Danube-Tisza Interfluve, reached the area of the Great Hungarian Plain. ${ }^{184}$

One possible set of evidence for the existence of this communication route, as P. Kmetová recently convincingly showed, are the horse burials ${ }^{185}$ while the distribution of amber items appearing in relatively large numbers in the Srem, Bačka, and Baranya regions suggests the same. ${ }^{186}$

It is worth to note that only those graves contained amber beads which also yielded necklaces made of glass paste beads. Hence, it is more than likely that the amber beads were included among the beads comprising the necklaces, although, firm conclusions cannot be drawn due to the disturbances documented within the graves.

179 BRUNŠMID 1902, Sl. 25.

180 CHYTRÁČEK et al. 2017, 188.

181 CHYTRÁČEK et al. 2017, 194-195.

182 JerEm 1981, 212; CHytráčEK et al. 2017, 196.

183 Tecco Hvala 2012, Sl. 106.

184 CHYTRÁČEK et al. 2017, 196.

185 KMEŤOvÁ 2017, 109-110.

186 VAsić 1989, 104; Sremska Mitrovica (Brunšmid 1902, 75); Doroslovo (БрукнЕР 1959, 7); Šabac (ВАсиљЕвИћ 1976, 170). 


\section{Spindle whorl}

There are two graves among the hitherto excavated ones at Alsónyék which yielded spindle whorls, one piece in each grave. In the case of Grave no. 1 the item made of clay was found next to the hipbone of the deceased (Fig. 3.7). The undecorated doughnut-shaped whorl in Grave 8 no. lay near right knee (Fig. 12.11). Despite its rather poor condition it is quite beyond doubt that the specimen found in Grave no. 1 bears oblique channelled decoration which makes it similar to the specimen found in Grave no. 2 of the Beremend cemetery. ${ }^{187}$

Although there are critical views regarding the issue, ${ }^{188}$ spindle whorls are generally considered as one of the main attributes of female graves in the Eastern Hallstatt Zone. ${ }^{189}$ This assumption is supported by the Magdalenska gora, Szentlörinc and Strubarlija cemeteries, just to name a few examples. ${ }^{190}$ Unambiguous counterexamples are certainly missing from the hitherto excavated part of the Alsónyék cemetery, however, in the case of the Vekerzug culture, spindle whorls also appear in graves considered to be male burials. ${ }^{191}$

\section{Pottery}

Based on the find assemblages of hitherto unearthed graves at Alsónyék, pottery is a rather rare element among grave goods. However, as far as the Late Hallstatt Age graveyards in southern Transdanubia, eastern Slavonia and northern Serbia are concerned, this seems to be a general phenomenon which is in drastic contrast to the funerary customs observed in the earlier phases of the Early Iron Age. ${ }^{192}$ At Alsónyék, there are only five graves containing ceramic vessels, ${ }^{193}$ each of them yielding only a single pottery (Fig. 30). It is worth mentioning that in some cases there were a few sherds in the graves, but neither is it possible to typologically analyse nor to date these. It is rather questionable whether their presence within the graves is intentional or accidental, but it is worth noting that similar phenomena are recorded in the case of both the Szentlörinc and Szeged-Kiskundorozsma cemeteries. ${ }^{194}$

From a technological point of view it is important to highlight that all vessels are handmade. In contrast to the elements of the vessels sets in Early Hallstatt graves, these potteries are rather small. The only arguable exception is the urn from Grave no. 16, however, due to its missing fragments its exact dimensions are hardly discernible.

\section{Kantharoi}

Although ceramic vessels are on average rare in Late Hallstatt Age burial contexts in southern Transdanubia, there is certainly a truly characteristic vessel type among them, the so-called kantharos. Kantharoi are also known from settlement contexts in the region between the Lake Balaton and the Sava River. The recently excavated Szajk settlement yielded several examples of this type ${ }^{195}$ and one specimen appeared among the finds of the most recent phase of the

187 Jerem 1973, Abb. 6,2.

188 PRimas 2007, 307.

189 TeržAn 1984, 228; Rebay 2006, 112; Rebay-SAlisbury 2016, 81.

190 Tecco Hvala 2012, 342; Jerem 1968, 187; Medović 2007, 10.

191 KeMENCZEI 2009, 93.

192 MetZner-Nebelsick 2002, 177.

193 Grave no. 2, Grave no. 6, Grave no. 9, Grave no. 15, Grave no. 16.

194 Jerem 1968, Fig. 23,28/7; Fig. 25,40/8; Fig. 26,46/3; Fig. 29,63/2; Fig. 29,67/10-11; Pilling - UjváRi 2012, Fig. 4.

195 GÁTI 2014, 117. 
multi-layered settlement of Gradina na Bosut, ${ }^{196}$ also pieces belonging to this type were found at several north-eastern Serbian sites. ${ }^{197}$

So far two kantharoi came to light from the Alsónyék cemetery (Grave no. 6 and Grave no. 15). The vessels in both cases were placed next to the feet of the deceased. This is a recurring custom in the Szentlorinc cemetery, however, vessels situated next to the head of the deceased are not unprecedented either. ${ }^{198}$ In contrast, in the case of the Vinkovci-Nama cemetery ceramic vessels were in all cases next to the head of the deceased. ${ }^{199}$ The situation observed in the case of the Stubarlija cemetery, however, resembles the Alsónyék cemetery quite well. Here, save a single exception, all vessels stood next the feet of the deceased, moreover, most of the vessels were in fact kantharoi. ${ }^{200}$

According to the general perception, the main production area of kantharoi is the region between the Kapos and Sava Rivers. ${ }^{201}$ This is why the 5th century BC specimens found in Lower Austria are referred to as imports. Their appearance can be dated to the end of the 6th century and to the beginning of the 5th century BC. ${ }^{202}$ It is worth pointing out though that their distribution area is not limited to the areas lying north of the Sava River. The vessel found in one of the graves of the Donja dolina cemetery is certainly an evidence for this, ${ }^{203}$ but the example of the two specimens found in Grave no. 1 in Arareva gomila, one of the most famous princely burials in the Glasinac area, ${ }^{204}$ is probably even more significant. Given the Korinthian helmet found among the finds this kantharos can most likely be dated to the second

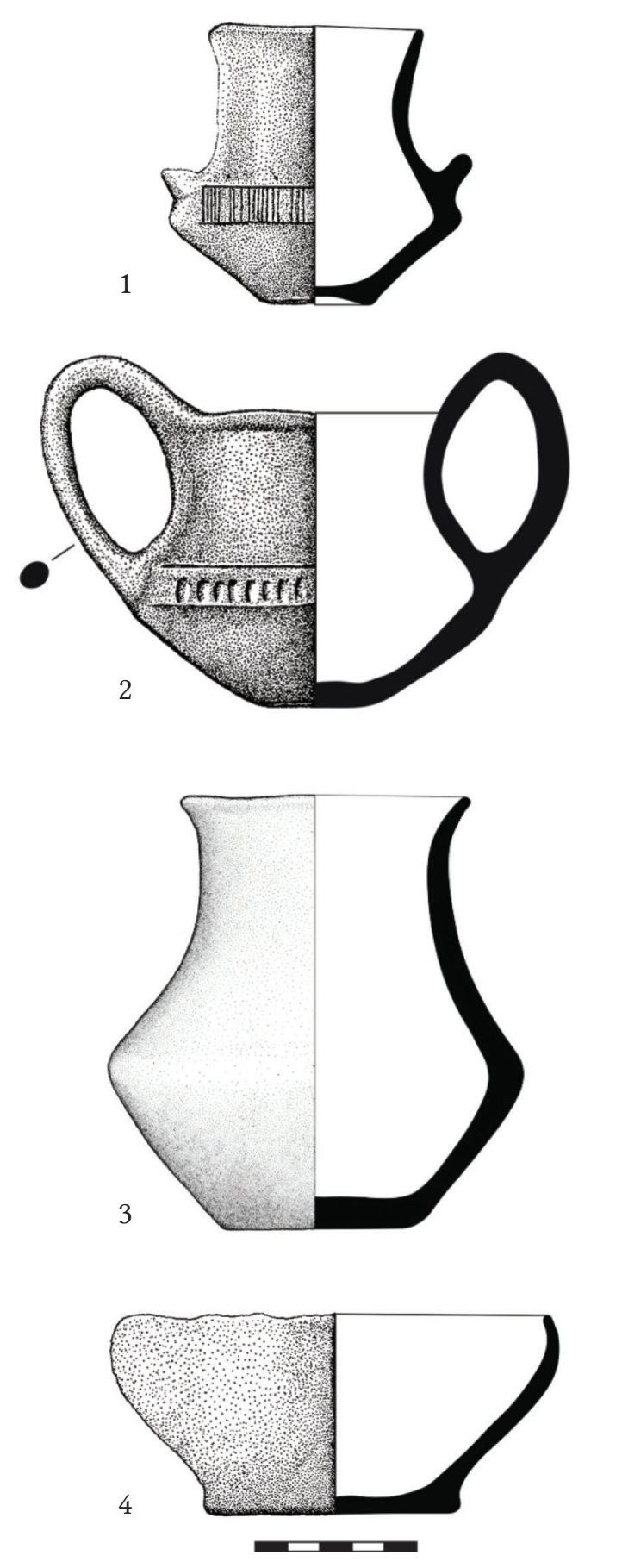

Fig. 30. Ceramic vessels found in the cemetery. 1 - Grave no. 6, 2 - Grave no. 15, 3 - Grave no. 2, 4 - Grave no. 9.

196 Medović - Medović 2011, Sl. 244,2.

197 KAPURAN 2013, 30.

198 JEREM 1968, 188.

199 MAJNARIĆ-PANDŽIć 2003, 484-488.

200 Medović 2007, 16; 19.

201 Jerem 1996, 103; Dizdar 2010, 299.

202 Jerem 1996, 107; Dizdar 2010, 299.

203 Truhelka 1904, Taf. 43,2.

204 BenAC - Čović 1957, Tab. 40,2.3. 
half of the 6th century BC. ${ }^{205}$ Interestingly, besides Grave no. 15 at Alsónyék, so far this is the only burial the grave goods of which included both weapons and kantharoi.

\section{Bowl with inverted rim}

The vessel in Grave no. 9 stood to the right of the deceased (Fig. 14.A.2). Curiously, so far similar vessels are missing from the finds collected at those sites between the Kapos and Sava Rivers where Certosa fibulae of Type V occurred. In contrast, the Szentlörinc cemetery yielded two comparable vessels with conical shape and inverted rim. ${ }^{206}$ A fairly good analogy of the bowl under discussion came to light from the Vinkovci-Nama cemetery, which was partly synchronous with the graveyard unearthed near Szentlörinc. ${ }^{207}$ Similar vessels appear abundantly among the finds unearthed at the sites of the Alföld group which is hardly surprising considering that bowls with inverted rim represent one of the most common vessel types. Hence, numerous examples are known for instance from the Tápiószele ${ }^{208}$ and Szentes-Vekerzug cemeteries. ${ }^{209}$

\section{Small biconical vessel}

The small pot in Grave no. 2, similarly to the kantharoi, was found next to the feet of the deceased (Fig. 5.1). Interestingly, the most noticeable difference between the shape of this vessel and that of the kantharoi (especially the piece from Grave no. 6) is the lack of handles. Neither the Szentlörinc nor the Beremend cemetery yielded comparable vessels. The best analogy of the pot was found in Grave no. 14 of the Vinkovci-Nama cemetery. ${ }^{210}$

\section{Urn from Grave no. 16}

During the removal of the humus layer, the excavator heavily disturbed Grave no. 16. The urn containing the human remains was also damaged in the process, apparently its fragments are lost. Consequently, a detailed typological evaluation is not possible at the moment. ${ }^{21}$

\section{The layout of the cemetery and its environment}

Alsónyék-Hosszú dülő is located in the southeastern part of Transdanubia, that is, Western Hungary, quite close to the Danube River. Based on the maps of the First military survey of the Habsburg Empire, the Middle Iron Age cemetery was located between the right banks of the Sárvíz River prior to the river regulations in the 19th century and the Szekszárd hills, respectively. Hence, this location is bordered by an area characterised by creeks and a vast marshland formed by the Sárvíz and Danube Rivers on the one hand, and hills on the other (Fig. 31). ${ }^{212}$ Whereas the areas frequently flooded have an altitude of $86-87 \mathrm{~m}$ above the mean sea level, there are island-like, 6-7 m higher elevations which were permanently dry. ${ }^{213}$ The

205 Pflug 1988, 104; Васић 2009, 110; Gavranović 2011, 202.

206 Jerem 1968, Fig. 21,19/2; Fig. 22,26/1.

207 MAJNARIĆ-PANDŽIć 2003, Abb. 7,2.

208 PÁrducz 1966, Taf. 21,14; Taf. 25,13; Taf. 31,2.5; Taf. 35,10; Taf. 36,14; Taf. 45,10.

209 PÁrducz 1955, Taf. 14,4.

210 Majnarić-PANDŽić 2003, Abb 6,1.

211 It has to be pointed out that one cannot rule out the possibility that the picture presented on Fig. 22 should be considered upside-down.

212 OszTÁs et al. 2013, 8-9.

213 Balázs Kovács 2015, 217. 
cemetery is located on the first alluvial terrace, thus the annual floods did not reach it. This situation resembles the picture of the natural environment of the Beremend and SzárazdGerenyáspuszta sites.

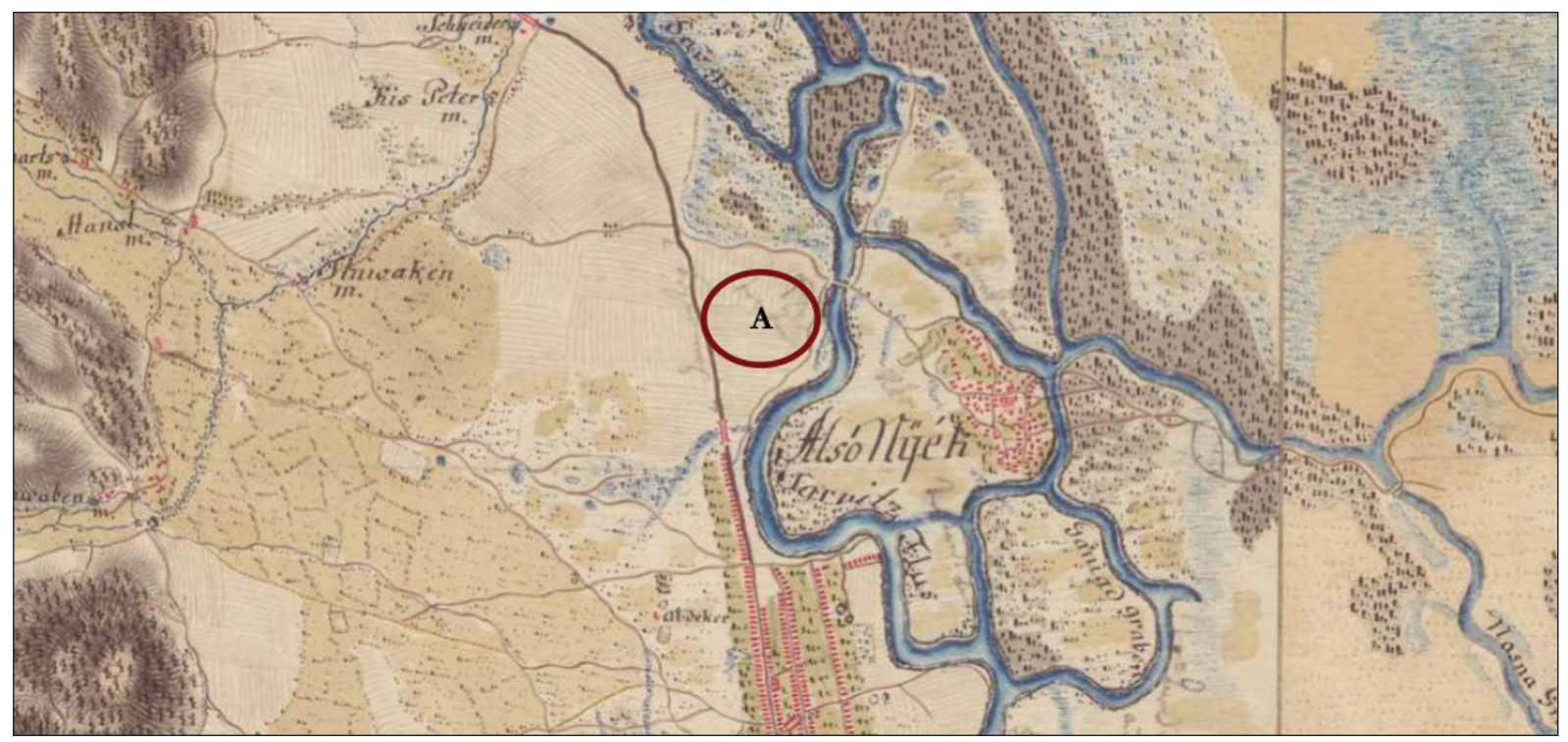

Fig. 31. Map section of the Josephinian Land Survey showing the environs of the site. Source: https:// mapire.eu/hu/map/firstsurvey-hungary (last access: 01.11.2020).

Although the entire extent of the cemetery is currently unknown, the layout and relative positions of the graves hitherto excavated are worth discussing. By looking at the map of the excavated area one can distinguish two grave groups. On the one hand there are relatively densely situated graves in the north-eastern section of the excavated area. On the other hand, there are sporadically situated burials to the southwest. In addition, it is noticeable that all graves with astragal belts were located in the north-eastern section, on the other hand, both spearheads came to light from graves located in the southwestern part of the excavated area (Fig. 32). Interestingly, the mean of the distances measured between each grave and its nearest neighbour is $9.47 \mathrm{~m}$, which is considerably larger than the value measured in the case of the Szentlörinc cemetery. Although it must be borne in mind that while the Alsónyék cemetery is not entirely explored, the one excavated in Szentlörinc arguably is. The above values indicate that these cemeteries might have different structural properties, though, there are also similarities, nonetheless.

For instance, both cemeteries show features indicating that, according to M. Parker Pearson's classification, they can be assigned to those of segmented organization. ${ }^{214}$ This, however, is more readily visible in the case of the Szeged-Kiskundorozsma (Fig. 33) and Novi Sad graveyards ${ }^{215}$ which are certainly comparable to the Szentlörinc cemetery from various aspects, including chronological span, burial customs and material culture. The former is an excellent example because the layout of the two distinct grave groups shows similarities with those of the Alsónyék cemetery and Szentlőrinc graveyard, respectively. While in the case of the western group the average distance between the nearest neighbours is approximately $1.6 \mathrm{~m}$, this value is $13.5 \mathrm{~m}$ when the graves of the eastern group are concerned. 


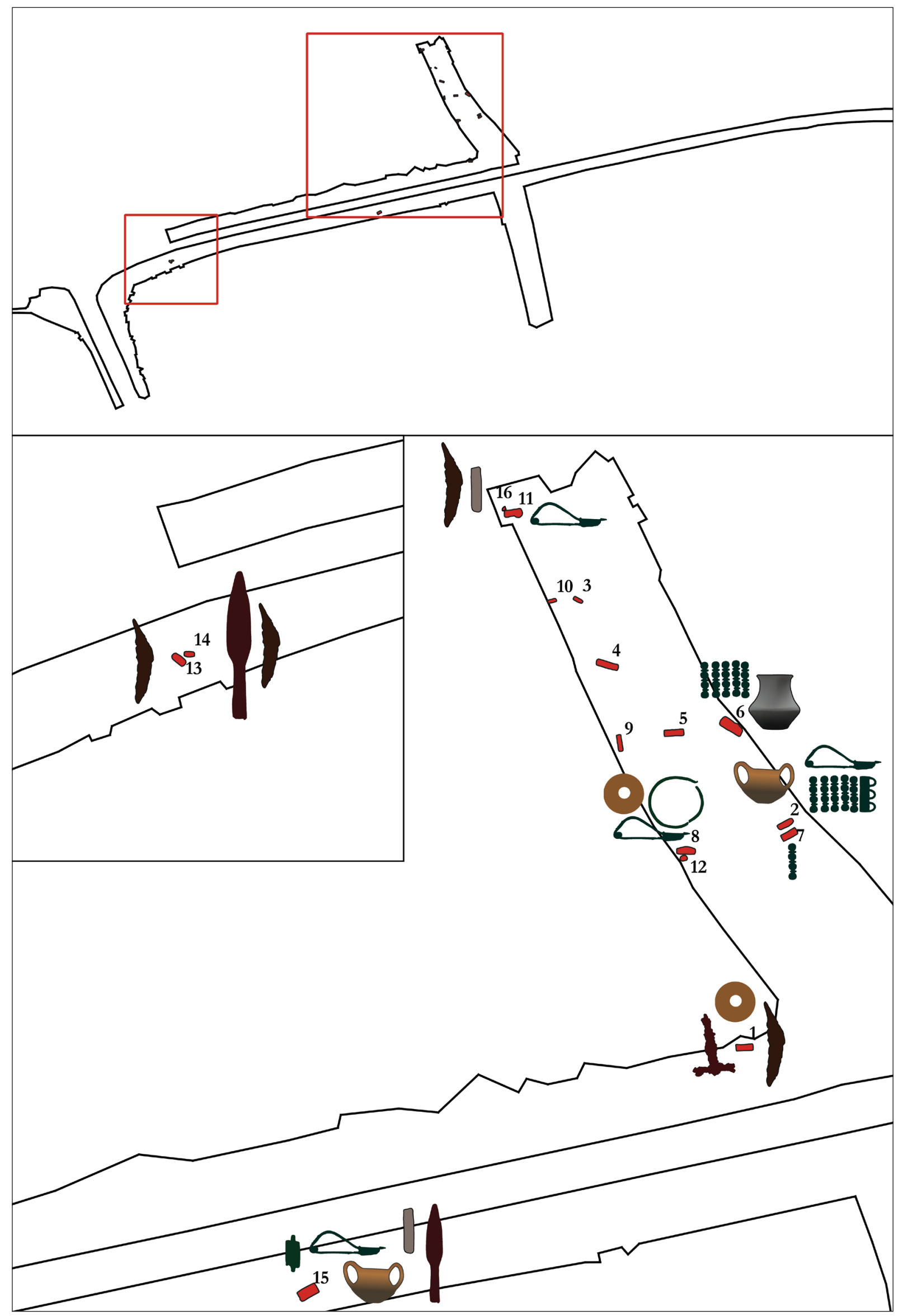

Fig. 32. Distribution of the characteristic types in the cemetery. 


\section{Burial customs}

\section{Burial rite}

The excavated graves included 13 inhumations and 2 cremation burials. In Grave no. 7 no human remains were found. Based on the graves found near Sopron-Krautacker, Kapuvár and Beremend, Erzsébet Jerem convincingly showed how inhumation had become the predominant way of burying people with the proliferation of the Certosa fibulae in the western parts of the Carpathian Basin. ${ }^{216}$ Hence, it is not surprising that the majority of the burials in the Alsónyék cemetery are inhumations. It is important, however, that the cemetery shows a certain diversity in burial rites which is not unprecedented in southern Transdanubia and in the regions to the southeast, but it is certainly not a common phenomenon, nevertheless. In fact, there is only a single case showing similar diversity in named regions. Among the burials in the Szentlörinc cemetery the predominance of inhumation is clearly visible, but there are also burials with cremated human remains scattered in the grave pits, although their number is considerably smaller. There is also a third category. During the excavation a few grave pits were identified which did not contain any human remains. Hence, E. Jerem perceived them as symbolic burials.

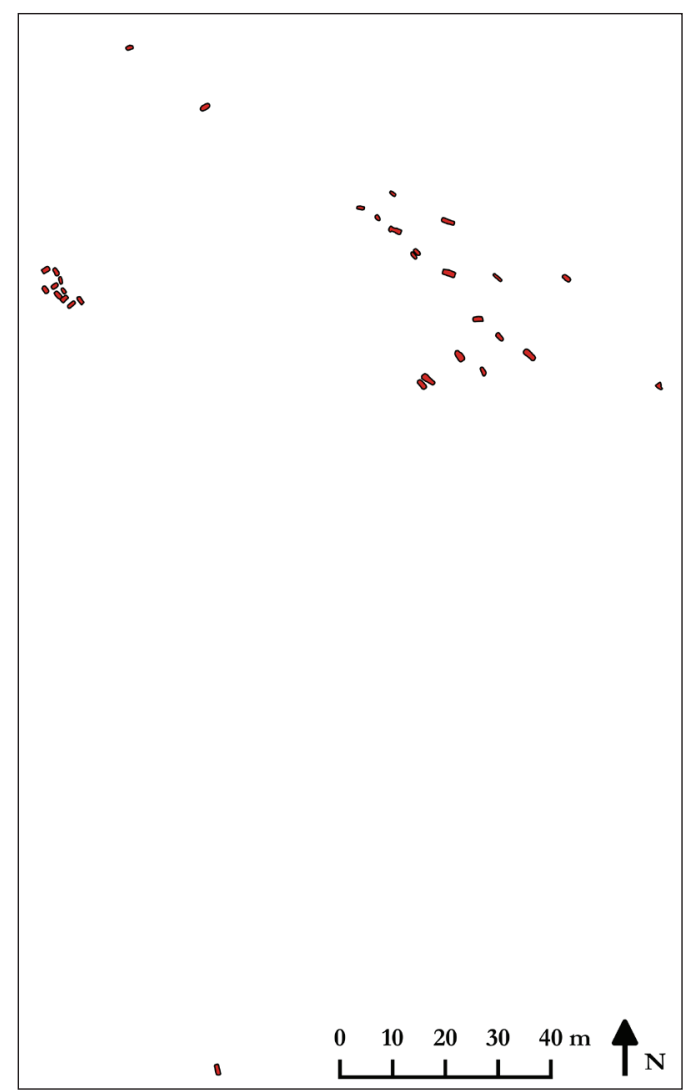

Fig. 33. Map of the Szeged-Kiskundorozsma cemetery. Interestingly, Grave no. 7 in the Alsónyék cemetery did not contain any human remains, however, it is not easy to decide whether it can be considered a symbolic burial. At least two other scenarios have to be taken into account. On the one hand, the lack of human remains can very well be the result of secondary manipulation or grave robbery. There are several examples of such manipulations in contemporaneous cemeteries, but this issue shall be touched upon somewhat later. On the other hand, given the slight relative depth of the graves, it cannot be ruled out that the human remains were removed during the removal of the humus layer.

Although both cemeteries yielded cremation burials, this is not a clear-cut similarity between the two because there were no urn graves in the Szentlőrinc cemetery. The Alsónyék cemetery, however, provided examples for both types of cremation burials.

\section{Position of the human remains}

In the case of the inhumation burials, the majority of the deceased were laid into the grave in a supine position. However, there are minor differences. For instance, in Grave no. 15 the deceased lay turning slightly to the right, in addition, both hands were placed next to the head (Fig. 20). As far as well-documented burials are concerned, this way of positioning the deceased 
is unprecedented in the Late Hallstatt Age in southern Transdanubia. Unfortunately, in the case of the large cemeteries in north-western Bosnia and Herzegovina the exact position of the deceased is poorly documented, thus comparable examples cannot be found there, either.

In the other cases, whenever it was possible to detect such details, the arms had been bent so that the hands were placed onto the ribcage. According to the observation of P. Medovic this was a recurring element in the Stubarlija cemetery ${ }^{217}$ and the same phenomenon was documented in the Tolna-Mözs grave, ${ }^{218}$ both dated to the 5th century BC. ${ }^{219}$ There are also examples from the 4th century BC. The same pattern appears in the case of the Szeged-Kiskundorozsma $^{220}$ and the Novi Sad ${ }^{221}$ graveyards and in the case of the Šid-Beljnjača burial. ${ }^{22}$ It is worth mentioning that graves where the hands of the deceased lay in the pelvis area are certainly not unprecedented either. ${ }^{223}$ It cannot be ruled out that such instances might have existed among the excavated burials, however, their detection was made impossible by the disturbances and secondary manipulations.

Disturbance may also hinder the determination of the orientation of the bodies. Based on the relatively undisturbed examples, the $\mathrm{W}-\mathrm{E}$ axis with minor inclinations either to north or south seems predominant. There is only one truly obvious counterexample. The body of the infant in Grave no. 9 was oriented towards north (Fig. 14.A).

It is worth drawing attention to the fact that E. Jerem has already highlighted the W-E axis predominance in the Late Hallstatt Age, based on major graveyards in the north-western Balkans and the Szentes-Vekerzug cemetery. The unearthed section of the Alsónyék cemetery is certainly not an exception to the pattern (Fig. 34). Neither is the largest Late Hallstatt Age cemetery in southern Transdanubia. ${ }^{224}$ It is important to note that while in the case of the Szentlörinc cemetery orientation to the west is predominant, older Late Hallstatt Age burials in Trandanubia (e.g. the Beremend graves) show a certain balance between numbers of graves oriented towards east and west. Interestingly, with only one exception, all graves of the recently unearthed cemetery near Novi Sad were oriented towards west. Naturally, exceptions ${ }^{225}$ are omnipresent, though not in great numbers. ${ }^{226}$

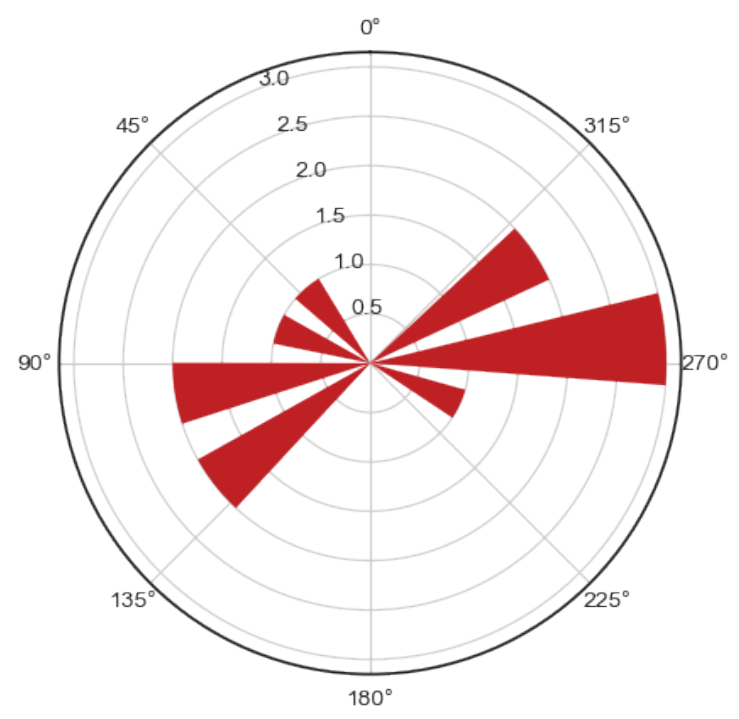

Fig. 34. Orientation of the graves at Alsónyék.

217 Medović 2007, 87.

218 GAÁL 2001, Pl. 10.

219 DizDAR 2015, 53.

220 Pilling - Ujvári 2012, 229.

221 АНЂЕЛИЋ 2017, Pl. 10-12.

222 КОЛЕДИН 2012, Sl. 1.

223 Jerem 1968, Fig. 7; АНъЕлић 2017, Т. 12.

224 JEREM 1968, 174-175.

225 One notable example is the grave found near Szárazd-Gerenyáspuszta the longitudinal axis of which was reportedly aligned to the N-S axis. Source: Nándor Fettich's report (Hungarian National Museum, Archives. Call no. 35.Gy.1)

226 КОлЕДИН 2012, Sl. 1; Medović 2007. 


\section{Structural features of the graves}

Based on the graves hitherto excavated at Alsónyék, rectangular grave pits with rounded corners seem to be predominant. Nonetheless, there is some variability. For instance, while Grave no. 12 had an almost ovoid shape, Grave no. 1 and Grave no. 7 among others had nearly orthogonal corners. Similarly to the situation in the case of the Szeged-Kiskundorozsma and Novi Sad cemeteries the latter shape is more common. ${ }^{227}$ Unfortunately, no such observations were made or have not been published yet, at sites more closely located to the Alsónyék cemetery.

One of the most interesting features of the cemetery are the holes found in 7 out of the 16 graves. In each of these 7 graves there were either one or two holes of a diameter varying usually between 20 and $40 \mathrm{~cm}$ along the longitudinal axis. It is worth emphasising that, due mainly to the undocumented discovery of most burials, such features have not yet been observed in any Late Hallstatt Age graves in the southern part of the Carpathian Basin, though, it cannot be ruled out that the graves found near Beremend or Szárazd did not have such holes deepened into the bottom of the grave pits. Unfortunately, such observations are also missing in the case of the cemeteries in today's northern Bosnia and Herzegovina.

The function of these features are rather perplexing. In 5 out of 7 cases the grave had two holes. Grave no. 2 probably also had two but the grave pit has cut an older feature which might have hindered the observation of the second posthole (Fig. 4). It is important to note that at least in two cases the skeleton as well as the grave goods lay above these holes, hence it is conceivable that by the time the deceased was laid into the grave these holes had already been filled, in other words they played their role of unknown nature before or during the funeral. Apart from one example, none of the holes contained any finds. Consequently, depositing objects into them could have hardly been the aim when digging these holes.

In the Neolithic cemetery near to the one under discussion, several examples of postholes dug into the corners of the grave pits were observed. Based on their relatively large dimensions, scholars have argued that these might have been the foundations of a house of the dead (Totenhaus). ${ }^{228}$ Although, such constructions above the Iron Age graves are hardly conceivable for the above reasons, similar constructions are not unprecedented in Late Hallstatt Age contexts, nevertheless. Two graves in the Bučany cemetery in today's Slovakia had postholes in the corners, but, as J. Bujna and P. Romsauer argue, the posts in them might have rather served as grave markers. This scenario seems to be more conceivable in the case of the Alsónyék cemetery, although, in two cases (Grave nos. 6 and 8) it is still a problem that both the human remains and the grave goods lay on the filled holes (Fig 9; Fig. 12). The fact however, that the disturbance in Grave nos. 2, 6 and 8 directly affected the area of the upper part of the body might suggest that these graves were in some way marked. Nonetheless, it is noteworthy that on the one hand disturbances were also detected in some of those graves which did not have such postholes, moreover, there is one example, Grave no. 15 , where no sign of secondary manipulation is visible in spite of the burial's two postholes. 


\section{The chronological position of the graves}

It is beyond doubt that in the Alsónyék cemetery the items which allow the most precise dating are the Certosa fibulae. ${ }^{229}$ Certosa brooches of Type V appeared in southern Transdanubia at the end of the 6 th or at the beginning of the next century BC. ${ }^{230}$ In other words, not long after their emergence in northern Italy and Slovenia. ${ }^{231}$ It is worth noting, however, that the case of Grave no. 2 near Beremend is rather exceptional and underlines that based on solely the Certosa fibulae of Type $\mathrm{V}$ none of the burials at Alsónyék can be dated earlier than the beginning of the 5th century BC. It is reasonable to argue, though, that given the resemblance between Grave no. 8 at Alsónyék and Grave no. 2 at Beremend, the former might be dated to the beginning or to the first half of the 5th century BC. The same applies to the chronological position of Grave no. 2 at Alsónyék.

Dating Grave no. 15 is somewhat more problematic. Theoretically, the Certosa brooch of Type $\mathrm{V}$ would allow a relatively early date, but according to Tecco Hvala belt clasps with central bars appear in the graves of the Dolenjska group only during the second half of the Certosa horizon, ${ }^{232}$ in other words in the case of the Alsónyék cemetery, the belt of the grave suggests a slightly later dating. On the other hand, based on the fibula it is justified to assume that the grave in fact precedes most burials of the Szentlonrinc cemetery. As a result, it is reasonable to argue that Grave no. 15 belongs to Horizon 9 of the relative chronological system H. Parzinger proposed, ${ }^{233}$ that is, it is more or less synchronous with the Szárazd and Paks-Gyapa burials as well as the earliest graves of the Szentlörinc cemetery.

Among the graves hitherto unearthed at Alsónyék, Grave no. 1 is most likely the youngest. The iron crossbow fibulae comprise the strongest evidence for this. In the Dolenjsko region the use of this type of fibulae commenced at the beginning of the Negova horizon. ${ }^{234}$ In addition, it is worth mentioning that in the case of the Szentlörinc cemetery they are mostly associated with either Certosa XIIIc and XIIIh type fibulae or brooches of the Early La Tène style. ${ }^{235}$ In other words, a dating to Horizon 9 or even 10 seems reasonable, ${ }^{236}$ i.e. to the second half or end of the 5th century BC.

Lastly, one might even entertain the idea that one Iron Age burial of the Alsónyék cemetery predates the early 5th century BC. Certainly, the evidence for this is very thin, but the possibility is worth taking into consideration. As already mentioned, according to M. Gavranović' perception knives similar to the one found in association with Grave no. 16 resemble the knives of the Urnfield period. ${ }^{237}$ Similar knives came to light from the Statzendorf cemetery, ${ }^{238}$ from graves dated to the $\mathrm{Ha} \mathrm{C} 1-\mathrm{C} 2$ periods. ${ }^{239}$ Furthermore, the specimens found in the Sulmtal

229 DizDAR 2015, 53.

230 ПалавестPA 1984, 67; Parzinger 1989, 124; Teržan 1990, 159; Metzner-Nebelsick 2002, 418; Potrebica DiZDAR 2014, 154; DiZDAR 2019, 323.

231 TERŽAN - ČrEŠNAR 2014, 719.

232 Tecco Hvala 2012, 180.

233 PARZINGER 1989, 107

234 Tecco Hvala 2012, 256.

235 Jerem 1968, Fig. 24,34/3-6; Fig. 25,40/3-4; PArZinger 1989, 107.

236 PARZINGER 1989, 107.

237 Gavranović 2011, 122.

238 ReBAy 2006, 162.

239 REBAY 2006, 289-290. 
cemetery date to the first phase of the site. ${ }^{240}$ The typological analysis of the urn found in this grave would certainly provide valuable information regarding the chronological position of the burial, but unfortunately, this is not possible at this point. It is worth mentioning though that the horizontal knob on the side of the vessel alone does not rule out the possibility that the grave is indeed earlier than the others.

One also has to raise awareness of the possibility that although they are not included in the publication of the Avar Age graves of the site ${ }^{241}$ Graves 3, 4, and, especially, 5 might date to the Migration Period. This also leads us to emphasise for the need for further investigations at the site.

\section{Conclusions}

Ever since the discovery of the Szentlörinc and Beremend cemeteries, these sites has fundamentally shaped our understanding of the Late Hallstatt Age of southern Transdanubia and the southwestern part of the Carpathian Basin. However, they also raised several questions. In my view, the Alsónyék cemetery proved to be essential in answering some of these questions, especially those regarding burial customs. Firstly, it offers an explanation why burials like those found near Beremend, Szárazd and Paks seem to be solitary, isolated graves. In addition, besides the Szentlörinc cemetery this site also proves that the funerary customs, especially the rite of the burials is more diverse than previously thougth. Beyond the insight into the funerary customs of the 5th century $\mathrm{BC}$ which the graveyard has already provided, attention has to be brought to the vast potential this site still has.

Although it is only partially excavated, in terms of the number of burials the Alsónyék site is already the second largest Middle Iron Age cemetery in the region between the Kapos and Sava Rivers. Moreover, the number of graves in the area around the excavated section can certainly still be significantly higher. Future investigations of the site may offer further insight into the characteristics of the layout of the graveyard and the complex social as well as cultural relations of the population who chose to inter their deceased here.

\section{Acknowledgements}

I would like to express my gratitude towards János Gábor Ódor for kindly allowing me to work with this remarkable assemblage. I am also indebted to Márta Vizi, Attila Czövek, and Antal Csiszér for their ernourmus help during my visits to the Wosinszky Mór Museum - Szekszárd. Also, I am deeply grateful for Zoltán Czajlik's guidance and invaluable advices.

This research was supported by the ÚNKP-18-2 New National Excellence Program of the Ministry of Human Capacities.

\section{References}

АнъЕлић, Д. 2017: Налази старијег гвозденог доба у околини Новог Сада (Artefacts from the Early Iron Age in the Vicinity of Novi Sad). Грата за Проучаване Споменика Културе Војводине 30, 32-47. 
АРСЕНИЈЕВИЋ, С. 1998: Покушај синтезе налаза гвозденодобних астрагалоидних појасева. Balcanica $29,7-34$.

АРСенИјевић, С. 2013: Појасне копче из млатег гвозденог доба на тлу западног и централног Балкана. Бања Лука.

Bakarić, L. - Križ, B. - Šoufek, M. 2006: Pretpovijesni jantar i staklo iz Prozora u Lici i Novog Mesta u Dolenjskaj (Prehistoric amber and glass from Prozor in Lika and Novo Mesto in Dolenjska). Zagreb.

Balázs Kovács, S. 2015: A régi Sárköz. A Wosinsky Mór Múzeum Évkönyve 36, 217-298.

BenAc, A. - Čović, B. 1957: Glasinac. Teil II - Die Eisenzeit. Katalog der vorgeschichtlichen Sammlung des Landesmuseums in Sarajevo 2. Sarajevo.

Blečíc Kavur, M. - JašArević, A. 2016: The Known Unknown: New Archaeological „Clothes” of Ritešić. In: Sîrbu, V.-Jevtić, M.-Dmitrović, K.-Ljuština, M. (eds): Funerary Practices of the Bronze and Iron Ages in Central and South-Eastern Europe. Proceedings of the 14th International Colloquium of Funerary Archaeology in Čačak, Serbia, 24th - 27th September 2015. BelgradČačak, 225-236.

БрукнЕР, О. 1959: Халштатска Некропола код Дорослова. Грата за проучаваюе споменика културе у Војводине 3, 5-17.

BRunšmid, J. 1902: Prethistorijski predmeti iz Srijemske Županije. Vjesnik Arheološkog muzeja u Zagrebu 6, 68-86.

Božić D. 2016: Graves from the Certosa Phase in Early Iron Age Barrow 48 at Stična. Prilozi Instituta za arheologiju u Zagrebu 33, 155-170.

Božić D. - Gaspari, A. - Pirkmajer, D. 2020: Poznohalštatska grobova s Kovka nad Hrastnikom v Zasavju (Late Hallstatt burials from Kovk above Hrastnik, in the Zasavje region [central Slovenia]). Arheološki vestnik 71, 499-527. doi: 10.3986/AV.71.18

Bujna, J. - Romsauer, P. 1983: Späthallstatt- und frühlaténezeitliches Gräberfeld in Bučany. Slovenská Archeológia 31, 277-322.

Сносновоwsкi, J. 1985: Die Vekerzug-Kultur. Characteristik der Funde. Warszawa-Kraków.

Chytráček, M. - Golec, M. - Chvojka, O. - MetličKa, M. - Michálek, J. - Novotná, M. - FrolíkovÁ, D. 2017: Jantar starší doby železné a průběh jantarové stezky ve střední Evropě (Bernstein der älteren Eisenzeit und der Verlauf der Bernsteinstraße in Mitteleuropa). Památky archeologické 108, 121-256.

Čović, B. 1956: Ilirska nekropola u Čarakovu (Nécropole illyrienne á tombes plates de Carakovo prés de Prijedor). Glasnik Zemaljskog Muzeja Bosne i Hercegovine u Sarajevu 11, 187-204.

Čović, B. 1987a: Grupa Donja Dolina - Sanski most. In: Gabrovec, S. (ed.): Praistorija fugoslavenskih Zemalja V. Željezno Doba. Ljubljana, 232-286.

Čović, B. 1987b: Srednjobosanska grupa. In: Gabrovec, S. (ed.): Praistorija fugoslavenskih Zemalja V. Željezno Doba. Ljubljana, 481-528.

Dizdar, M. 1999: Željezno doba. In: Dizdar, M.-Iskra-Janošıć, I.-ŠKrivanko, M. K. (eds): Vinkovci u svijetu arheologije: katalog izložbe. Vinkovci, 39-50.

DizDAR, M. 2010: Kantharoi of Autochthonous - "Pannonian" Origin from the La Tène Culture Cemetery in Zvonimirovo, Croatia. In: Berecki, S. (ed.): Iron Age Communities in the Carpathian Basin. Proceedings of the International Colloquium from Târgu Mureş 9-11 October 2009. Bibliotheca Mvsei Marisiensis - Seria Archaeologica 2. Cluj-Napoca, 297-307.

DizdAR, M. 2015: Late Hallstatt Female Grave from Belišce. A Group of Late Hallstatt Finds in the Lower Drava Valley. In: Gutjahr, Ch.-Tiefengraber, G. (eds): Beiträge zur Hallstattzeit am Rande der Südostalpen, Akten des 2. Wildoner Fachgespräches am 10. und 11. Juni 2010 in Wildon/ Stmk. Rahden/Westf., 45-60.

Dizdar, M. 2019: New Late Hallstatt Finds from the Vinkovci Region (Eastern Croatia): A Contribution to the Study of Impacts from the Balkans to the southeastern Carpathian Basin. In: 
Filipović, V.-Bulatović, A.-Kapuran, A. (eds): Зборник Радова у Част 80 г. Живота Растка Bacuћa. (Papers in Honour of Rastko Vasić 80 ${ }^{\text {th }}$ Birthday). Belgrade, 319-344.

Dizdar, M. - Tonc, A. 2018: Not just a belt: Late Iron Age female costume in the south-east Carpathian Basin. Старинар 68, 47-63. doi: 10.2298/STA1868047D

Doвiat, C. 1980: Das hallstattzeitliche Gräberfeld von Kleinklein und seine Keramik. Schild von Steier Beiheft 1. Graz.

Dobiat, C. 1982: Funde aus der Sammlung Mecklenburg. Kleine Schriften aus dem Vorgeschichtlichen Seminar Marburg 12. Marburg.

Dular, J. 1978: Podzemelj. Katalog najdb. Katalogi in Monografije 16. Ljubljana.

DulAR, J. 2003: Halštatske nekropole Dolenjske (Die hallstattzeitlichen Nekropolen in Dolenjska). Opera Instituti archaeologici Sloveniae 6. Ljubljana. doi: 10.3986/9789610502944

Dular, J. - S. Tecco Hvala 2007: South-eastern Slovenia in the Early Iron Age: Settlement - Economy Society (Jugovzhodna Slovenija v starejši želenzni dobi: poselitev, gospodarstvo, družba). Opera Instituti archaeologici Sloveniae 12. Ljubljana.

Ďurkovič, É. 2009: Kora vaskori temető Fertőrákos-Kőhidai dűlőn (Früheisenzeitliches Gräberfeld in Fertőrákos-Kőhidai dűlő). Communicationes Archaeologicae Hungariae, 51-83.

EGG, M. 1986: Italische Helme. Studien zu den ältereisenzeitlichen Helmen Italiens und der Alpen. Monographien des Römisch-Germanischen Museums 11. Mainz.

EGG, M. 1999: Waffenbrüder? Eine ungewöhnliche Bestattung der Frühlatènezeit in Novo mesto in Slowenien. Fahrbuch des Römisch-Germanischen Zentralmuseums Mainz, 46, 317-356.

EGG, M 2006: Anmerkungen zu den Fürstengräbern im Osthallstattkreis. In: CARNAP-BornheIM, CKrausse, D.-Wesse, A. (Hrsg.): Herrschaft, Tod, Bestattung: zu den vor- und frühgeschichtlichen Prunkgräbern als archäologisch-historische Quelle; Internationale Fachkonferenz Kiel 16.-19. Oktober 2003. Universitätsforschungen zur prähistorischen Archäologie 139. Bonn, 41-60.

FeкETE, M. 1985: Rettungsgrabung früheisenzeitlicher Hügelgräber in Vaskeresztes. Acta Archaeologica Acadaemiae Scientiarum Hungaricae 37, 33-78.

FiAlA, F. 1899: Das Flachgräberfeld und die prähistorische Ansiedlung in Sanskimost. Wissenschaftliche Mitteilungen aus Bosnien und der Herzegowina 9, 62-128.

FigleR, A. 2010: Hallstatt-kori halomsírok Nagybarátin (Hallstatt Age Tumuli in Nagybaráti [Győrújbarát]). Arrabona 48, 7-48.

Filipović, V. - Mladenović, O. 2017: Prilog proučavanju članaka astragalnih pojaseva sa teritorije centralne i jugoistočne Evrope (Contribution to the Study of Astragal Belt Segments from the Territory of Central and Southeastern Europe). Prilozi Instituta za arheologiju u Zagrebu 34, 143-184.

Frey, O.-H. 1969: Die Entstehung der Situlenkunst. Studien zur figürlich verzierten Toreutik von Este. Römisch-germanische Forschungen 31. Berlin.

GAÁL, A. 2001: Késő vaskori sír az S-9-es út területéről (Späteisenzeitliches Grab vom Gebiet der Autostraße S9). In: GAÁL, A. (ed.): Tolna megye évszázadai a régészet tükrében. Szekszárd, 27-30.

Gabrovec, S. 1987a: Dolenjska grupa. In: Gabrovec, S. (ed.): Praistorija fugoslavenskih Zemalja V. Željezno Doba. Ljubljana, 29-119.

Gabrovec, S. 1987b: Svetolucijska grupa. In: Gabrovec, S. (ed.): Praistorija fugoslavenskih Zemalja V. Željezno Doba. Ljubljana, 120-150.

GÁL, K. - Molnár, A. 2004: Sé-Doberdó. Az 1998-as és 2001-es ásatások vaskori leletenyaga (Hallstattund Latènezeitliche Siedlungsreste aus Sé, Komitat Vas). Savaria 28, 159-230.

ГАРАШАНИН, М. 1973: Праисторија на тлу Сп. Србије. Београд.

Gaspari, A. - Mlinar, M. 2005: Grave with a machaira from Most na Soči. Last versions of singleedged swords with a bent hilt. Arheološki Vestnik 56, 169-186. 
GÁtı, Cs. 2014: On the Crossroads of Cultures. Cultural and Trade Connections of the Site of Szajk in South Transdanubia. In: BERECKI, S. (ed.): Iron Age Crafts and Craftsmen in the Carpathian Basin. Proceedings of the International Colloquium from Târgu Mureş 10-13 October 2013. Bibliotheca Mvsei Marisiensis - Seria Archaeologica 7. Târgu Mureş, 115-138.

Gavranović, M. 2011: Die Spätbronze- und Früheisenzeit in Bosnien. Universitätsforschungen zur prähistorischen Archäologie 195. Bonn.

GuŠtin, M. - TeržAN, B. 1977: Beiträge zu den vorgeschichtlichen Beziehungen zwischen dem Südostalpengebiet, dem nordwestlichen Balkan und sem südlichen Pannonien im 5. Jahrhundert. In: Markotic, V (ed.): Ancient Europe and the Mediterranean: Studies presented in honour of Hugh Hencken. Warminster, 77-89.

HoRnÁk, M. 2006: Príspevok k historickej interpretácii sklenených korálikov v severovýchodoalpskej oblasti halštatskej kultúry a vo vekerzugskej kultúre (Ein Beitrag zur historischen Interpretation der Glasperlen auf dem Nordostalpengebiet der Hallstattkultur und in der Vekerzugkultur). Studia Historica Nitriensia 13, 37-47.

ILON, G. 2017: Skythische Spiralringe oder Piercings aus West-Transdanubien und ihre Symbolik (Scythian spiral jewellery or piercings from West-Transdanubia and their symbolic meaning). In: HečKovÁ, J. (ed.): Mimoriadne číslo časopisu venované životnému jubilee prof. Petra Romsauera: Sedem Decénií Petra Romsauera. Studia Historica Nitriensia - Supplementum, Nitra, 97-116. doi: 10.17846/SHN.2017.21.S.97-116

JAŠAREvić, A. 2017: Zaboravljeni grobovi iz Donje Doline (The Forgotten Graves from Donja Dolina). Glasnik Zemaljskog Muzeja Bosne i Hercegovine u Sarajevu 54, 7-30.

Jerem, E. 1968: The Late Iron Age Cemetery of Szentlőrinc. Acta Archaeologica Academiae Scientiarum Hungaricae 20, 159-208.

Jerem, E. 1973: Zur Geschichte der späten Eisenzeit in Transdanubien. Späteisenzeitliche Grabfunde von Beremend. Acta Archaeologica Academiae Scientiarum Hungaricae 25, 65-86.

JEREM, E. 1974: Handelsbeiehungen zwsichen der Balkanhalbinsel und dem Karpatenbecken im IV. und V. Jahrhundert v. u. Z. In: ChropovskÝ, B. (ed.): Symposium zu Problemen der jüngeren Hallstattzeit in Mitteleuropa. Bratislava, 229-242.

Jerem, E. 1981: Südliche Beziehungen einiger hallstattzeitlichen Fundtypen Transdanubiens. Materijali Saveza arheoloških društava Jugoslavije 19, 201-220.

JEREM, E. 1987: Die ältesten Körperbestattungen im Osthallstattkreis. Mitteilungen der Österreichischen Arbeitsgemeinschaft für Ur- und Frühgeschichte 37, 91-101.

JEREM, E. 1996: Zur Ethnogenese der Ostkelten - Späthallstatt- und frühlaténezeitliche Gräberfelder zwischen Traisental und Donauknie. In: Jerem, E.-Krenn-Leeb, A.-Neugebauer, J.-W.Urban, O. H. (eds): Die Kelten in den Alpen und an der Donau: Akten des Internationalen Symposiums, St. Pölten, 14.-18. Oktober 1992. Budapest, 91-110.

Jevtić, M. 2016a: Basarabi and Ferigile Finds on the Border Between the Carpathian Basin and Central Balkans. Contributions to the Early Iron Age Chronology. In: Berecki, S. (ed.): Iron Age Chronology in the Carpathian Basin. Proceedings of the International Colloquium from Târgu Mureș, 8-10 October 2015. Bibliotheca Musei Marisiensis - Series Archaeologica 12. Cluj-Napoca, 9-18.

Jevtić, M. 2016b: On frunerary ritual in the princely tumulus in Pilatovići near Požega. In: SîRBu, V.Jevtić, M.-Dmitrović, K.-Ljuština, M. (eds.): Funerary Practices of the Bronze and Iron Ages in Central and South-Eastern Europe. Proceedings of the 14th International Colloquium of Funerary Archaeology in Čačak, Serbia, 24th-27th September 2015. Belgrad-Čačak, 257-270.

JovANOvić, M. 1998: Astragalni pojasevi na području centralnog Balkana i jugoistočne Evrope (Astragaloid Belts in the Region of the Centrals Balkans and Southeast Europas). Рад Музеја Војводине 40, 39-96.

HoRvÁTH, L. 2015: Középső vaskori öntőformák Alsópáhokról (Middle Iron Age Moulds from Alsópáhok). Archaeologiai Értesítő 140, 229-255. doi: 10.1556/0208.2015.140.9 
Kapuran, A. 2013: Late Hallstatt Pottery from North-Eastern Serbia (6th to 4th century BC). Старинар 63, 23-51. doi: 10.2298/STA1363023K

KeLleR, Ch. 2015: Die Rekonstruktion sozialer Gruppen der Hallstattzeit zwischen Enns und Donau. Eine statistische Analyse. Berliner Archäologische Forschungen 14. Berlin.

KemenczeI, T. 2002: Beiträge zur Schmuckmode der Alföld-Gruppe skythischer Prägung (Adatok a szkíta jellegü Alföld-csoport ékszerdivatjához). Folia Archaeologia 49-50, 29-77.

KemenczeI, T. 2009: Studien zu den Denkmälern skythisch geprägter Alföld-Gruppe. Inventarta Praehistorica Hungariae 12. Budapest.

Kemenczei, T. 2010: Funde der skythisch geprägten Alföld-Gruppe in Transdanubien. Folia Archaeologia 54, 101-125.

Klimscha, F. - Blaschke, W. - Thiele, E. 2012: Bemerkungen zu Vorkommen, Verbreitung und Bedeutung überdimensionierter Lanzen der europäischen Eisenzeit. Archäologisches Korrespondenzblatt 42, 351-369.

KMEŤovÁ, P. 2017: Contacts between the Late Hallstatt groups of the Pannonian Basin, the south-east Alpine Hallstatt region and ancient Veneti from the perspective of horse burials In: TREFNÝ, M. - Jennings, B. (eds.): Inter-regional contacts during the first millenium B.C. in Europe. Hradec Králové, 92-117.

Knez, T. 1986: Novo mesto I. Halštatski grobovi (Hallstattzeitliche Gräber). Carniola archaeologica 1. Novo mesto.

Коледин, J. 2012: О једном новијем налазу из гвозденог доба у Срему. Старинар 62, 107-112.

KoRošEc, J. 1943: Noviji neobjavljeni predmeti predpoviestne zbirke (Nekoliko novih nalaza sa gradine "Grad" iznad Semizovca). Glasnik Zemaljskog Muzeja u Sarajevu 54, 51-59.

Kovacsóczky, B. 2017: Alsónyék-Elkerülő út 2. lelőhely avar kori temetője I. (Friedhof des Fundortesin Alsónyék-Umgehungstraße 2. aus der Awarenzeit I.). A Wosinsky Mór Múzeum Évkönyve 39, 95-233.

Kozubová, A. 2013: Pohrebiská vekerzugskej kultúry v chotíne na juhozápadnom Slovensku. Dissertationes Archaeologicae Bratislavenses 1. Bratislava.

Križ, B. - Jereb, M. - TeržAn, B. 2014: Novo mesto-Kandija. In: TeržAn, B. - ČrešNAR, M. (eds.): Absolutno datiranje bronaste in železne dobe na Slovenskem (Absolute Dating of the Bronze and Iron Ages in Slovenia). Katalogi in Monografije 40. Ljubljana, 473-484.

Kromer, K. 1959: Brezje. Halštatske gomile z Brezij pri Trebelnem (Brezje. Hallstättische Hügelgräber aus Brezje bei Trebelno). Arheološki Katalogi Slovenije 2. Ljubljana.

KunteR, K. 1995: Schichtaugenperlen. Glasperlen der vorrömischen Eisenzeit 4. Marburger Studien zur vor- und Frühgeschichte 18. Marburg.

LÁzÁR, J. 1955: Hallstatt-kori tumulusok a Ság-hegy távolabbi környékéről (Hallstattzeitliche Tumuli aus der weiteren Umgebung des Ságberges, Westungarn). Archaeologiai Értesítő 82, 202-211.

Lengyel, I. 1959: A halimbai (Veszprém megye) koravaskori temető (La Cimetière du premier Âge du Fer de Halimba). Archaeologiai Értesitő 86, 159-169.

Majnarić-PAndžıć, N. 2002: Multi-headed „Pins“ of the Donja Dolina Type Revisited. Godišnjak Centra za balkanološka ispitivanja 32, 283-292.

MAJNARIĆ-PANDžIć, N. 2003: Ein späthallstattzeitliches Gräberfeld in Vinkovci (Nordostkroatien) und das Problem eines neuen Phänomens der Pferdausstattung in diesem Gebiet. Germania 81, 481-511.

Marchesetti, C. 1993: Scritti sulla necropoli di S. Lucia di Tolmino (Scavi 1884-1902). Trieste.

MArić, Z. 1964: Donja dolina. Glasnik Zemaljskog Muzeja Bosne i Hercegovine u Sarajevu 19, 5-128.

MARIć, Z. 1971: Die japodischen Nekropolen im Unatal. Wissenschaftliche Mitteilungen des Bosnisch-Herzegowinischen Landesmuseums, A - Archäologie 1, 13-96. 
MARIJAN, B. 1986: Zajednička grobnica željeznog doba iz Vašarovina kod Livna. Glasnik Zemaljskog Muzeja Bosne i Hercegovine u Sarajevu - Arheologija 40/41, 23-38.

MÁrton, L: 1933: A korai La Tene-kultúra Magyarországon (Die Frühlatenezeit in Ungarn). Archaeologia Hungarica 11. Budapest.

Medović, P. 2007: Stubarlija Nekropola Naselja Feudvar kod Mošorina (Bačka). Muzej Vojvodine: Posebna izdanja 20. Novi Sad.

Medović, P. - Medović, I. 2011: Gradina na Bosutu. Naselja starijeg gvozdenog doba. Novi Sad.

MetZner-NeBelsick, C. 2002: Der „Thrako-Kimmerische“ Formenkreis aus der Sicht der Urnenfelder- und Hallstattzeit im südöstlichen Pannonien. Vorgeschichtliche Forschungen 23. Rahden/Westf.

Mithay, S. 1980: A vaszari koravaskori temető és telephely (Gräberfeld und Siedlung von Vaszar aus der Früheisenzeit). Archaeologiai Értesító 107, 53-78.

NAGY, L. 1939: A középrépáspusztai (Veszprém megye) kora-vaskori temető (Das früheisenzeitliche Gräberfeld von Puszta Középrépás [Komitat Veszprém]). Folia Archaeologica 1, 39-57.

Osztás, A. - BÁNffy, E. - ZAlai-GaÁl, I. - Oross, K. - MArton, T. - Somogyi, K. 2013: Alsónyék-Bátaszék: introduction to a major Neolithic settlement complex in south-east Transdanubia. Berichte der Römisch-Germanischen Komission 94, 7-22.

Палавестра, А. 1984: Кнежевски гробови старијег гвозденог доба на централном Балкану. Београд.

Párducz, M. 1955: Le cimetiere halstattien de Szentes-Vekerzug III. Acta Archaeologica Academiae Scientiarum Hungaricae 6, 1-19.

PÁrducz, M. 1966: The Scythian Age Cemetery at Tápiószele. Acta Archaeologica Academiae Scientiarum Hungaricae 18, 43-112.

Parker Pearson, M. 2001: The Archaeology of Death and Burial. Bryan, Texas.

PARzinger, H. 1989: Chronologie der Späthallstatt- und Frühlaténe-Zeit: Studien zu Fundgruppen zwischen Mosel und Save. Quellen und Forschungen zur prähistorischen und provinzialrömischen Archäologie 4. Weinheim.

Patek, E. 1982: Die hallstattzeitlichen Glasperlen Transdanubiens. Savaria 16, 161-180.

PATEK, E. 1993: Westungarn in der Hallstattzeit. Qvellen und Forschungen zur Prähistorie und provincialrömische Archäeologie 7. Weinheim.

Pflug, H. 1988: Korinthische Helme. In: Bottini, A.-von Hase, F.-W.-EgG, M.-Pflug, H.SchaAf, U.-Schauer, P.-Waurick, G.: Antike Helme. Sammlung Lipperheide und andere Bestände des Antikensmuseums Berlin. Monographien des Römisch-Germanischen Museums 14. Mainz, 65-106.

Pilling, Z. - UjváRI, F. 2012: Iron Age Settlement and Cemetery from Szeged-Kiskundorozsma. In: Berecki, S. (ed.): Iron Age Rites and Rituals in the Carpathian Basin. Proceedings of the International Colloquium from Târgu Mureş 7-9 October 2011. Bibliotheca Mvsei Marisiensis - Seria Archaeologica 5. Târgu Mureş, 217-248.

Popović, P. 1996: Early La Tène Between Pannonia and the Balkans. Старинар 47, 105-125.

Potrebica, H. 2008: Contacts between Greece and Pannonia in the Early Iron Age - With Special Concern to the Area of Thessalonica. In: BieHL, P. F.-RAssAmakin, Y. Y. (eds): Import and Imitation in Archaeology. Langenweißbach, 187-212.

Potrebica, H. - Dizdar, M. 2014: Late Hallstatt and Early La Tène Gold and Silver Beads in Southeast Pannonia. In: Gosden, Ch.-Crawford, S.-Ulmschneider, K. (eds): Celtic Art in Europe - Making Connections. Essays in honour of Vincent Megaw on his 80th birthday. Oxford, 152-158. doi: 10.2307/j.ctvh1dqs8.21

Primas, M. 2007: Spinnwirtel im Grab - zum Symbolgehalt einer Beigabe. In: BLEČIĆ, M.-ČREŠNAR, M.HäNSEL, B. (eds): Scripta praehistorica in honorem Biba Teržan. Situla 44. Ljubljana, 301-312.

Radimsky, R. 1895: Die Nekropole von Jerezine in Pritoka bei Bihać. Wissenschaftliche Mitteilungen aus Bosnien und der Herzegowina 3, 60-218. 
Rassmann, K. - Mischka, C. - Furholt, M. - Ohlrau, R. - Radloff, K. - Winkelmann, K. - Serlegi, G. Marton, T. - Osztás, A. - Oross, K. - BÁnffy, E. 2015: Large Scale Geomagnetic Prospection on Neolothic Sites in Hungary 1. Hungarian Archaeology 2015 Spring, http://files.archaeolingua. hu/2015TA/Rassmann_E15TA.pdf (last access: 09.02.2021).

Rebay, K. 2006: Das hallstattzeitliche Gräberfeld von Statzendorf in Niederösterreich. Möglichkeiten und Grenzen der Interpretation von Sozialindexberechnungen. Universitätsforschungen zur prähistorischen Archäologie 135. Bonn.

Rebay-Salisbury, K. 2016: The Human Body in Early Iron Age Central Europe. London-New York. doi: $10.4324 / 9781315277233$

Rustoru, A. 2012. The Celts and Indigenous Populations from the Southern Carpathian Basin. In: Berecki, S. (ed): Iron Age Rites and Rituals in the Carpathian Basin. Proceedings of the International Colloquium from Târgu Mureş 7-9 October 2011. Bibliotheca Mvsei Marisiensis - Seria Archaeologica 5. Târgu Mureş, 357-390.

Schwellnus, F. 2011: Die Siedlung von Sopron-Krautacker (Westungarn) in der späten Hallstatt- und frühen Latènezeit. Archäologischer Korrespondenzblatt 41, 359-373.

StARE, V. 1965: Železnodobne gomile na Vinkovem vrhu (Eisenzeitliche Grabhügel auf Vinkov vrh). Arheološki vestnik 15-16, 215-257.

Stare, V. 1973a: Prazgodovina Šmarjete. Katalogi in monografije 10. Ljubljana.

Stare, V. 1973b: Gomile pod Koriti na Dolenjskem (Hügelgräber bei Korita in Dolenjsko). Arheološki Vestnik 24, 744-765.

Szabó, M. 2012: Celtes et Pannons dans le Sud-Est de la Transdaubie. Acta Archaeologica Academiae Scientiarum Hungaricae 63, 351-366. doi: 10.1556/AArch.63.2012.2.4

Tecco Hvala, S. 2012: Magdalenska gora. Družbena struktura in grobni rituali železnodobne skupnosti (Magdalenska gora. Social structure and burial rites of the Iron Age community). Opera Instituti Archaeologici Sloveniae 26. Ljubljana. doi: 10.3986/9789612546007

Tecco Hvala, S. 2017: Molnik pri Ljubljani v železni dobi (The Iron Age site at Molnik near Ljubljana). Opera Instituti Archaeologici Sloveniae 36. Ljubljana 2017. doi: 10.3986/9789610503750

Tecco Hvala, S. - Dular, J. - Kocuvan, E. 2004: Železnodobne gomile na Magdalenski Gora (Eisenzeitliche Grabhügel auf der Magdalenska Gora). Katalogi in Monografije 36. Ljubljana.

TeržAn, B. 1977a: Certoska fibula (Die Certosafibel). Arheološki vestnik 27, 317-536.

TeRžAn, B. 1977b: O horizontu bojevniških grobov med Padom in Donavo v 5. in 4. stol. pr. n. št. (Horizon of Warrior Tombs found in the Fifth and Fourth Centuries B.C. in the Territory between the Po and the Danube). In: Guštin, M.-Grosman, D.-TušEK, M. L. (eds): Keltske študije. Posavski muzej Brežice 4. Brežice, 9-21.

TERŽAN, B. 1986: Zur gesellschaftsstruktur während der älteren Hallstattzeit im Ostalpen-Westpannonischen Gebiet. In: Töвöк, L. (ed.): Hallstatt Kolloquium Veszprém, 1984. Antaeus - Beiheft 3. Budapest, 227-244.

TeržAn, B. 1990: Starejša železna doba na slovenskem Štajerskem (The early iron age in Slovenian Styria). Katalogi in monografija 25. Ljubljana.

TERŽAN, B. 1994: Überlegungen zum sozialen Status des Handwerkers in der frühen Eisenzeit Südosteuropas. In: Dobiat, C. (ed): Festschrift für Otto-Herman Frey zum 65. Geburtstag. Marburger Studien zur Vor- und Frühgeschichte 16. Marburg, 659-669.

TeržAn, B. 1997: Heros der Hallstattzeit. Beobachtungen zum Status an Gräbern um das Caput Adriae. In: Becker, C.-Dunkelmann, M.-L.-Metzner-Nebelsick, C. (eds): Chronos. Beiträge zur prähistorischen Archäologie zwischen Nord- und Südosteuropa. Festschrift für Bernhard Hänsel. Internationale Archäologie - Studia honoraria 1. Espelkamp, 653-669.

TeRŽAn, B. 1998: Auswirkungen des skythisch geprägten Kulturkreises auf die hallstattzeitlichen Kulturgruppen Pannoniens und des Ostalpenraumes. In: HäNSEL, B.-MAChNiK, J. (eds): Das Kar- 
patenbecken und die osteuropäische Steppe. Prähistorische Archäologie in Südosteuropa 12. Südosteuropa-Schriften 20. Rahden/Westf., 511-560.

TeržAn, B. - ČreŠnAR, M. 2014: Poskus absolutnega datiranja starejše železne dobe na Slovenskem (Attempt at an Absolute Dating of the Early Iron Age in Slovenia). In: TeržAN, B.-ČrEŠNAR, M. (eds): Absolutno datiranje bronaste in železne dobe na Slovenskem (Absolute Dating of the Bronze and Iron Ages in Slovenia). Katalogi in monografije 40. Ljubljana, 703-724.

Teržan, B. - Lo Schiavo, F. - Trampuž-Orel, N. 1985: Most na Soči (S. Lucia) II. Szombathyjeva izkopavanja (die Ausgrabungen von J. Szombathy). Catalogi et Monographiae 23. Ljubljana.

Todorović, J. 1965: Ein Beitrag zur stilistischen und zeitlichen Bestimmung der astragaloiden Gürtel in Jugoslawien. Archaeologia Iugoslavica 5-6, 45-48.

TöröK, Gy. 1950: Pécs-jakabhegyi földvár és tumulusok (The earthwork and tumuli of Pécs-Jakabhegy). Archaeologiai Értesitó 77, 4-9.

ТрАјковић, Д. 2008: Ђепфелд. Некрополе старијег гвозденог доба код Дорослова (Đepfeld: Early Iron Age Necropolis at Doroslovo). Sombor.

TruhelKa, Č. 1904: Der vorgeschichtliche Pfahlbau im Savebette bei Donja Dolina. Wissenschaftliche Mitteilungen aus Bosnien und der Herzegowina 9, 3-170.

Turk, P. 2009: Belt hook. In: Turk, P.-Istenič, J.-Knific, T.-NABergoj, T. (eds): The Ljubljanica a River and its Past. Ljubljana, 242-243.

VAsić, R. 1989: Jedan prilog proucavanju Sremske grupe (Une Contribution a l'étude du Grupe de Syrmie). Godišnjak Centra za balkanološka ispitivanja 25, 103-113.

ВАсић, Р. 2009: Белешке о Гласиницу - хронологија кнежевских гробова (Notes on Glasinac - the Chronology of Princely Graves). Старинар 59, 109-118. doi: 10.2298/STA0959109V

ВАСиљевит, М. 1976: Налази старијег гвозденог доба у Шапцу. Старинар 27, 167-174. doi: 10.5652/ kokusaikeizai.1976.167

Vulpe, A. 1967: Necropola hallstattiana de la Ferigile. Monografie arheologică. Biblioteca de arheologie 11. Bucuresti.

Zalai-GaÁl, I. - Osztás, A. - Köhler, K. 2012: Totenbrett Oder Totenhütte? Zur Struktur der Gräber der Lengyel-Kultur mit Pfostenstellung in Südtransdanubien. Acta Archaeologica Academiae Scientiarum Hungaricae 63, 69-116. doi: 10.1556/AArch.63.2012.1.3 
